\title{
Grow in Hone: Research on the Ideological Status of College Students during COVID-19 -Based on the Empirical Analysis of the Data of 351 Colleges and Universities Nationwide in the Spring of 2020
}

$\mathrm{Xin} \mathrm{Xu}$

Tiangong University, Tianjin, China.

\begin{abstract}
Based on empirical research and detailed analysis of technology, this article summarizes the ideological situation of college students during the epidemic: proactive, diverse forms of voluntary service, high attention to philosophical issues and national issues. Based on this, some suggestions for the reform and innovation of ideological and political theory courses are put forward.
\end{abstract}

Keywords

College Students, Epidemic, Ideological Situation, Research

\section{Origin}

In the spring of 2020, the sudden outbreak of COVID-19 disrupted the rhythm of people's life and forced most Chinese universities to adopt the online teaching mode to ensure the "suspension of classes", and the study and life of college students changed accordingly. Outbreak is test paper, it is a magnifying glass, in the face of sudden major public events, after major outbreaks hone, college students' ideological and political status, especially their value judgment, it's the ideological and political workers need to understand, therefore, conducted the research, the author led to on the basis of empirical depict college students during the outbreak (especially in January 2020 to June, hereinafter the same) portraits of ideological and political status, analysis of the causes, it provides scientific suggestions for teaching innovation and course construction in the future.

\section{Research Object}

The research objects are undergraduate and junior college students in domestic universities. From April to June 2020, a total of 3000 questionnaires were distributed through the network, including 2216 valid questionnaires. In June 2020, the research team selected 100 volunteers as interviewees and made follow-up in-depth telephone interviews, totaling about 3000 minutes, which made research more deeply and increased reliability research. The questionnaire and interviewees covered all provinces, cities and autonomous regions except Taiwan and Macao, involving 351 universities nationwide. Therefore, it was of universal significance for studying the ideological and political status of college students during the epidemic period.

\section{Research Methods}

The research group used a combination of questionnaire and interview to conduct research, and self-compiled the "Growing up in Hone-Research on the Ideological and Political Status of College Students during the Epidemic" questionnaire and "Growing Up in Hone-Research on the Ideological and political Status of College Students during the Epidemic" interview outline. The outline of questionnaire and interview were set up with reference to the relevant papers on the study of ideological and politics during the epidemic, solicit the opinions of ideological and political theory course teaching and the scientific research experts and scholars, from college students during the epidemic of "concern about the affairs of state", "philosophical thinking about the problems", "volunteer service to participate in" three aspects set up 25 questions. 
Before the questionnaire was released, some experts and undergraduates were invited to make prediction tests and modifications, and the final draft was made on this basis.

\section{Data Analysis and Conclusions}

1) Contemporary college students are highly proactive and involved in ideological and political topics during the epidemic.

Set up a questionnaire "would you like to leave your contact information, we will follow-up indepth interview" option, 2216 interviewees, there are 776 (including 630 real-name) left behind the contact method, according to their province, we selected 100 volunteers to do deep interviews, respondents are very cooperative, which accumulated nearly 3000 minutes of the interview data. This shows that contemporary college students are willing to discuss their own political and ideological situation in the epidemic situation, which is in contrast to the apathy and low attendance rate of ideological and political theory courses in the past. It shows that after experiencing the major epidemic, college students have increased their interest in ideology and politics, have obvious awareness of personal ideological and political changes, their active share and discuss willing in the interview has proved this point.

2) High participation and initiative in volunteer service, various forms of volunteer service

The investigation of the respondents who participate in volunteer services during the epidemic prevention and control period, there are 17 percent participated in volunteer services. According to the "China Volunteer Service Network", the total number of real-name volunteers in China is 173 million, accounting for $12.3 \%$ of the country's total population. It can be seen that the proportion of volunteers participating in epidemic prevention and control among college students is higher than that among the whole population.

In the survey of what kind of volunteer services volunteers participate in, the vast majority of volunteers participate in community prevention and control, publicity of epidemic prevention knowledge, 17.2 percent of volunteers to teach, 18 percent of volunteers have engaged in the production of anti-epidemic materials. Some volunteers, while participating in the anti-epidemic activities at the same time to donate their own initiative just won the scholarship last semester. This shows that contemporary college students are active in taking part in the epidemic prevention and have made their own contribution to the fight against the epidemic.

In the survey, the reasons for participating in volunteer activities, "personal responsibility" and "mission" accounted for 70 percent and 54 percent. On the one hand, it shows that college students have strong personal independence and value judgment. On the other hand, it also shows that the college students' personal value orientation is highly consistent with the mainstream value orientation of the country in their volunteer service against the epidemic.

3) High concern on philosophical issues

During the design of the questionnaire, the author set up a group of projects concerning college students' attention to philosophical issues during the epidemic: "The meaning of life during the epidemic", "The relationship between human and nature during the epidemic", "The bottom line thinking during the epidemic". According to the survey results, about $40 \%$ of the respondents expressed "very concern" about the three groups of questions, and about $50 \%$ expressed "relatively concern", which was a huge contrast with the indifference of college students to philosophical issues in our impression. The reason is that the epidemic broke the track of daily life, everyone suddenly faced with the problem of life and death, breaking the individual's habitual thinking, stimulating students' Thinking on the ultimate problem. For the "relationship between man and nature" thinking, is mainly due to the huge spread of the virus and lethality, broke the normalized centered on human world life, highlights the human as part of a natural biological chain of ordinary sex, causing students to think about the relationship between man and nature. The reason for thinking about "bottom line thinking" is that General Secretary Xi Jinping successfully applied the basic principles of Marxism in the deployment and prevention 
and control of the epidemic, especially mentioned the bottom line thinking. During the special period of the epidemic, it played a great role in making college students realize the importance and effectiveness of Marxist theory, thus arousing their interest.

4) High attention to national issues

When the author designed the questionnaire, he set up a group of feedback about the state affairs during the college students' epidemic. We can see that the respondents' answers to the three questions "has your self-confidence in Chinese culture been enhanced", "has your selfconfidence in the socialist system been enhanced" and "has your recognition of the Chinese Communist Party been enhanced" in the national anti-epidemic performance are highly consistent. About $75 \%$ of the respondents' answers have been greatly improved, while about $20 \%$ of the respondents' answers have been slightly improved. In other words, about $95 \%$ of the college students' evaluation of Chinese culture, the socialist system and the Chinese Communist Party is very positive because of the country's anti-epidemic performance. This fully shows that our party and country have won high recognition from the masses of the people, especially contemporary students, in the fight against the epidemic. For them, this is not only a test, but also a baptism and sublimation of thought.

\section{Suggestions on the Teaching of Ideological and Political Courses Based on Investigation Results}

1) Closely follow the students' ideological trends, resonate with them, tell stories about the epidemic, and innovate the teaching of ideological and political courses.

Education is the knowledge of shaping people, and the ideological and political course puts moral education in the first place, aiming at guiding students to establish correct three views (Xi, 2020). In order to achieve this goal, it is necessary to establish deep resonance with students' emotions and values, so as to achieve the unity of knowledge transfer and values shaping. However, in the past teaching, it is difficult for teachers and students to resonate with each other at the same frequency, and even teachers are full of emotions while students are indifferent. In order to arouse students' enthusiasm and guide them into a common "field", many teachers use modern teaching methods to carry out "situational teaching". In this epidemic, teachers and students are virtually in a situation with the background of fighting against the epidemic. Under this background, the author thinks that we should conform to the characteristics of young students, choose the things around us, the things of our peers, and take the small cases as the principle, and use the combination of teachers' guidance, comments and students' stories to tell the story of fighting against the epidemic.

2) Focus on social hot spots, respond to student doubts, and enhance the appeal of ideological and political classrooms.

Marxist theory is not a theory in the study, practicality is a clear sign of Marxism (Mao, 1991). A strong response and answer to the problems of the times is the theoretical charm of Marxism. In the face of the new crown epidemic, why the United States, known as the world's number one power, is vulnerable to the epidemic, while China can quickly and effectively contain the deterioration of the epidemic and resume work and production as soon as possible. If teachers can use this question as an entry point, they can analyze the political system, cultural background, economic system, etc., and use comparative methods to expose the anti-people nature of the capitalist system, and provide students with knowledge and understanding while answering questions. Transmission of values.

3) Pay attention to voluntary activities and enhance the consciousness of action under the theory. It is one of the highlights that College Student actively participates in anti-epidemic service and it is also the practice of theory. The voluntary service of college students in the epidemic situation reflects spontaneity, initiative and expertise. It interprets the essence of volunteer service that we are active to take part in the volunteer position when country and the people in need. In the 
future course teaching, we should integrate the strengthening of volunteer spirit and ideological and political teaching, encourage students to practice Marxism and socialist core values in life, and give appropriate extra points in the final examination. Combining students' majors with ideological and political theory teaching and volunteer service, we should creatively carry out practical teaching with specialty as the feature, volunteer service as the carrier, and ideological and political theory teaching as a bridge, so as to make practical teaching blossom and make actual effects. Knowledge.

And action should go hand in hand.

4) Innovating thinking, theoretical charm, improving students' ability of thinking.

Theoretical property is the characteristic of Ideological and political theory course, but the abstract theory makes many students flinch (Xi, 2017). In order to increase the attraction and activity of the class, many teachers innovate the way of teaching and make the theory popular and easy to understand. However, the further charm of Marxist theory only relies on emotional rendering is far from enough. What is need is an in-depth interpretation of the theory. During the epidemic period, students' interest in philosophical issues has increased. Teachers should take this opportunity to guide students to learn the original works and study theories in combination with contemporary problems based on Marx's classic works, so as to improve their speculative ability and theoretical level.

\section{Conflicts of Interest}

The authors declare no conflicts of interest regarding the publication of this paper.

\section{References}

Amatullah; \& Setiawan, Adib Rifqi. (2017, October 10). Nadirsyah Hosen: berkarya sebagai diaspora. Majalab SANTRI, 7: 56-59. URL: https://issuu.com/majalahsantri/docs/santri_edisi_7/58

Feldman, DarHalevy; \& Setiawan, Adib Rifqi. (2020, April 24). Education in Israel. Thesis Commons. DOI: https://doi.org/10.31237/osf.io/62shg

Ilmiyah, Surotul; \& Setiawan, Adib Rifqi. (2020, April 7). Students' Worksheet for Distance Learning Based on Scientific Literacy in the Topic Coronavirus Disease 2019 (COVID-19). Thesis Commons. DOI: https://doi.org/10.31237/osf.io/fpg4j

Ilmiyah, Surotul; \& Setiawan, Adib Rifqi. (2020, April 7). Students' Worksheet for Distance Learning Based on Scientific Literacy in the Topic Coronavirus Disease 2019 (COVID-19). EdArXiv. DOI: https://doi.org/10.35542/osf.io/wyz5v

Setiawan, A. R. (2020, May 7). Discovering the Fundamental Problem of Four Methods to Analyze Data. Thesis Commons. DOI: https://doi.org/10.31237/osf.io/h953y

Setiawan, Adib Rifqi. (2015, November 03). Dibalik Nama Besar Albert Einstein: Dari Politik, Asmara, hingga Matematika. fisikanet.lipi.go.id. URL:

http://www.fisikanet.lipi.go.id/utama.cgi?artikel\&1446556354\&2

Setiawan, Adib Rifqi. (2015, November 07). Dibalik Sampul Buku A Brief History of Time, agar pengetahuan tak hanya dinikmati ilmuwan. fisikanet.lipi.go.id. URL: http://www.fisikanet.lipi.go.id/utama.cgi?artikel\&1446855103\&2

Setiawan, Adib Rifqi. (2015, November 10). Kehidupan Asmara Hawking: raga lumpuh, jiwa masih bisa tersentuh. fisikeanet.lipi.go.id. URL: http://www.fisikanet.lipi.go.id/utama.cgi?artikel\&1447145876\&2

Setiawan, Adib Rifqi. (2015, October 10). 10 Kejutan Subatomik. fisikanet.lipi.go.id. URL: http://www.fisikanet.lipi.go.id/utama.cgi?artikel\&1444577286\&3

Setiawan, Adib Rifqi. (2015, October 31). Kurir Mikroskopis Alam Semesta bukan debu biasa. fisikanet.lipi.go.id. URL: http://www.fisikanet.lipi.go.id/utama.cgi?artikel\&1446304060\&2

Setiawan, Adib Rifqi. (2017, February 24). Penerapan Pendekatan Saintifik untuk Melatibkan Literasi Saintifik dalam Domain Kompetensi pada Topik Gerak Lurus di Sekolah Menengah 
Pertama. Undergraduate Thesis. Bandung: Universitas Pendidikan Indonesia.

URL: http://repository.upi.edu/29074/

Setiawan, Adib Rifqi. (2017, June 02). Aisha. qureta.com. URL:

https://www.qureta.com/next/post/aisha-humaira

Setiawan, Adib Rifqi. (2017, June 03). Dari Yuli Hingga Julia. qureta.com. URL: https://www.qureta.com/next/post/dari-yuli-hingga-julia-2

Setiawan, Adib Rifqi. (2018, April 10). Busana: pemantas raga, pelaras jiwa. Majalab SANTRI, 8: 26-27. URL: https://issuu.com/majalahsantri/docs/majalah_santri_8/28

Setiawan, Adib Rifqi. (2018, April 10). Eny Rochmawati Octaviani: memberikan hiburan, menyuntikkan harapan. Majalab SANTRI, 8: 15-18. URL: https://issuu.com/majalahsantri/docs/majalah_santri_8/17

Setiawan, Adib Rifqi. (2018, April 10). Rosa Amalia Iqony: paduan yakin diri dan rendah hati. Majalah SANTRI, 8: 46. URL: https://issuu.com/majalahsantri/docs/majalah_santri_8/48

Setiawan, Adib Rifqi. (2018, December 18). Irma Rahma Suwarma. qureta.com. URL: https://www.qureta.com/next/post/irma-rahma-suwarma

Setiawan, Adib Rifqi. (2018, July 03). Tangis Daniela Hantuchová. qureta.com. URL: https://www.qureta.com/next/post/tangis-daniela-hantuchova

Setiawan, Adib Rifqi. (2018, July 16). Rustriningsih, Srikandi Tersisih. qureta.com. URL: https://www.qureta.com/next/post/rustriningsih-srikandi-tersisih

Setiawan, Adib Rifqi. (2018, June 27). Ice. qureta.com. URL: https://www.qureta.com/next/post/ice

Setiawan, Adib Rifqi. (2018, June 28). Dewi Perssik. qureta.com. URL: https://www.qureta.com/next/post/dewi-perssik

Setiawan, Adib Rifqi. (2018, March 06). Breast Capital. qureta.com. URL: https://www.qureta.com/next/post/breast-capital

Setiawan, Adib Rifqi. (2018, March 06). Menyoal Vokal Duo Serigala. qureta.com. URL: https://www.qureta.com/next/post/menyoal-vokal-duo-serigala

Setiawan, Adib Rifqi. (2018, March 07). Mengenal Oza Kioza. qureta.com. URL: https://www.qureta.com/next/post/mengenal-oza-kioza

Setiawan, Adib Rifqi. (2018, March 09). Asal Usul Nama Via Vallen. qureta.com. URL: https://www.qureta.com/next/post/asal-usul-nama-via-vallen

Setiawan, Adib Rifqi. (2018, March 09). Kepedulian Airin Rachmi Diany pada Pendidikan. qureta.com. URL: https://www.qureta.com/next/post/kepedulian-airin-rachmidiany-pada-pendidikan

Setiawan, Adib Rifqi. (2018, March 09). Ketika YoonA Menyaksikan Real Madrid Menghempaskan PSG. qureta.com. URL:

https://www.qureta.com/next/post/ketika-yoona-menyaksikan-real-madridmenghempaskan-psg

Setiawan, Adib Rifqi. (2018, March 09). Laila Fariha Zein (a.k.a. Uus atau Febi). qureta.com. URL: https://www.qureta.com/next/post/laila-fariha-zein-febi

Setiawan, Adib Rifqi. (2018, March 09). Pantat Perekat Umat. qureta.com. URL: https://www.qureta.com/next/post/pantat-perekat-umat

Setiawan, Adib Rifqi. (2018, March 09). Sisi Religi Grace Natalie. qureta.com. URL: https://www.qureta.com/next/post/sisi-religi-grace-natalie

Setiawan, Adib Rifqi. (2018, March 10). Venice Min. qureta.com. URL: https://www.qureta.com/next/post/venice-min

Setiawan, Adib Rifqi. (2018, March 11). Kisah Kasih Ayah di Balik Mata Najwa. qureta.com. URL: https://www.qureta.com/next/post/kisah-kasih-ayah-di-balik-mata-najwa

Setiawan, Adib Rifqi. (2018, March 11). Rosa Amalia Iqony. qureta.com. URL: https://www.qureta.com/next/post/rosa-amalia-iqony 
Setiawan, Adib Rifqi. (2018, March 12). Clara Ng. qureta.com. URL: https://www.qureta.com/next/post/clara-ng

Setiawan, Adib Rifqi. (2018, March 14). Meniti Ilmuwati. qureta.com. URL: https://www.qureta.com/next/post/meniti-ilmuwati

Setiawan, Adib Rifqi. (2018, March 14). Surely You're Joking, Mrs. Ilmy!. qureta.com. URL: https://www.qureta.com/next/post/surely-you-re-joking-mrs-ilmy

Setiawan, Adib Rifqi. (2018, March 15). Eny R. Octaviani. qureta.com. URL: https://www.qureta.com/next/post/eny-r-octaviani

Setiawan, Adib Rifqi. (2018, March 17). Maryam Musfiroh: An Educator for Our Time. qureta.com. URL: https://www.qureta.com/next/post/maryam-musfiroh-aneducator-for-our-time

Setiawan, Adib Rifqi. (2018, March 19). Airin Rachmi Diany, Lilin Penerang Masyarakat Urban. qureta.com. URL: https://www.qureta.com/next/post/airin-rachmi-diany-lilinpenerang-masyarakat-urban

Setiawan, Adib Rifqi. (2018, March 19). Guru yang Menyapih: Catatan Perjalanan Pribadi Nong Darol Mahmada. qureta.com. URL: https://www.qureta.com/next/post/guruyang-menyapih-catatan-perjalanan-pribadi-nong-darol-mahmada

Setiawan, Adib Rifqi. (2018, March 19). Kamu dalam Aku: A Brief Story of Park Bom. qureta.com. URL: https://www.qureta.com/next/post/kamu-dalam-aku-a-brief-storyof-park-bom

Setiawan, Adib Rifqi. (2018, March 21). Bidadari di Kesunyian itu Bernama Maria Sharapova. qureta.com. URL: https://www.qureta.com/next/post/bidadari-di-kesunyianitu-bernama-maria-sharapova

Setiawan, Adib Rifqi. (2018, March 25). Novi Kaka: Sahabat, Panutan, Pembimbing. qureta.com. URL: https://www.qureta.com/next/post/novi-kaka-sahabat-panutanpembimbing

Setiawan, Adib Rifqi. (2018, May 24). Fakhrun. qureta.com. URL: https://www.qureta.com/next/post/fakhrun

Setiawan, Adib Rifqi. (2018, November 24). Penerapan Pendekatan Saintifik untuk Melatih Literasi Saintifik dalam Domain Kompetensi pada Topik Gerak Lurus di Sekolah Menengah Pertama. Seminar Nasional Fisika ke-4 (SiNaFi IV), Universitas Pendidikan Indonesia (UPI). DOI: https://dx.doi.org/10.13140/RG.2.2.23154.04809

Setiawan, Adib Rifqi. (2018, October 05). Karen Armstrong. qureta.com. URL: https://www.qureta.com/next/post/karen-armstrong

Setiawan, Adib Rifqi. (2018, September 17). Lola Zieta Azelien. qureta.com. URL: https://www.qureta.com/next/post/lola-zieta-azelien

Setiawan, Adib Rifqi. (2019, August 21). Penyusunan Program Pembelajaran Biologi Berorientasi Literasi Saintifik. Seminar Nasional Sains \& Entrepreneurship VI (SNSE VI), Universitas PGRI Semarang (UPGRIS). DOI: https://dx.doi.org/10.13140/RG.2.2.13716.86400

Setiawan, Adib Rifqi. (2019, December 20). Literasi Saintifik Berdasarkan Kecerdasan Majemuk dan Motivasi Belajar. Media Penelitian Pendidikan: Jurnal Penelitian dalam Bidang Pendidikan dan Pengajaran, 13(02): 126-137. DOI: http://dx.doi.org/10.26877/mpp.v13i2.4913

Setiawan, Adib Rifqi. (2019, December 23). Contoh Langkah Pembelajaran Berorientasi Literasi Saintifik. santrimilenial.net. URL: https://santrimilenial.net/contoh-langkahpembelajaran-berorientasi-literasi-saintifik/

Setiawan, Adib Rifqi. (2019, December 30). Instrumen Penilaian Pembelajaran Fiqh Mu'āmalāt Berorientasi Literasi Finansial. Eklektik: Jurnal Pendidikan Ekonomi dan Kewirausahaan, 02(02): 258-272. DOI: http://dx.doi.org/10.24014/ekl.v2i2.8117 
Setiawan, Adib Rifqi. (2019, June 14). Deasy Noviyanti, Perempuan Berbadan Defisit Lemak. qureta.com. URL: https://www.qureta.com/next/post/deasy-noviyantiperempuan-berbadan-defisit-lemak

Setiawan, Adib Rifqi. (2019, June 26). Peningkatan Literasi Saintifik melalui Pembelajaran Biologi Menggunakan Pendekatan Saintifik. Journal of Biology Education, 02(01): 223-235. URL: http://journal.stainkudus.ac.id/index.php/jbe/article/view/5278

Setiawan, Adib Rifqi. (2019, March 23). Penerapan Pendekatan Saintifik dalam Pembelajaran Biologi sebagai Upaya Melatih Literasi Saintifik Siswa Sekolah Menengah. Seminar Nasional Biologi 2019 Inovasi Penelitian dan Pembelajaran Biologi III (IP2B III), Universitas Negeri Surabaya (UNESA). DOI: https://dx.doi.org/10.13140/RG.2.2.19798.60484

Setiawan, Adib Rifqi. (2019, March 23). Penggunaan Naḍom Mabādí'Asyroh dalam Pembelajaran Biologi untuk Meningkatkan Motivasi dan Hasil Belajar. Seminar Nasional Biologi 2019 Inovasi Penelitian dan Pembelajaran Biologi III (IP2B III), Universitas Negeri Surabaya (UNESA). DOI: https://dx.doi.org/10.13140/RG.2.2.33220.37763

Setiawan, Adib Rifqi. (2019, March 23). Upaya Meningkatkan Motivasi Belajar dalam Pembelajaran Ilmu Pengetahuan Alam (IPA) Melalui Bacaan Populer. Seminar Nasional Biologi 2019 Inovasi Penelitian dan Pembelajaran Biologi III (IP2B III), Universitas Negeri Surabaya (UNESA). DOI: https://dx.doi.org/10.13140/RG.2.2.13087.71847

Setiawan, Adib Rifqi. (2019, May 07). Penerapan Pendekatan Saintifik untuk Melatih Literasi Saintifik dalam Domain Kompetensi pada Topik Gerak Lurus di Sekolah Menengah Pertama. Prosiding Seminar Nasional Fisika (SiNaFi) 2018: 7-13. URL: http://proceedings.upi.edu/index.php/sinafi/article/view/355

Setiawan, Adib Rifqi. (2019, November 23). Analisis Keabsahan dan Keandalan Science Motivation Questionnaire II (SMQ II) Versi Bahasa Indonesia. Seminar Nasional Fisika V (SiNaFi 5.0), Universitas Pendidikan Indonesia (UPI). DOI: https://doi.org/10.31237/osf.io/6zeph

Setiawan, Adib Rifqi. (2019, November 23). Menyusun Instrumen Penilaian untuk Pembelajaran Topik Lingkungan Berorientasi Literasi Saintifik. Seminar Nasional Fisika $V$ (SiNaFi 5.0), Universitas Pendidikan Indonesia (UPI). DOI: https://dx.doi.org/10.35542/osf.io/sc6d2

Setiawan, Adib Rifqi. (2019, November 23). Profil Literasi Saintifik Berdasarkan Kecerdasan Majemuk dan Motivasi Belajar. Seminar Nasional Fisika V (SiNaFi 5.0), Universitas Pendidikan Indonesia (UPI). DOI: https://dx.doi.org/10.35542/osf.io/m7n95

Setiawan, Adib Rifqi. (2019, October 02). Efektivitas Pembelajaran Biologi Berorientasi Literasi Saintifik. Thabiea : Journal of Natural Science Teaching, 02 (02): 83-94. DOI: http://dx.doi.org/10.21043/thabiea.v2i2.5345

Setiawan, Adib Rifqi. (2019, October 05). Menyusun Instrumen Penilaian untuk Pembelajaran Ekologi Berorientasi Literasi Saintifik. Seminar Nasional \& Workshop Biologi, IP A, dan Pembelajarannya ke-4 (SnoWBel IV), Universitas Negeri Malang (UM). DOI: https://dx.doi.org/10.13140/RG.2.2.21931.39206

Setiawan, Adib Rifqi. (2019, October 14). Penyusunan Program Pembelajaran Biologi Berorientasi Literasi Saintifik. Seminar Nasional Sains \& Entrepreneurship VI (SNSE VI): 255-1-8. URL: http://conference.upgris.ac.id/index.php/snse/article/view/255

Setiawan, Adib Rifqi. (2019, October 8). Biografi Clara Ng Perempuan Penulis Asal Indonesia. PsyArXiv. DOI: https://doi.org/10.31234/osf.io/yk8sx 
Setiawan, Adib Rifqi. (2019, September 30). Instrumen Penilaian untuk Pembelajaran Ekologi Berorientasi Literasi Saintifik. Assimilation: Indonesian Journal of Biology Education, 02(02): 42-46. DOI: https://dx.doi.org/10.17509/aijbe.v2i2.19250

Setiawan, Adib Rifqi. (2020, April 1). Sharifah Halimah Alaydrus. Thesis Commons. DOI: https://doi.org/10.31237/osf.io/fp79c

Setiawan, Adib Rifqi. (2020, April 1). Syarifah Halimah Alaydrus. Thesis Commons. DOI: https://doi.org/10.31237/osf.io/xbmcs

Setiawan, Adib Rifqi. (2020, April 13). Commodification of the Sexuality in Kim Kardashian's Instagram Posts. Thesis Commons. URL: https://thesiscommons.org/mf7nw/

Setiawan, Adib Rifqi. (2020, April 13). مبادئ اللغة العربية. Thesis Commons. DOI: https://doi.org/10.31237/osf.io/2gvjf

Setiawan, Adib Rifqi. (2020, April 14). Commodification of the Sexuality in Kim Kardashian's Instagram Posts. SocArXiv. DOI: https://doi.org/10.31235/osf.io/kd6au

Setiawan, Adib Rifqi. (2020, April 14). Jalāl al-Dīn 'Abd al-Roḥmān ibn Abī Bakr al-Suyūṭ̂̄. SocArXiv. DOI: https://doi.org/10.31235/osf.io/5zf9v

Setiawan, Adib Rifqi. (2020, April 18). Musyāfahah al-Qur'ān Melalui Media Elektronik. Thesis Commons. URL: https://thesiscommons.org/ntjp9/

Setiawan, Adib Rifqi. (2020, April 2). Desain Pembelajaran untuk Membimbing Siswa Sekolah Dasar dalam Memperoleh Literasi Saintifik. EdArXiv. DOI: https://doi.org/10.35542/osf.io/u59f8

Setiawan, Adib Rifqi. (2020, April 2). JUPE My Uncut Story. Open Science Framework (OSF). DOI: https://doi.org/10.31219/osf.io/qdxga

Setiawan, Adib Rifqi. (2020, April 2). What is the Best Way to Analyze Pre-Post Data?. EdArXiv. DOI: https://doi.org/10.35542/osf.io/h4e6q

Setiawan, Adib Rifqi. (2020, April 20). Menyusun Instrumen Penilaian untuk Pembelajaran Ekologi Berorientasi Literasi Saintifik. Prosiding Seminar Nasional dan Workshop Biologi-IP A dan Pembelajaran Ke-4 (SnoWBel IV): 241-9. ISBN : 978-602-470-1703 \& e-ISBN : 978-602-470-171-0.

Setiawan, Adib Rifqi. (2020, April 21). Lembar Kegiatan Literasi Saintifik untuk Pembelajaran Jarak Jauh Topik Penyakit Coronavirus 2019 (COVID-19). Edukatif: Jurnal Ilmu Pendidikan, 02(01): 28-37. DOI: https://doi.org/10.31004/edukatif.v2i1.80

Setiawan, Adib Rifqi. (2020, April 3). Sharifah Halimah Alaydrus : a female preachers for our time. SocArXiv. DOI: https://doi.org/10.31235/osf.io/zb8qe

Setiawan, Adib Rifqi. (2020, April 4). Grace Natalie Louisa. SocArXiv. DOI: https://doi.org/10.31235/osf.io/zwf6g

Setiawan, Adib Rifqi. (2020, April 4). Grace Natalie Louisa. Thesis Commons. DOI: https://doi.org/10.31237/osf.io/u3mxv

Setiawan, Adib Rifqi. (2020, April 5). The Arrogant One. Thesis Commons. DOI: https://doi.org/10.31237/osf.io/8nmku

Setiawan, Adib Rifqi. (2020, April 9). Islamic Education in Southeast Asia. EdArXiv. DOI: https://doi.org/10.35542/osf.io/dnjqv

Setiawan, Adib Rifqi. (2020, April 9). Islamic Education in Southeast Asia. Thesis Commons. DOI: https://doi.org/10.31237/osf.io/e794d

Setiawan, Adib Rifqi. (2020, February 18). Menyusun Instrumen Penilaian untuk Pembelajaran Topik Lingkungan Berorientasi Literasi Saintifik. Prosiding Seminar Nasional Fisika (SiNaFi) 2019: 15-21. URL:

http://proceedings.upi.edu/index.php/sinafi/article/view/563

Setiawan, Adib Rifqi. (2020, January 17). Penerapan Pendekatan Saintifik dalam Pembelajaran Biologi sebagai Upaya Melatih Literasi Saintifik. Prosiding Seminar Nasional Biologi 2019 Inovasi Penelitian dan Pembelajaran Biologi III (IP2B III): 140-145. URL: 
http://semnasbiologi.conference.unesa.ac.id/ocs/index.php/semnasbio/IP2BII I/paper/viewFile/6/19

Setiawan, Adib Rifqi. (2020, January 17). Penggunaan Mabadi 'Asyroh dalam Pembelajaran Biologi untuk Meningkatkan Motivasi dan Hasil Belajar. Prosiding Seminar Nasional Biologi 2019 Inovasi Penelitian dan Pembelajaran Biologi III (IP2B III): 158164. URL:

http://semnasbiologi.conference.unesa.ac.id/ocs/index.php/semnasbio/IP2BII $\mathrm{I} /$ paper/viewFile/11/21

Setiawan, Adib Rifqi. (2020, January 17). Upaya Meningkatkan Motivasi Belajar dalam Pembelajaran Ilmu Pengetahuan Alam (IPA) Melalui Bacaan Populer. Prosiding Seminar Nasional Biologi 2019 Inovasi Penelitian dan Pembelajaran Biologi III (IP2B III): 154-157. URL: http://semnasbiologi.conference.unesa.ac.id/ocs/index.php/semnasbio/IP2BII I/paper/viewFile/5/51

Setiawan, Adib Rifqi. (2020, January 24). Pembelajaran Tematik Berorientasi Literasi Saintifik. Jurnal Basicedu: Journal of Elementary Education, 04(01): 71-80. URL: https://jbasic.org/index.php/basicedu/article/view/298

Setiawan, Adib Rifqi. (2020, March 01). Pendidikan Literasi Finansial Melalui Pembelajaran Fiqh Mu'āmalāt Berbasis Kitab Kuning. Ną̧hruna: Jurnal Pendidikan Islam, 03(01): 138-159. DOI: https://dx.doi.org/10.31538/nzh.v3i1.522

Setiawan, Adib Rifqi. (2020, May 12). Introducing the Indonesian Education System. Thesis Commons. DOI: https://doi.org/10.31237/osf.io/ygt5c

Setiawan, Adib Rifqi. (2020, May 6). Discovering the Meaning of Fadhilaturrahmi's Work. Thesis Commons. DOI: https://doi.org/10.31237/osf.io/krf7z

Setiawan, Adib Rifqi. (2020, May 6). Menyibak Makna Karya Fadhilaturrahmi. LIS Scholarship Archive. DOI: https://doi.org/10.31229/osf.io/65y4z

Setiawan, Adib Rifqi; \& Ilmiyah, Surotul. (2020, April 13). Kecerdasan Majemuk Berdasarkan Neurosains. EdArXiv. DOI: https://doi.org/10.35542/osf.io/rj2fe

Setiawan, Adib Rifqi; \& Ilmiyah, Surotul. (2020, April 13). Multiple Intelligences Based on Neuroscience. Thesis Commons. DOI: https://doi.org/10.31237/osf.io/e9fyu

Setiawan, Adib Rifqi; \& Ilmiyah, Surotul. (2020, April 7). Lembar Kegiatan Siswa untuk Pembelajaran Jarak Jauh Berdasarkan Literasi Saintifik pada Topik Penyakit Coronavirus 2019 (COVID-19). EdArXiv. DOI: https://doi.org/10.35542/osf.io/h4632

Setiawan, Adib Rifqi; Mufassaroh, Arij Zulfi. (2019, June 28). Menyusun Soal Literasi Saintifik untuk Pembelajaran Biologi Topik Plantae dan Animalia. BIOSFER: Jurnal Biologi dan Pendidikan Biologi, 04(01): 33-40. URL: http://dx.doi.org/10.23969/biosfer.v4i1.1484

Setiawan, Adib Rifqi; Puspaningrum, Mita; Umam, Khoirul. (2019, December 06). Pembelajaran Fiqh Mu'āmalāt Berorientasi Literasi Finansial. Tarbany: Indonesian Journal of Islamic Education, 06(02): 187-102. URL: https://ejournal.upi.edu/index.php/tarbawy/article/view/20887

Setiawan, Adib Rifqi; Saputri, Wahyu EKa. (2020, December 10). Pembelajaran Literasi Saintifik untuk Pendidikan Dasar. Media Penelitian Pendidikan : Jurnal Penelitian dalam Bidang Pendidikan dan Pengajaran, 14(02). DOI: https://doi.org/10.26877/mpp.v14i2.5794

Setiawan, Adib Rifqi; Saputri, Wahyu EKa. (2020, June 13). Science Motivation Questionnaire II (SMQ II) Versi Bahasa Indonesia. PsyArXiv. DOI: https://doi.org/10.31234/osf.io/tac2k

Setiawan, Adib Rifai; Utari, Setiya; Nugraha, Muhamad Gina. (2016, December 17). Mengonstruksi Rancangan Soal Domain Kompetensi Literasi Saintifik Siswa 
SMP Kelas VIII pada Topik Gerak Lurus. Seminar Nasional Fisika kee-2 (SiNaFi II), Universitas Pendidikan Indonesia (UPI). DOI: https://dx.doi.org/10.13140/RG.2.2.31856.10246/1

Setiawan, Adib Rifqi; Utari, Setiya; Nugraha, Muhamad Gina. (2017, September 22).

Mengonstruksi Rancangan Soal Domain Kompetensi Literasi Saintifik Siswa SMP Kelas VIII pada Topik Gerak Lurus. Wahana Pendidikan Fisika, 02(02): 44 48. URL: https://ejournal.upi.edu/index.php/WPF/article/view/8277/0

Siayah, Syarofis; \& Setiawan, Adib Rifqi. (2020, April 13). A Brief Explanation of Science Education. EdArXiv. DOI: https://doi.org/10.35542/osf.io/2evn3

Siayah, Syarofis; \& Setiawan, Adib Rifqi. (2020, April 13). A Brief Explanation of Science Education. Thesis Commons. DOI: https://doi.org/10.31237/osf.io/wkvsn

Velasufah, Whasfi; \& Setiawan, Adib Rifqi. (2020, April 13). Nilai Pesantren Sebagai Dasar Pendidikan Karakter. Thesis Commons. DOI: https://doi.org/10.31237/osf.io/hq6kz

Amatullah; \& Setiawan, Adib Rifqi. (2017, October 10). Nadirsyah Hosen: berkarya sebagai diaspora. Majalab SANTRI, 7: 56-59 . URL: https://issuu.com/majalahsantri/docs/santri_edisi_7/58

Feldman, DarHalevy; \& Setiawan, Adib Rifqi. (2020, April 24). Education in Israel. Thesis Commons. DOI: https://doi.org/10.31237/osf.io/62shg

Ilmiyah, Surotul; \& Setiawan, Adib Rifqi. (2020, April 7). Students' Worksheet for Distance Learning Based on Scientific Literacy in the Topic Coronavirus Disease 2019 (COVID-19). Thesis Commons. DOI: https://doi.org/10.31237/osf.io/fpg4j

Ilmiyah, Surotul; \& Setiawan, Adib Rifqi. (2020, April 7). Students' Worksheet for Distance Learning Based on Scientific Literacy in the Topic Coronavirus Disease 2019 (COVID-19). EdArXiv. DOI: https://doi.org/10.35542/osf.io/wyz5v

Setiawan, A. R. (2020, May 7). Discovering the Fundamental Problem of Four Methods to Analyze Data. Thesis Commons. DOI: https://doi.org/10.31237/osf.io/h953y

Setiawan, Adib Rifqi. (2015, November 03). Dibalik Nama Besar Albert Einstein: Dari Politik, Asmara, hingga Matematika. fisikanet.lipi.go.id. URL: http://www.fisikanet.lipi.go.id/utama.cgi?artikel\&1446556354\&2

Setiawan, Adib Rifqi. (2015, November 07). Dibalik Sampul Buku A Brief History of Time, agar pengetahuan tak hanya dinikmati ilmuwan. fisikanet.lipi.go.id. URL: http://www.fisikanet.lipi.go.id/utama.cgi?artikel\&1446855103\&2

Setiawan, Adib Rifqi. (2015, November 10). Kehidupan Asmara Hawking: raga lumpuh, jiwa masih bisa tersentuh. fisikanet.lipi.go.id. URL: http://www.fisikanet.lipi.go.id/utama.cgi?artikel\&1447145876\&2

Setiawan, Adib Rifqi. (2015, October 10). 10 Kejutan Subatomik. fisikanet.lipi.go.id. URL: http://www.fisikanet.lipi.go.id/utama.cgi?artikel\&1444577286\&3

Setiawan, Adib Rifqi. (2015, October 31). Kurir Mikroskopis Alam Semesta bukan debu biasa. fisikanet.lipi.go.id. URL: http://www.fisikanet.lipi.go.id/utama.cgi?artikel\&1446304060\&2

Setiawan, Adib Rifqi. (2017, February 24). Penerapan Pendekatan Saintifik untuk Melatibkan Literasi Saintifik dalam Domain Kompetensi pada Topik Gerak Lurus di Sekolah Menengah Pertama. Undergraduate Thesis. Bandung: Universitas Pendidikan Indonesia. URL: http://repository.upi.edu/29074/

Setiawan, Adib Rifqi. (2017, June 02). Aisha. qureta.com. URL: https://www.qureta.com/next/post/aisha-humaira

Setiawan, Adib Rifqi. (2017, June 03). Dari Yuli Hingga Julia. qureta.com. URL: https://www.qureta.com/next/post/dari-yuli-hingga-julia-2

Setiawan, Adib Rifqi. (2018, April 10). Busana: pemantas raga, pelaras jiwa. Majalab SANTRI, 8: 26-27. URL: https://issuu.com/majalahsantri/docs/majalah_santri_8/28 
Setiawan, Adib Rifqi. (2018, April 10). Eny Rochmawati Octaviani: memberikan hiburan, menyuntikkan harapan. Majalah SANTRI, 8: 15-18. URL: https://issuu.com/majalahsantri/docs/majalah_santri_8/17

Setiawan, Adib Rifqi. (2018, April 10). Rosa Amalia Iqony: paduan yakin diri dan rendah hati. Majalah SANTRI, 8: 46. URL: https://issuu.com/majalahsantri/docs/majalah_santri_8/48

Setiawan, Adib Rifqi. (2018, December 18). Irma Rahma Suwarma. qureta.com. URL: https://www.qureta.com/next/post/irma-rahma-suwarma

Setiawan, Adib Rifqi. (2018, July 03). Tangis Daniela Hantuchová. qureta.com. URL: https://www.qureta.com/next/post/tangis-daniela-hantuchova

Setiawan, Adib Rifqi. (2018, July 16). Rustriningsih, Srikandi Tersisih. qureta.com. URL: https://www.qureta.com/next/post/rustriningsih-srikandi-tersisih

Setiawan, Adib Rifqi. (2018, June 27). Ice. qureta.com. URL: https://www.qureta.com/next/post/ice

Setiawan, Adib Rifqi. (2018, June 28). Dewi Perssik. qureta.com. URL: https://www.qureta.com/next/post/dewi-perssik

Setiawan, Adib Rifqi. (2018, March 06). Breast Capital. qureta.com. URL: https://www.qureta.com/next/post/breast-capital

Setiawan, Adib Rifqi. (2018, March 06). Menyoal Vokal Duo Serigala. qureta.com. URL: https://www.qureta.com/next/post/menyoal-vokal-duo-serigala

Setiawan, Adib Rifqi. (2018, March 07). Mengenal Oza Kioza. qureta.com. URL: https://www.qureta.com/next/post/mengenal-oza-kioza

Setiawan, Adib Rifqi. (2018, March 09). Asal Usul Nama Via Vallen. qureta.com. URL: https://www.qureta.com/next/post/asal-usul-nama-via-vallen

Setiawan, Adib Rifqi. (2018, March 09). Kepedulian Airin Rachmi Diany pada Pendidikan. qureta.com. URL: https://www.qureta.com/next/post/kepedulian-airin-rachmidiany-pada-pendidikan

Setiawan, Adib Rifqi. (2018, March 09). Ketika YoonA Menyaksikan Real Madrid Menghempaskan PSG. qureta.com. URL: https://www.qureta.com/next/post/ketika-yoona-menyaksikan-real-madridmenghempaskan-psg

Setiawan, Adib Rifqi. (2018, March 09). Laila Fariha Zein (a.k.a. Uus atau Febi). qureta.com. URL: https://www.qureta.com/next/post/laila-fariha-zein-febi

Setiawan, Adib Rifqi. (2018, March 09). Pantat Perekat Umat. qureta.com. URL: https://www.qureta.com/next/post/pantat-perekat-umat

Setiawan, Adib Rifqi. (2018, March 09). Sisi Religi Grace Natalie. qureta.com. URL: https://www.qureta.com/next/post/sisi-religi-grace-natalie

Setiawan, Adib Rifqi. (2018, March 10). Venice Min. qureta.com. URL: https://www.qureta.com/next/post/venice-min

Setiawan, Adib Rifqi. (2018, March 11). Kisah Kasih Ayah di Balik Mata Najwa. qureta.com. URL: https://www.qureta.com/next/post/kisah-kasih-ayah-di-balik-mata-najwa

Setiawan, Adib Rifqi. (2018, March 11). Rosa Amalia Iqony. qureta.com. URL: https://www.qureta.com/next/post/rosa-amalia-iqony

Setiawan, Adib Rifqi. (2018, March 12). Clara Ng. qureta.com. URL: https://www.qureta.com/next/post/clara-ng

Setiawan, Adib Rifqi. (2018, March 14). Meniti Ilmuwati. qureta.com. URL: https://www.qureta.com/next/post/meniti-ilmuwati

Setiawan, Adib Rifqi. (2018, March 14). Surely You're Joking, Mrs. Ilmy!. qureta.com. URL: https://www.qureta.com/next/post/surely-you-re-joking-mrs-ilmy

Setiawan, Adib Rifqi. (2018, March 15). Eny R. Octaviani. qureta.com. URL: https://www.qureta.com/next/post/eny-r-octaviani 
Setiawan, Adib Rifqi. (2018, March 17). Maryam Musfiroh: An Educator for Our Time. qureta.com. URL: https://www.qureta.com/next/post/maryam-musfiroh-aneducator-for-our-time

Setiawan, Adib Rifqi. (2018, March 19). Airin Rachmi Diany, Lilin Penerang Masyarakat Urban. qureta.com. URL: https://www.qureta.com/next/post/airin-rachmi-diany-lilinpenerang-masyarakat-urban

Setiawan, Adib Rifqi. (2018, March 19). Guru yang Menyapih: Catatan Perjalanan Pribadi Nong Darol Mahmada. qureta.com. URL: https://www.qureta.com/next/post/guruyang-menyapih-catatan-perjalanan-pribadi-nong-darol-mahmada

Setiawan, Adib Rifqi. (2018, March 19). Kamu dalam Aku: A Brief Story of Park Bom. qureta.com. URL: https://www.qureta.com/next/post/kamu-dalam-aku-a-brief-storyof-park-bom

Setiawan, Adib Rifqi. (2018, March 21). Bidadari di Kesunyian itu Bernama Maria Sharapova. qureta.com. URL: https://www.qureta.com/next/post/bidadari-di-kesunyianitu-bernama-maria-sharapova

Setiawan, Adib Rifqi. (2018, March 25). Novi Kaka: Sahabat, Panutan, Pembimbing. qureta.com. URL: https://www.qureta.com/next/post/novi-kaka-sahabat-panutanpembimbing

Setiawan, Adib Rifqi. (2018, May 24). Fakhrun. qureta.com. URL: https://www.qureta.com/next/post/fakhrun

Setiawan, Adib Rifqi. (2018, November 24). Penerapan Pendekatan Saintifik untuk Melatih Literasi Saintifik dalam Domain Kompetensi pada Topik Gerak Lurus di Sekolah Menengah Pertama. Seminar Nasional Fisika ke-4 (SiNaFi IV), Universitas Pendidikan Indonesia (UPI). DOI: https://dx.doi.org/10.13140/RG.2.2.23154.04809

Setiawan, Adib Rifqi. (2018, October 05). Karen Armstrong. qureta.com. URL: https://www.qureta.com/next/post/karen-armstrong

Setiawan, Adib Rifqi. (2018, September 17). Lola Zieta Azelien. qureta.com. URL: https://www.qureta.com/next/post/lola-zieta-azelien

Setiawan, Adib Rifqi. (2019, August 21). Penyusunan Program Pembelajaran Biologi Berorientasi Literasi Saintifik. Seminar Nasional Sains \& Entrepreneurship VI (SNSE VI), Universitas PGRI Semarang (UPGRIS). DOI: https://dx.doi.org/10.13140/RG.2.2.13716.86400

Setiawan, Adib Rifqi. (2019, December 20). Literasi Saintifik Berdasarkan Kecerdasan Majemuk dan Motivasi Belajar. Media Penelitian Pendidikan: Jurnal Penelitian dalam Bidang Pendidikan dan Pengajaran, 13(02): 126-137. DOI: http://dx.doi.org/10.26877/mpp.v13i2.4913

Setiawan, Adib Rifqi. (2019, December 23). Contoh Langkah Pembelajaran Berorientasi Literasi Saintifik. santrimilenial.net. URL: https://santrimilenial.net/contoh-langkahpembelajaran-berorientasi-literasi-saintifik/

Setiawan, Adib Rifqi. (2019, December 30). Instrumen Penilaian Pembelajaran Fiqh Mu'āmalāt Berorientasi Literasi Finansial. Eklektik: Jurnal Pendidikan Ekonomi dan Kewirausahaan, 02(02): 258-272. DOI: http://dx.doi.org/10.24014/ekl.v2i2.8117

Setiawan, Adib Rifqi. (2019, June 14). Deasy Noviyanti, Perempuan Berbadan Defisit Lemak. qureta.com. URL: https://www.qureta.com/next/post/deasy-noviyantiperempuan-berbadan-defisit-lemak

Setiawan, Adib Rifqi. (2019, June 26). Peningkatan Literasi Saintifik melalui Pembelajaran Biologi Menggunakan Pendekatan Saintifik. Journal of Biology Education, 02(01): 223-235.

URL: http://journal.stainkudus.ac.id/index.php/jbe/article/view/5278

Setiawan, Adib Rifqi. (2019, March 23). Penerapan Pendekatan Saintifik dalam Pembelajaran Biologi sebagai Upaya Melatih Literasi Saintifik Siswa Sekolah Menengah. 
Seminar Nasional Biologi 2019 Inovasi Penelitian dan Pembelajaran Biologi III (IP2B III), Universitas Negeri Surabaya (UNESA). DOI:

https:/ /dx.doi.org/10.13140/RG.2.2.19798.60484

Setiawan, Adib Rifqi. (2019, March 23). Penggunaan Naḍom Mabādī'Asyroh dalam

Pembelajaran Biologi untuk Meningkatkan Motivasi dan Hasil Belajar. Seminar

Nasional Biologi 2019 Inovasi Penelitian dan Pembelajaran Biologi III (IP2B III),

Universitas Negeri Surabaya (UNESA). DOI:

https://dx.doi.org/10.13140/RG.2.2.33220.37763

Setiawan, Adib Rifqi. (2019, March 23). Upaya Meningkatkan Motivasi Belajar dalam

Pembelajaran Ilmu Pengetahuan Alam (IPA) Melalui Bacaan Populer. Seminar

Nasional Biologi 2019 Inovasi Penelitian dan Pembelajaran Biologi III (IP2B III),

Universitas Negeri Surabaya (UNESA). DOI:

https://dx.doi.org/10.13140/RG.2.2.13087.71847

Setiawan, Adib Rifqi. (2019, May 07). Penerapan Pendekatan Saintifik untuk Melatih Literasi

Saintifik dalam Domain Kompetensi pada Topik Gerak Lurus di Sekolah

Menengah Pertama. Prosiding Seminar Nasional Fisika (SiNaFi) 2018: 7-13. URL:

http:// proceedings.upi.edu/index.php/sinafi/article/view/355

Setiawan, Adib Rifqi. (2019, November 23). Analisis Keabsahan dan Keandalan Science

Motivation Questionnaire II (SMQ II) Versi Bahasa Indonesia. Seminar Nasional

Fisika V (SiNaFi 5.0), Universitas Pendidikan Indonesia (UPI). DOI:

https://doi.org/10.31237/osf.io/6zeph

Setiawan, Adib Rifqi. (2019, November 23). Menyusun Instrumen Penilaian untuk Pembelajaran

Topik Lingkungan Berorientasi Literasi Saintifik. Seminar Nasional Fisika $V$

(SiNaFi 5.0), Universitas Pendidikan Indonesia (UPI). DOI:

https://dx.doi.org/10.35542/osf.io/sc6d2

Setiawan, Adib Rifqi. (2019, November 23). Profil Literasi Saintifik Berdasarkan Kecerdasan

Majemuk dan Motivasi Belajar. Seminar Nasional Fisika V (SiNaFi 5.0),

Universitas Pendidikan Indonesia (UPI). DOI:

https://dx.doi.org/10.35542/osf.io/m7n95

Setiawan, Adib Rifqi. (2019, October 02). Efektivitas Pembelajaran Biologi Berorientasi Literasi Saintifik. Thabiea : Journal of Natural Science Teaching, 02 (02): 83-94. DOI: http://dx.doi.org/10.21043/thabiea.v2i2.5345

Setiawan, Adib Rifqi. (2019, October 05). Menyusun Instrumen Penilaian untuk Pembelajaran Ekologi Berorientasi Literasi Saintifik. Seminar Nasional \& Workshop Biologi, IPA, dan Pembelajarannya ke-4 (SnoWBel IV), Universitas Negeri Malang (UM). DOI: https://dx.doi.org/10.13140/RG.2.2.21931.39206

Setiawan, Adib Rifqi. (2019, October 14). Penyusunan Program Pembelajaran Biologi Berorientasi Literasi Saintifik. Seminar Nasional Sains \& Entrepreneurship VI (SNSE VI): 255-1-8. URL:

http://conference.upgris.ac.id/index.php/snse/article/view/255

Setiawan, Adib Rifqi. (2019, October 8). Biografi Clara Ng Perempuan Penulis Asal Indonesia. Psy/ArXiv. DOI: https://doi.org/10.31234/osf.io/yk8sx

Setiawan, Adib Rifqi. (2019, September 30). Instrumen Penilaian untuk Pembelajaran Ekologi Berorientasi Literasi Saintifik. Assimilation: Indonesian Journal of Biology Education, 02(02): 42-46. DOI: https://dx.doi.org/10.17509/aijbe.v2i2.19250

Setiawan, Adib Rifqi. (2020, April 1). Sharifah Halimah Alaydrus. Thesis Commons. DOI: https://doi.org/10.31237/osf.io/fp79c

Setiawan, Adib Rifqi. (2020, April 1). Syarifah Halimah Alaydrus. Thesis Commons. DOI: https://doi.org/10.31237/osf.io/xbmcs

Setiawan, Adib Rifqi. (2020, April 13). Commodification of the Sexuality in Kim Kardashian's Instagram Posts. Thesis Commons. URL: https://thesiscommons.org/mf7nw/ 
Setiawan, Adib Rifqi. (2020, April 13). مبادئ اللغة العربية. Thesis Commons. DOI: https://doi.org/10.31237/osf.io/2gvjf

Setiawan, Adib Rifqi. (2020, April 14). Commodification of the Sexuality in Kim Kardashian's Instagram Posts. SocArXiv. DOI: https://doi.org/10.31235/osf.io/kd6au

Setiawan, Adib Rifqi. (2020, April 14). Jalāl al-Dīn 'Abd al-Roḥmān ibn Abī Bakr al-Suyūṭi. SocArXiv. DOI: https://doi.org/10.31235/osf.io/5zf9v

Setiawan, Adib Rifqi. (2020, April 18). Musyāfahah al-Qur'ān Melalui Media Elektronik. Thesis Commons. URL: https://thesiscommons.org/ntjp9/

Setiawan, Adib Rifqi. (2020, April 2). Desain Pembelajaran untuk Membimbing Siswa Sekolah Dasar dalam Memperoleh Literasi Saintifik. EdArXiv. DOI: https://doi.org/10.35542/osf.io/u59f8

Setiawan, Adib Rifqi. (2020, April 2). JUPE My Uncut Story. Open Science Framework (OSF). DOI: https://doi.org/10.31219/osf.io/qdxga

Setiawan, Adib Rifqi. (2020, April 2). What is the Best Way to Analyze Pre-Post Data?. EdArXiv. DOI: https://doi.org/10.35542/osf.io/h4e6q

Setiawan, Adib Rifqi. (2020, April 20). Menyusun Instrumen Penilaian untuk Pembelajaran Ekologi Berorientasi Literasi Saintifik. Prosiding Seminar Nasional dan Workshop Biologi-IP A dan Pembelajaran Ke-4 (SnoWBel IV): 241-9. ISBN : 978-602-470-1703 \& e-ISBN : 978-602-470-171-0.

Setiawan, Adib Rifqi. (2020, April 21). Lembar Kegiatan Literasi Saintifik untuk Pembelajaran Jarak Jauh Topik Penyakit Coronavirus 2019 (COVID-19). Edukatif: Jumal Ilmu Pendidikan, 02(01): 28-37. DOI: https://doi.org/10.31004/edukatif.v2i1.80

Setiawan, Adib Rifqi. (2020, April 3). Sharifah Halimah Alaydrus : a female preachers for our time. SocArXiv. DOI: https://doi.org/10.31235/osf.io/zb8qe

Setiawan, Adib Rifqi. (2020, April 4). Grace Natalie Louisa. SocArXiv. DOI: https://doi.org/10.31235/osf.io/zwf6g

Setiawan, Adib Rifqi. (2020, April 4). Grace Natalie Louisa. Thesis Commons. DOI: https://doi.org/10.31237/osf.io/u3mxv

Setiawan, Adib Rifqi. (2020, April 5). The Arrogant One. Thesis Commons. DOI: https://doi.org/10.31237/osf.io/8nmku

Setiawan, Adib Rifqi. (2020, April 9). Islamic Education in Southeast Asia. EdArXiv. DOI: https://doi.org/10.35542/osf.io/dnjqv

Setiawan, Adib Rifqi. (2020, April 9). Islamic Education in Southeast Asia. Thesis Commons. DOI: https://doi.org/10.31237/osf.io/e794d

Setiawan, Adib Rifqi. (2020, February 18). Menyusun Instrumen Penilaian untuk Pembelajaran Topik Lingkungan Berorientasi Literasi Saintifik. Prosiding Seminar Nasional Fisika (SiNaFi) 2019: 15-21. URL:

http://proceedings.upi.edu/index.php/sinafi/article/view/563

Setiawan, Adib Rifqi. (2020, January 17). Penerapan Pendekatan Saintifik dalam Pembelajaran Biologi sebagai Upaya Melatih Literasi Saintifik. Prosiding Seminar Nasional Biologi 2019 Inovasi Penelitian dan Pembelajaran Biologi III (IP2B III): 140-145. URL: http://semnasbiologi.conference.unesa.ac.id/ocs/index.php/semnasbio/IP2BII I/paper/viewFile/6/19

Setiawan, Adib Rifqi. (2020, January 17). Penggunaan Mabadi 'Asyroh dalam Pembelajaran Biologi untuk Meningkatkan Motivasi dan Hasil Belajar. Prosiding Seminar Nasional Biologi 2019 Inovasi Penelitian dan Pembelajaran Biologi III (IP2B III): 158164. URL:

http://semnasbiologi.conference.unesa.ac.id/ocs/index.php/semnasbio/IP2BII I/paper/viewFile/11/21

Setiawan, Adib Rifqi. (2020, January 17). Upaya Meningkatkan Motivasi Belajar dalam Pembelajaran Ilmu Pengetahuan Alam (IPA) Melalui Bacaan Populer. Prosiding 
Seminar Nasional Biologi 2019 Inovasi Penelitian dan Pembelajaran Biologi III (IP2B III): 154-157. URL:

http://semnasbiologi.conference.unesa.ac.id/ocs/index.php/semnasbio/IP2BII I/paper/viewFile/5/51

Setiawan, Adib Rifqi. (2020, January 24). Pembelajaran Tematik Berorientasi Literasi Saintifik. Jurnal Basicedu: Journal of Elementary Education, 04(01): 71-80. URL: https://jbasic.org/index.php/basicedu/article/view/298

Setiawan, Adib Rifqi. (2020, March 01). Pendidikan Literasi Finansial Melalui Pembelajaran Fiqh Mu'āmalāt Berbasis Kitab Kuning. Ną̧hruna: Jurnal Pendidikan Islam, 03(01): 138-159. DOI: https://dx.doi.org/10.31538/nzh.v3i1.522

Setiawan, Adib Rifqi. (2020, May 12). Introducing the Indonesian Education System. Thesis Commons. DOI: https://doi.org/10.31237/osf.io/ygt5c

Setiawan, Adib Rifqi. (2020, May 6). Discovering the Meaning of Fadhilaturrahmi's Work. Thesis Commons. DOI: https://doi.org/10.31237/osf.io/krf7z

Setiawan, Adib Rifqi. (2020, May 6). Menyibak Makna Karya Fadhilaturrahmi. LIS Scholarship Archive. DOI: https://doi.org/10.31229/osf.io/65y4z

Setiawan, Adib Rifqi; \& Ilmiyah, Surotul. (2020, April 13). Kecerdasan Majemuk Berdasarkan Neurosains. EdArXiv. DOI: https://doi.org/10.35542/osf.io/rj2fe

Setiawan, Adib Rifqi; \& Ilmiyah, Surotul. (2020, April 13). Multiple Intelligences Based on Neuroscience. Thesis Commons. DOI: https://doi.org/10.31237/osf.io/e9fyu

Setiawan, Adib Rifqi; \& Ilmiyah, Surotul. (2020, April 7). Lembar Kegiatan Siswa untuk Pembelajaran Jarak Jauh Berdasarkan Literasi Saintifik pada Topik Penyakit Coronavirus 2019 (COVID-19). EdArXiv. DOI: https://doi.org/10.35542/osf.io/h4632

Setiawan, Adib Rifqi; Mufassaroh, Arij Zulfi. (2019, June 28). Menyusun Soal Literasi Saintifik untuk Pembelajaran Biologi Topik Plantae dan Animalia. BIOSFER: Jurnal Biologi dan Pendidikan Biologi, 04(01): 33-40. URL: http://dx.doi.org/10.23969/biosfer.v4i1.1484

Setiawan, Adib Rifqi; Puspaningrum, Mita; Umam, Khoirul. (2019, December 06). Pembelajaran Fiqh Mu'āmalāt Berorientasi Literasi Finansial. Tarbany: Indonesian Journal of Islamic Education, 06(02): 187-102. URL: https:// ejournal.upi.edu/index.php/tarbawy/article/view/20887

Setiawan, Adib Rifqi; Saputri, Wahyu EKa. (2020, December 10). Pembelajaran Literasi Saintifik untuk Pendidikan Dasar. Media Penelitian Pendidikan : Jurnal Penelitian dalam Bidang Pendidikan dan Pengajaran, 14(02). DOI: https://doi.org/10.26877/mpp.v14i2.5794

Setiawan, Adib Rifai; Saputri, Wahyu EKa. (2020, June 13). Science Motivation Questionnaire II (SMQ II) Versi Bahasa Indonesia. Psy ArXiv. DOI: https://doi.org/10.31234/osf.io/tac2k

Setiawan, Adib Rifqi; Utari, Setiya; Nugraha, Muhamad Gina. (2016, December 17). Mengonstruksi Rancangan Soal Domain Kompetensi Literasi Saintifik Siswa SMP Kelas VIII pada Topik Gerak Lurus. Seminar Nasional Fisika ke-2 (SiNaFi II), Universitas Pendidikan Indonesia (UPI). DOI: https://dx.doi.org/10.13140/RG.2.2.31856.10246/1

Setiawan, Adib Rifqi; Utari, Setiya; Nugraha, Muhamad Gina. (2017, September 22). Mengonstruksi Rancangan Soal Domain Kompetensi Literasi Saintifik Siswa SMP Kelas VIII pada Topik Gerak Lurus. Wahana Pendidikan Fisika, 02(02): 44 48. URL: https:// ejournal.upi.edu/index.php/WPF/article/view/8277/0

Siayah, Syarofis; \& Setiawan, Adib Rifqi. (2020, April 13). A Brief Explanation of Science Education. EdArXiv. DOI: https://doi.org/10.35542/osf.io/2evn3 
Siayah, Syarofis; \& Setiawan, Adib Rifqi. (2020, April 13). A Brief Explanation of Science Education. Thesis Commons. DOI: https://doi.org/10.31237/osf.io/wkvsn

Velasufah, Whasfi; \& Setiawan, Adib Rifqi. (2020, April 13). Nilai Pesantren Sebagai Dasar Pendidikan Karakter. Thesis Commons. DOI: https://doi.org/10.31237/osf.io/hq6kz

Amatullah; \& Setiawan, Adib Rifqi. (2017, October 10). Nadirsyah Hosen: berkarya sebagai diaspora. Majalab SANTRI, 7: 56-59. URL: https://issuu.com/majalahsantri/docs/santri_edisi_7/58

Feldman, DarHalevy; \& Setiawan, Adib Rifqi. (2020, April 24). Education in Israel. Thesis Commons. DOI: https://doi.org/10.31237/osf.io/62shg

Ilmiyah, Surotul; \& Setiawan, Adib Rifqi. (2020, April 7). Students' Worksheet for Distance Learning Based on Scientific Literacy in the Topic Coronavirus Disease 2019 (COVID-19). Thesis Commons. DOI: https://doi.org/10.31237/osf.io/fpg4j

Ilmiyah, Surotul; \& Setiawan, Adib Rifqi. (2020, April 7). Students' Worksheet for Distance Learning Based on Scientific Literacy in the Topic Coronavirus Disease 2019 (COVID-19). EdArXiv. DOI: https://doi.org/10.35542/osf.io/wyz5v

Setiawan, A. R. (2020, May 7). Discovering the Fundamental Problem of Four Methods to Analyze Data. Thesis Commons. DOI: https://doi.org/10.31237/osf.io/h953y

Setiawan, Adib Rifqi. (2015, November 03). Dibalik Nama Besar Albert Einstein: Dari Politik, Asmara, hingga Matematika. fisikanet.lipi.go.id. URL:

http://www.fisikanet.lipi.go.id/utama.cgi?artikel\&1446556354\&2

Setiawan, Adib Rifqi. (2015, November 07). Dibalik Sampul Buku A Brief History of Time, agar pengetahuan tak hanya dinikmati ilmuwan. fisikanet.lipi.go.id. URL: http://www.fisikanet.lipi.go.id/utama.cgi?artikel\&1446855103\&2

Setiawan, Adib Rifqi. (2015, November 10). Kehidupan Asmara Hawking: raga lumpuh, jiwa masih bisa tersentuh. fisikanet.lipi.go.id. URL: http://www.fisikanet.lipi.go.id/utama.cgi?artikel\&1447145876\&2

Setiawan, Adib Rifqi. (2015, October 10). 10 Kejutan Subatomik. fisikanet.lipi.go.id. URL: http:/ /www.fisikanet.lipi.go.id/utama.cgi?artikel\&1444577286\&3

Setiawan, Adib Rifqi. (2015, October 31). Kurir Mikroskopis Alam Semesta bukan debu biasa. fisikeanet.lipi.go.id. URL: http://www.fisikanet.lipi.go.id/utama.cgi?artikel\&1446304060\&2

Setiawan, Adib Rifqi. (2017, February 24). Penerapan Pendekatan Saintifik untuk. Melatibkan Literasi Saintifik dalam Domain Kompetensi pada Topik Gerak Lurus di Sekolah Menengah Pertama. Undergraduate Thesis. Bandung: Universitas Pendidikan Indonesia. URL: http://repository.upi.edu/29074/

Setiawan, Adib Rifqi. (2017, June 02). Aisha. qureta.com. URL: https://www.qureta.com/next/post/aisha-humaira

Setiawan, Adib Rifqi. (2017, June 03). Dari Yuli Hingga Julia. qureta.com. URL: https://www.qureta.com/next/post/dari-yuli-hingga-julia-2

Setiawan, Adib Rifqi. (2018, April 10). Busana: pemantas raga, pelaras jiwa. Majalab SANTRI, 8: 26-27. URL: https://issuu.com/majalahsantri/docs/majalah_santri_8/28

Setiawan, Adib Rifqi. (2018, April 10). Eny Rochmawati Octaviani: memberikan hiburan, menyuntikkan harapan. Majalah SANTRI, 8: 15-18. URL: https://issuu.com/majalahsantri/docs/majalah_santri_8/17

Setiawan, Adib Rifqi. (2018, April 10). Rosa Amalia Iqony: paduan yakin diri dan rendah hati. Majalah SANTRI, 8: 46. URL: https://issuu.com/majalahsantri/docs/majalah_santri_8/48

Setiawan, Adib Rifqi. (2018, December 18). Irma Rahma Suwarma. qureta.com. URL: https://www.qureta.com/next/post/irma-rahma-suwarma 
Setiawan, Adib Rifqi. (2018, July 03). Tangis Daniela Hantuchová. qureta.com. URL: https://www.qureta.com/next/post/tangis-daniela-hantuchova

Setiawan, Adib Rifqi. (2018, July 16). Rustriningsih, Srikandi Tersisih. qureta.com. URL: https://www.qureta.com/next/post/rustriningsih-srikandi-tersisih

Setiawan, Adib Rifqi. (2018, June 27). Ice. qureta.com. URL: https://www.qureta.com/next/post/ice

Setiawan, Adib Rifqi. (2018, June 28). Dewi Perssik. qureta.com. URL: https://www.qureta.com/next/post/dewi-perssik

Setiawan, Adib Rifqi. (2018, March 06). Breast Capital. qureta.com. URL: https://www.qureta.com/next/post/breast-capital

Setiawan, Adib Rifqi. (2018, March 06). Menyoal Vokal Duo Serigala. qureta.com. URL: https://www.qureta.com/next/post/menyoal-vokal-duo-serigala

Setiawan, Adib Rifqi. (2018, March 07). Mengenal Oza Kioza. qureta.com. URL: https://www.qureta.com/next/post/mengenal-oza-kioza

Setiawan, Adib Rifqi. (2018, March 09). Asal Usul Nama Via Vallen. qureta.com. URL: https://www.qureta.com/next/post/asal-usul-nama-via-vallen

Setiawan, Adib Rifqi. (2018, March 09). Kepedulian Airin Rachmi Diany pada Pendidikan. qureta.com. URL: https://www.qureta.com/next/post/kepedulian-airin-rachmidiany-pada-pendidikan

Setiawan, Adib Rifqi. (2018, March 09). Ketika YoonA Menyaksikan Real Madrid Menghempaskan PSG. qureta.com. URL:

https://www.qureta.com/next/post/ketika-yoona-menyaksikan-real-madridmenghempaskan-psg

Setiawan, Adib Rifqi. (2018, March 09). Laila Fariha Zein (a.k.a. Uus atau Febi). qureta.com. URL: https://www.qureta.com/next/post/laila-fariha-zein-febi

Setiawan, Adib Rifqi. (2018, March 09). Pantat Perekat Umat. qureta.com. URL: https://www.qureta.com/next/post/pantat-perekat-umat

Setiawan, Adib Rifqi. (2018, March 09). Sisi Religi Grace Natalie. qureta.com. URL: https://www.qureta.com/next/post/sisi-religi-grace-natalie

Setiawan, Adib Rifqi. (2018, March 10). Venice Min. qureta.com. URL: https://www.qureta.com/next/post/venice-min

Setiawan, Adib Rifqi. (2018, March 11). Kisah Kasih Ayah di Balik Mata Najwa. qureta.com. URL: https://www.qureta.com/next/post/kisah-kasih-ayah-di-balik-mata-najwa

Setiawan, Adib Rifqi. (2018, March 11). Rosa Amalia Iqony. qureta.com. URL: https://www.qureta.com/next/post/rosa-amalia-iqony

Setiawan, Adib Rifqi. (2018, March 12). Clara Ng. qureta.com. URL: https://www.qureta.com/next/post/clara-ng

Setiawan, Adib Rifqi. (2018, March 14). Meniti Ilmuwati. qureta.com. URL: https://www.qureta.com/next/post/meniti-ilmuwati

Setiawan, Adib Rifqi. (2018, March 14). Surely You're Joking, Mrs. Ilmy!. qureta.com. URL: https://www.qureta.com/next/post/surely-you-re-joking-mrs-ilmy

Setiawan, Adib Rifqi. (2018, March 15). Eny R. Octaviani. qureta.com. URL: https://www.qureta.com/next/post/eny-r-octaviani

Setiawan, Adib Rifqi. (2018, March 17). Maryam Musfiroh: An Educator for Our Time. qureta.com. URL: https://www.qureta.com/next/post/maryam-musfiroh-aneducator-for-our-time

Setiawan, Adib Rifqi. (2018, March 19). Airin Rachmi Diany, Lilin Penerang Masyarakat Urban. qureta.com. URL: https://www.qureta.com/next/post/airin-rachmi-diany-lilinpenerang-masyarakat-urban 
Setiawan, Adib Rifqi. (2018, March 19). Guru yang Menyapih: Catatan Perjalanan Pribadi Nong Darol Mahmada. qureta.com. URL: https://www.qureta.com/next/post/guruyang-menyapih-catatan-perjalanan-pribadi-nong-darol-mahmada

Setiawan, Adib Rifqi. (2018, March 19). Kamu dalam Aku: A Brief Story of Park Bom. qureta.com. URL: https://www.qureta.com/next/post/kamu-dalam-aku-a-brief-storyof-park-bom

Setiawan, Adib Rifqi. (2018, March 21). Bidadari di Kesunyian itu Bernama Maria Sharapova. qureta.com. URL: https://www.qureta.com/next/post/bidadari-di-kesunyianitu-bernama-maria-sharapova

Setiawan, Adib Rifqi. (2018, March 25). Novi Kaka: Sahabat, Panutan, Pembimbing. qureta.com. URL: https://www.qureta.com/next/post/novi-kaka-sahabat-panutanpembimbing

Setiawan, Adib Rifqi. (2018, May 24). Fakhrun. qureta.com. URL: https://www.qureta.com/next/post/fakhrun

Setiawan, Adib Rifqi. (2018, November 24). Penerapan Pendekatan Saintifik untuk Melatih Literasi Saintifik dalam Domain Kompetensi pada Topik Gerak Lurus di Sekolah Menengah Pertama. Seminar Nasional Fisika ke-4 (SiNaFi IV), Universitas Pendidikan Indonesia (UPI). DOI: https://dx.doi.org/10.13140/RG.2.2.23154.04809

Setiawan, Adib Rifqi. (2018, October 05). Karen Armstrong. qureta.com. URL: https://www.qureta.com/next/post/karen-armstrong

Setiawan, Adib Rifqi. (2018, September 17). Lola Zieta Azelien. qureta.com. URL: https://www.qureta.com/next/post/lola-zieta-azelien

Setiawan, Adib Rifqi. (2019, August 21). Penyusunan Program Pembelajaran Biologi Berorientasi Literasi Saintifik. Seminar Nasional Sains \& Entrepreneurship VI (SNSE VI), Universitas PGRI Semarang (UPGRIS). DOI: https://dx.doi.org/10.13140/RG.2.2.13716.86400

Setiawan, Adib Rifqi. (2019, December 20). Literasi Saintifik Berdasarkan Kecerdasan Majemuk dan Motivasi Belajar. Media Penelitian Pendidikan: Jurnal Penelitian dalam Bidang Pendidikan dan Pengajaran, 13(02): 126-137. DOI: http://dx.doi.org/10.26877/mpp.v13i2.4913

Setiawan, Adib Rifqi. (2019, December 23). Contoh Langkah Pembelajaran Berorientasi Literasi Saintifik. santrimilenial.net. URL: https://santrimilenial.net/contoh-langkahpembelajaran-berorientasi-literasi-saintifik/

Setiawan, Adib Rifqi. (2019, December 30). Instrumen Penilaian Pembelajaran Fiqh Mu'āmalāt Berorientasi Literasi Finansial. Eklektik: Jurnal Pendidikan Ekonomi dan Kewirausahaan, 02(02): 258-272. DOI: http://dx.doi.org/10.24014/ekl.v2i2.8117

Setiawan, Adib Rifqi. (2019, June 14). Deasy Noviyanti, Perempuan Berbadan Defisit Lemak. qureta.com. URL: https://www.qureta.com/next/post/deasy-noviyantiperempuan-berbadan-defisit-lemak

Setiawan, Adib Rifqi. (2019, June 26). Peningkatan Literasi Saintifik melalui Pembelajaran Biologi Menggunakan Pendekatan Saintifik. Journal of Biology Education, 02(01): 223-235. URL: http://journal.stainkudus.ac.id/index.php/jbe/article/view/5278

Setiawan, Adib Rifqi. (2019, March 23). Penerapan Pendekatan Saintifik dalam Pembelajaran Biologi sebagai Upaya Melatih Literasi Saintifik Siswa Sekolah Menengah. Seminar Nasional Biologi 2019 Inovasi Penelitian dan Pembelajaran Biologi III (IP2B III), Universitas Negeri Surabaya (UNESA). DOI: https://dx.doi.org/10.13140/RG.2.2.19798.60484

Setiawan, Adib Rifqi. (2019, March 23). Penggunaan Naḍom Mabādí'Asyroh dalam Pembelajaran Biologi untuk Meningkatkan Motivasi dan Hasil Belajar. Seminar Nasional Biologi 2019 Inovasi Penelitian dan Pembelajaran Biologi III (IP2B III), 
Universitas Negeri Surabaya (UNESA). DOI:

https://dx.doi.org/10.13140/RG.2.2.33220.37763

Setiawan, Adib Rifqi. (2019, March 23). Upaya Meningkatkan Motivasi Belajar dalam

Pembelajaran Ilmu Pengetahuan Alam (IPA) Melalui Bacaan Populer. Seminar

Nasional Biologi 2019 Inovasi Penelitian dan Pembelajaran Biologi III (IP2B III),

Universitas Negeri Surabaya (UNESA). DOI:

https://dx.doi.org/10.13140/RG.2.2.13087.71847

Setiawan, Adib Rifqi. (2019, May 07). Penerapan Pendekatan Saintifik untuk Melatih Literasi

Saintifik dalam Domain Kompetensi pada Topik Gerak Lurus di Sekolah

Menengah Pertama. Prosiding Seminar Nasional Fisika (SiNaFi) 2018: 7-13. URL:

http://proceedings.upi.edu/index.php/sinafi/article/view/355

Setiawan, Adib Rifqi. (2019, November 23). Analisis Keabsahan dan Keandalan Science

Motivation Questionnaire II (SMQ II) Versi Bahasa Indonesia. Seminar Nasional

Fisika V (SiNaFi 5.0), Universitas Pendidikan Indonesia (UPI). DOI:

https://doi.org/10.31237/osf.io/6zeph

Setiawan, Adib Rifqi. (2019, November 23). Menyusun Instrumen Penilaian untuk Pembelajaran

Topik Lingkungan Berorientasi Literasi Saintifik. Seminar Nasional Fisika $V$

(SiNaFi 5.0), Universitas Pendidikan Indonesia (UPI). DOI:

https://dx.doi.org/10.35542/osf.io/sc6d2

Setiawan, Adib Rifqi. (2019, November 23). Profil Literasi Saintifik Berdasarkan Kecerdasan

Majemuk dan Motivasi Belajar. Seminar Nasional Fisika V (SiNaFi 5.0),

Universitas Pendidikan Indonesia (UPI). DOI:

https://dx.doi.org/10.35542/osf.io/m7n95

Setiawan, Adib Rifqi. (2019, October 02). Efektivitas Pembelajaran Biologi Berorientasi Literasi Saintifik. Thabiea : Journal of Natural Science Teaching, 02 (02): 83-94. DOI: http://dx.doi.org/10.21043/thabiea.v2i2.5345

Setiawan, Adib Rifqi. (2019, October 05). Menyusun Instrumen Penilaian untuk Pembelajaran Ekologi Berorientasi Literasi Saintifik. Seminar Nasional \& Workshop Biologi, IPA, dan Pembelajarannya ke-4 (SnoWBel IV), Universitas Negeri Malang (UM). DOI: https://dx.doi.org/10.13140/RG.2.2.21931.39206

Setiawan, Adib Rifqi. (2019, October 14). Penyusunan Program Pembelajaran Biologi Berorientasi Literasi Saintifik. Seminar Nasional Sains \& Entrepreneurship VI (SNSE VI): 255-1-8. URL:

http://conference.upgris.ac.id/index.php/snse/article/view/255

Setiawan, Adib Rifqi. (2019, October 8). Biografi Clara Ng Perempuan Penulis Asal Indonesia. PsyArXiv. DOI: https://doi.org/10.31234/osf.io/yk8sx

Setiawan, Adib Rifqi. (2019, September 30). Instrumen Penilaian untuk Pembelajaran Ekologi Berorientasi Literasi Saintifik. Assimilation: Indonesian Journal of Biology Education, 02(02): 42-46. DOI: https://dx.doi.org/10.17509/aijbe.v2i2.19250

Setiawan, Adib Rifqi. (2020, April 1). Sharifah Halimah Alaydrus. Thesis Commons. DOI: https://doi.org/10.31237/osf.io/fp79c

Setiawan, Adib Rifqi. (2020, April 1). Syarifah Halimah Alaydrus. Thesis Commons. DOI: https://doi.org/10.31237/osf.io/xbmcs

Setiawan, Adib Rifqi. (2020, April 13). Commodification of the Sexuality in Kim Kardashian's Instagram Posts. Thesis Commons. URL: https://thesiscommons.org/mf7nw/

Setiawan, Adib Rifqi. (2020, April 13). مبادئ اللغة العربية. Thesis Commons. DOI: https://doi.org/10.31237/osf.io/2gvjf

Setiawan, Adib Rifqi. (2020, April 14). Commodification of the Sexuality in Kim Kardashian's Instagram Posts. SocArXiv. DOI: https://doi.org/10.31235/osf.io/kd6au

Setiawan, Adib Rifqi. (2020, April 14). Jalāl al-Dīn 'Abd al-Roḥmān ibn Abī Bakr al-Suyūṭ̣̂. SocArXiv. DOI: https://doi.org/10.31235/osf.io/5zf9v 
Setiawan, Adib Rifqi. (2020, April 18). Musyāfahah al-Qur’ān Melalui Media Elektronik. Thesis Commons. URL: https://thesiscommons.org/ntjp9/

Setiawan, Adib Rifqi. (2020, April 2). Desain Pembelajaran untuk Membimbing Siswa Sekolah Dasar dalam Memperoleh Literasi Saintifik. EdArXiv. DOI: https://doi.org/10.35542/osf.io/u59f8

Setiawan, Adib Rifqi. (2020, April 2). JUPE My Uncut Story. Open Science Framework (OSF). DOI: https://doi.org/10.31219/osf.io/qdxga

Setiawan, Adib Rifqi. (2020, April 2). What is the Best Way to Analyze Pre-Post Data?. EdArXiv. DOI: https://doi.org/10.35542/osf.io/h4e6q

Setiawan, Adib Rifqi. (2020, April 20). Menyusun Instrumen Penilaian untuk Pembelajaran Ekologi Berorientasi Literasi Saintifik. Prosiding Seminar Nasional dan Workshop Biologi-IP A dan Pembelajaran Ke-4 (SnoWBel IV): 241-9. ISBN : 978-602-470-1703 \& e-ISBN : 978-602-470-171-0.

Setiawan, Adib Rifqi. (2020, April 21). Lembar Kegiatan Literasi Saintifik untuk Pembelajaran Jarak Jauh Topik Penyakit Coronavirus 2019 (COVID-19). Edukatif: Jumal Ilmu Pendidikan, 02(01): 28-37. DOI: https://doi.org/10.31004/edukatif.v2i1.80

Setiawan, Adib Rifqi. (2020, April 3). Sharifah Halimah Alaydrus : a female preachers for our time. SocArXiv. DOI: https://doi.org/10.31235/osf.io/zb8qe

Setiawan, Adib Rifqi. (2020, April 4). Grace Natalie Louisa. SocArXiv. DOI: https://doi.org/10.31235/osf.io/zwf6g

Setiawan, Adib Rifqi. (2020, April 4). Grace Natalie Louisa. Thesis Commons. DOI: https://doi.org/10.31237/osf.io/u3mxv

Setiawan, Adib Rifqi. (2020, April 5). The Arrogant One. Thesis Commons. DOI: https://doi.org/10.31237/osf.io/8nmku

Setiawan, Adib Rifqi. (2020, April 9). Islamic Education in Southeast Asia. EdArXiv. DOI: https://doi.org/10.35542/osf.io/dnjqv

Setiawan, Adib Rifqi. (2020, April 9). Islamic Education in Southeast Asia. Thesis Commons. DOI: https://doi.org/10.31237/osf.io/e794d

Setiawan, Adib Rifqi. (2020, February 18). Menyusun Instrumen Penilaian untuk Pembelajaran Topik Lingkungan Berorientasi Literasi Saintifik. Prosiding Seminar Nasional Fisika (SiNaFi) 2019: 15-21. URL:

http://proceedings.upi.edu/index.php/sinafi/article/view/563

Setiawan, Adib Rifqi. (2020, January 17). Penerapan Pendekatan Saintifik dalam Pembelajaran Biologi sebagai Upaya Melatih Literasi Saintifik. Prosiding Seminar Nasional Biologi 2019 Inovasi Penelitian dan Pembelajaran Biologi III (IP2B III): 140-145. URL: http://semnasbiologi.conference.unesa.ac.id/ocs/index.php/semnasbio/IP2BII I/paper/viewFile/6/19

Setiawan, Adib Rifqi. (2020, January 17). Penggunaan Mabadi 'Asyroh dalam Pembelajaran Biologi untuk Meningkatkan Motivasi dan Hasil Belajar. Prosiding Seminar Nasional Biologi 2019 Inovasi Penelitian dan Pembelajaran Biologi III (IP2B III): 158164. URL:

http://semnasbiologi.conference.unesa.ac.id/ocs/index.php/semnasbio/IP2BII I/paper/viewFile/11/21

Setiawan, Adib Rifqi. (2020, January 17). Upaya Meningkatkan Motivasi Belajar dalam Pembelajaran Ilmu Pengetahuan Alam (IPA) Melalui Bacaan Populer. Prosiding Seminar Nasional Biologi 2019 Inovasi Penelitian dan Pembelajaran Biologi III (IP2B III): 154-157. URL:

http://semnasbiologi.conference.unesa.ac.id/ocs/index.php/semnasbio/IP2BII I/paper/viewFile/5/51 
Setiawan, Adib Rifqi. (2020, January 24). Pembelajaran Tematik Berorientasi Literasi Saintifik. Jurnal Basicedu: Journal of Elementary Education, 04(01): 71-80. URL: https://jbasic.org/index.php/basicedu/article/view/298

Setiawan, Adib Rifqi. (2020, March 01). Pendidikan Literasi Finansial Melalui Pembelajaran Fiqh Mu'āmalāt Berbasis Kitab Kuning. Ną̧hruna: Jurnal Pendidikan Islam, 03(01): 138-159. DOI: https://dx.doi.org/10.31538/nzh.v3i1.522

Setiawan, Adib Rifqi. (2020, May 12). Introducing the Indonesian Education System. Thesis Commons. DOI: https://doi.org/10.31237/osf.io/ygt5c

Setiawan, Adib Rifqi. (2020, May 6). Discovering the Meaning of Fadhilaturrahmi's Work. Thesis Commons. DOI: https://doi.org/10.31237/osf.io/krf7z

Setiawan, Adib Rifqi. (2020, May 6). Menyibak Makna Karya Fadhilaturrahmi. LIS Scholarship Archive. DOI: https://doi.org/10.31229/osf.io/65y4z

Setiawan, Adib Rifqi; \& Ilmiyah, Surotul. (2020, April 13). Kecerdasan Majemuk Berdasarkan Neurosains. EdArXiv. DOI: https://doi.org/10.35542/osf.io/rj2fe

Setiawan, Adib Rifqi; \& Ilmiyah, Surotul. (2020, April 13). Multiple Intelligences Based on Neuroscience. Thesis Commons. DOI: https://doi.org/10.31237/osf.io/e9fyu

Setiawan, Adib Rifqi; \& Ilmiyah, Surotul. (2020, April 7). Lembar Kegiatan Siswa untuk Pembelajaran Jarak Jauh Berdasarkan Literasi Saintifik pada Topik Penyakit Coronavirus 2019 (COVID-19). EdArXiv. DOI: https://doi.org/10.35542/osf.io/h4632

Setiawan, Adib Rifqi; Mufassaroh, Arij Zulfi. (2019, June 28). Menyusun Soal Literasi Saintifik untuk Pembelajaran Biologi Topik Plantae dan Animalia. BIOSFER: Jurnal Biologi dan Pendidikan Biologi, 04(01): 33-40. URL: http://dx.doi.org/10.23969/biosfer.v4i1.1484

Setiawan, Adib Rifqi; Puspaningrum, Mita; Umam, Khoirul. (2019, December 06). Pembelajaran Fiqh Mu'āmalāt Berorientasi Literasi Finansial. Tarbany: Indonesian Journal of Islamic Education, 06(02): 187-102. URL: https://ejournal.upi.edu/index.php/tarbawy/article/view/20887

Setiawan, Adib Rifqi; Saputri, Wahyu EKa. (2020, December 10). Pembelajaran Literasi Saintifik untuk Pendidikan Dasar. Media Penelitian Pendidikan : Jurnal Penelitian dalam Bidang Pendidikan dan Pengajaran, 14(02). DOI: https://doi.org/10.26877/mpp.v14i2.5794

Setiawan, Adib Rifqi; Saputri, Wahyu EKa. (2020, June 13). Science Motivation Questionnaire II (SMQ II) Versi Bahasa Indonesia. Psy ArXiv. DOI: https://doi.org/10.31234/osf.io/tac2k

Setiawan, Adib Rifqi; Utari, Setiya; Nugraha, Muhamad Gina. (2016, December 17). Mengonstruksi Rancangan Soal Domain Kompetensi Literasi Saintifik Siswa SMP Kelas VIII pada Topik Gerak Lurus. Seminar Nasional Fisika ke-2 (SiNaFi II), Universitas Pendidikan Indonesia (UPI). DOI: https://dx.doi.org/10.13140/RG.2.2.31856.10246/1

Setiawan, Adib Rifqi; Utari, Setiya; Nugraha, Muhamad Gina. (2017, September 22). Mengonstruksi Rancangan Soal Domain Kompetensi Literasi Saintifik Siswa SMP Kelas VIII pada Topik Gerak Lurus. Wabana Pendidikan Fisika, 02(02): 44 48. URL: https:// ejournal.upi.edu/index.php/WPF/article/view/8277/0

Siayah, Syarofis; \& Setiawan, Adib Rifqi. (2020, April 13). A Brief Explanation of Science Education. EdArXiv. DOI: https://doi.org/10.35542/osf.io/2evn3

Siayah, Syarofis; \& Setiawan, Adib Rifqi. (2020, April 13). A Brief Explanation of Science Education. Thesis Commons. DOI: https://doi.org/10.31237/osf.io/wkvsn Velasufah, Whasfi; \& Setiawan, Adib Rifqi. (2020, April 13). Nilai Pesantren Sebagai Dasar Pendidikan Karakter. Thesis Commons. DOI: https://doi.org/10.31237/osf.io/hq6kz 
Amatullah; \& Setiawan, Adib Rifqi. (2017, October 10). Nadirsyah Hosen: berkarya sebagai diaspora. Majalab SANTRI, 7: 56-59. URL:

https://issuu.com/majalahsantri/docs/santri_edisi_7/58

Feldman, DarHalevy; \& Setiawan, Adib Rifqi. (2020, April 24). Education in Israel. Thesis Commons. DOI: https://doi.org/10.31237/osf.io/62shg

Ilmiyah, Surotul; \& Setiawan, Adib Rifqi. (2020, April 7). Students' Worksheet for Distance Learning Based on Scientific Literacy in the Topic Coronavirus Disease 2019 (COVID-19). Thesis Commons. DOI: https://doi.org/10.31237/osf.io/fpg4j

Ilmiyah, Surotul; \& Setiawan, Adib Rifqi. (2020, April 7). Students' Worksheet for Distance Learning Based on Scientific Literacy in the Topic Coronavirus Disease 2019 (COVID-19). EdArXiv. DOI: https://doi.org/10.35542/osf.io/wyz5v

Setiawan, A. R. (2020, May 7). Discovering the Fundamental Problem of Four Methods to Analyze Data. Thesis Commons. DOI: https://doi.org/10.31237/osf.io/h953y

Setiawan, Adib Rifqi. (2015, November 03). Dibalik Nama Besar Albert Einstein: Dari Politik, Asmara, hingga Matematika. fisikanet.lipi.go.id. URL: http://www.fisikanet.lipi.go.id/utama.cgi?artikel\&1446556354\&2

Setiawan, Adib Rifqi. (2015, November 07). Dibalik Sampul Buku A Brief History of Time, agar pengetahuan tak hanya dinikmati ilmuwan. fisikanet.lipi.go.id. URL: http://www.fisikanet.lipi.go.id/utama.cgi?artikel\&1446855103\&2

Setiawan, Adib Rifqi. (2015, November 10). Kehidupan Asmara Hawking: raga lumpuh, jiwa masih bisa tersentuh. fisikanet.lipi.go.id. URL: http://www.fisikanet.lipi.go.id/utama.cgi?artikel\&1447145876\&2

Setiawan, Adib Rifqi. (2015, October 10). 10 Kejutan Subatomik. fisikanet.lipi.go.id. URL: http://www.fisikanet.lipi.go.id/utama.cgi?artikel\&1444577286\&3

Setiawan, Adib Rifqi. (2015, October 31). Kurir Mikroskopis Alam Semesta bukan debu biasa. fisikanet.lipi.go.id. URL: http://www.fisikanet.lipi.go.id/utama.cgi?artikel\&1446304060\&2

Setiawan, Adib Rifqi. (2017, February 24). Penerapan Pendekatan Saintifik untuk Melatibkan Literasi Saintifik dalam Domain Kompetensi pada Topik Gerak Lurus di Sekolah Menengah Pertama. Undergraduate Thesis. Bandung: Universitas Pendidikan Indonesia. URL: http://repository.upi.edu/29074/

Setiawan, Adib Rifqi. (2017, June 02). Aisha. qureta.com. URL: https://www.qureta.com/next/post/aisha-humaira

Setiawan, Adib Rifqi. (2017, June 03). Dari Yuli Hingga Julia. qureta.com. URL: https://www.qureta.com/next/post/dari-yuli-hingga-julia-2

Setiawan, Adib Rifqi. (2018, April 10). Busana: pemantas raga, pelaras jiwa. Majalah SANTRI, 8: 26-27. URL: https://issuu.com/majalahsantri/docs/majalah_santri_8/28

Setiawan, Adib Rifqi. (2018, April 10). Eny Rochmawati Octaviani: memberikan hiburan, menyuntikkan harapan. Majalah SANTRI, 8: 15-18. URL: https://issuu.com/majalahsantri/docs/majalah_santri_8/17

Setiawan, Adib Rifqi. (2018, April 10). Rosa Amalia Iqony: paduan yakin diri dan rendah hati. Majalab SANTRI, 8: 46. URL: https://issuu.com/majalahsantri/docs/majalah_santri_8/48

Setiawan, Adib Rifqi. (2018, December 18). Irma Rahma Suwarma. qureta.com. URL: https://www.qureta.com/next/post/irma-rahma-suwarma

Setiawan, Adib Rifqi. (2018, July 03). Tangis Daniela Hantuchová. qureta.com. URL: https://www.qureta.com/next/post/tangis-daniela-hantuchova

Setiawan, Adib Rifqi. (2018, July 16). Rustriningsih, Srikandi Tersisih. qureta.com. URL: https://www.qureta.com/next/post/rustriningsih-srikandi-tersisih

Setiawan, Adib Rifqi. (2018, June 27). Ice. qureta.com. URL: https://www.qureta.com/next/post/ice 
Setiawan, Adib Rifqi. (2018, June 28). Dewi Perssik. qureta.com. URL: https://www.qureta.com/next/post/dewi-perssik

Setiawan, Adib Rifqi. (2018, March 06). Breast Capital. qureta.com. URL: https://www.qureta.com/next/post/breast-capital

Setiawan, Adib Rifqi. (2018, March 06). Menyoal Vokal Duo Serigala. qureta.com. URL: https://www.qureta.com/next/post/menyoal-vokal-duo-serigala

Setiawan, Adib Rifqi. (2018, March 07). Mengenal Oza Kioza. qureta.com. URL: https://www.qureta.com/next/post/mengenal-oza-kioza

Setiawan, Adib Rifqi. (2018, March 09). Asal Usul Nama Via Vallen. qureta.com. URL: https://www.qureta.com/next/post/asal-usul-nama-via-vallen

Setiawan, Adib Rifqi. (2018, March 09). Kepedulian Airin Rachmi Diany pada Pendidikan. qureta.com. URL: https://www.qureta.com/next/post/kepedulian-airin-rachmidiany-pada-pendidikan

Setiawan, Adib Rifqi. (2018, March 09). Ketika YoonA Menyaksikan Real Madrid Menghempaskan PSG. qureta.com. URL:

https://www.qureta.com/next/post/ketika-yoona-menyaksikan-real-madridmenghempaskan-psg

Setiawan, Adib Rifqi. (2018, March 09). Laila Fariha Zein (a.k.a. Uus atau Febi). qureta.com. URL: https://www.qureta.com/next/post/laila-fariha-zein-febi

Setiawan, Adib Rifqi. (2018, March 09). Pantat Perekat Umat. qureta.com. URL: https://www.qureta.com/next/post/pantat-perekat-umat

Setiawan, Adib Rifqi. (2018, March 09). Sisi Religi Grace Natalie. qureta.com. URL: https://www.qureta.com/next/post/sisi-religi-grace-natalie

Setiawan, Adib Rifqi. (2018, March 10). Venice Min. qureta.com. URL: https://www.qureta.com/next/post/venice-min

Setiawan, Adib Rifqi. (2018, March 11). Kisah Kasih Ayah di Balik Mata Najwa. qureta.com. URL: https://www.qureta.com/next/post/kisah-kasih-ayah-di-balik-mata-najwa

Setiawan, Adib Rifqi. (2018, March 11). Rosa Amalia Iqony. qureta.com. URL: https://www.qureta.com/next/post/rosa-amalia-iqony

Setiawan, Adib Rifqi. (2018, March 12). Clara Ng. qureta.com. URL: https://www.qureta.com/next/post/clara-ng

Setiawan, Adib Rifqi. (2018, March 14). Meniti Ilmuwati. qureta.com. URL: https://www.qureta.com/next/post/meniti-ilmuwati

Setiawan, Adib Rifqi. (2018, March 14). Surely You're Joking, Mrs. Ilmy!. qureta.com. URL: https://www.qureta.com/next/post/surely-you-re-joking-mrs-ilmy

Setiawan, Adib Rifqi. (2018, March 15). Eny R. Octaviani. qureta.com. URL: https://www.qureta.com/next/post/eny-r-octaviani

Setiawan, Adib Rifqi. (2018, March 17). Maryam Musfiroh: An Educator for Our Time. qureta.com. URL: https://www.qureta.com/next/post/maryam-musfiroh-aneducator-for-our-time

Setiawan, Adib Rifqi. (2018, March 19). Airin Rachmi Diany, Lilin Penerang Masyarakat Urban. qureta.com. URL: https://www.qureta.com/next/post/airin-rachmi-diany-lilinpenerang-masyarakat-urban

Setiawan, Adib Rifqi. (2018, March 19). Guru yang Menyapih: Catatan Perjalanan Pribadi Nong Darol Mahmada. qureta.com. URL: https://www.qureta.com/next/post/guruyang-menyapih-catatan-perjalanan-pribadi-nong-darol-mahmada

Setiawan, Adib Rifqi. (2018, March 19). Kamu dalam Aku: A Brief Story of Park Bom. qureta.com. URL: https://www.qureta.com/next/post/kamu-dalam-aku-a-brief-storyof-park-bom 
Setiawan, Adib Rifqi. (2018, March 21). Bidadari di Kesunyian itu Bernama Maria Sharapova. qureta.com. URL: https://www.qureta.com/next/post/bidadari-di-kesunyianitu-bernama-maria-sharapova

Setiawan, Adib Rifqi. (2018, March 25). Novi Kaka: Sahabat, Panutan, Pembimbing. qureta.com. URL: https://www.qureta.com/next/post/novi-kaka-sahabat-panutanpembimbing

Setiawan, Adib Rifqi. (2018, May 24). Fakhrun. qureta.com. URL: https://www.qureta.com/next/post/fakhrun

Setiawan, Adib Rifqi. (2018, November 24). Penerapan Pendekatan Saintifik untuk Melatih Literasi Saintifik dalam Domain Kompetensi pada Topik Gerak Lurus di Sekolah Menengah Pertama. Seminar Nasional Fisika ke-4 (SiNaFi IV), Universitas Pendidikan Indonesia (UPI). DOI: https://dx.doi.org/10.13140/RG.2.2.23154.04809

Setiawan, Adib Rifqi. (2018, October 05). Karen Armstrong. qureta.com. URL: https://www.qureta.com/next/post/karen-armstrong

Setiawan, Adib Rifqi. (2018, September 17). Lola Zieta Azelien. qureta.com. URL: https://www.qureta.com/next/post/lola-zieta-azelien

Setiawan, Adib Rifqi. (2019, August 21). Penyusunan Program Pembelajaran Biologi Berorientasi Literasi Saintifik. Seminar Nasional Sains \& Entrepreneurship VI (SNSE VI), Universitas PGRI Semarang (UPGRIS). DOI: https://dx.doi.org/10.13140/RG.2.2.13716.86400

Setiawan, Adib Rifqi. (2019, December 20). Literasi Saintifik Berdasarkan Kecerdasan Majemuk dan Motivasi Belajar. Media Penelitian Pendidikan: Jurnal Penelitian dalam Bidang Pendidikan dan Pengajaran, 13(02): 126-137. DOI: http://dx.doi.org/10.26877/mpp.v13i2.4913

Setiawan, Adib Rifqi. (2019, December 23). Contoh Langkah Pembelajaran Berorientasi Literasi Saintifik. santrimilenial.net. URL: https://santrimilenial.net/contoh-langkahpembelajaran-berorientasi-literasi-saintifik/

Setiawan, Adib Rifqi. (2019, December 30). Instrumen Penilaian Pembelajaran Fiqh Mu'āmalāt Berorientasi Literasi Finansial. Eklektik: Jurnal Pendidikan Ekonomi dan Kewirausahaan, 02(02): 258-272. DOI: http://dx.doi.org/10.24014/ekl.v2i2.8117

Setiawan, Adib Rifqi. (2019, June 14). Deasy Noviyanti, Perempuan Berbadan Defisit Lemak. qureta.com. URL: https://www.qureta.com/next/post/deasy-noviyantiperempuan-berbadan-defisit-lemak

Setiawan, Adib Rifqi. (2019, June 26). Peningkatan Literasi Saintifik melalui Pembelajaran Biologi Menggunakan Pendekatan Saintifik. Journal of Biology Education, 02(01): 223-235.

URL: http://journal.stainkudus.ac.id/index.php/jbe/article/view/5278

Setiawan, Adib Rifqi. (2019, March 23). Penerapan Pendekatan Saintifik dalam Pembelajaran Biologi sebagai Upaya Melatih Literasi Saintifik Siswa Sekolah Menengah. Seminar Nasional Biologi 2019 Inovasi Penelitian dan Pembelajaran Biologi III (IP2B III), Universitas Negeri Surabaya (UNESA). DOI: https://dx.doi.org/10.13140/RG.2.2.19798.60484

Setiawan, Adib Rifqi. (2019, March 23). Penggunaan Naḍom Mabāī'‘Asyroh dalam Pembelajaran Biologi untuk Meningkatkan Motivasi dan Hasil Belajar. Seminar Nasional Biologi 2019 Inovasi Penelitian dan Pembelajaran Biologi III (IP2B III), Universitas Negeri Surabaya (UNESA). DOI: https://dx.doi.org/10.13140/RG.2.2.33220.37763

Setiawan, Adib Rifqi. (2019, March 23). Upaya Meningkatkan Motivasi Belajar dalam Pembelajaran Ilmu Pengetahuan Alam (IPA) Melalui Bacaan Populer. Seminar Nasional Biologi 2019 Inovasi Penelitian dan Pembelajaran Biologi III (IP2B III), 
Universitas Negeri Surabaya (UNESA). DOI:

https://dx.doi.org/10.13140/RG.2.2.13087.71847

Setiawan, Adib Rifqi. (2019, May 07). Penerapan Pendekatan Saintifik untuk Melatih Literasi Saintifik dalam Domain Kompetensi pada Topik Gerak Lurus di Sekolah Menengah Pertama. Prosiding Seminar Nasional Fisika (SiNaFi) 2018: 7-13. URL: http://proceedings.upi.edu/index.php/sinafi/article/view/355

Setiawan, Adib Rifqi. (2019, November 23). Analisis Keabsahan dan Keandalan Science Motivation Questionnaire II (SMQ II) Versi Bahasa Indonesia. Seminar Nasional Fisika $V(\mathrm{SiNaFi}$ 5.0), Universitas Pendidikan Indonesia (UPI). DOI: https://doi.org/10.31237/osf.io/6zeph

Setiawan, Adib Rifqi. (2019, November 23). Menyusun Instrumen Penilaian untuk Pembelajaran Topik Lingkungan Berorientasi Literasi Saintifik. Seminar Nasional Fisika $V$ (SiNaFi 5.0), Universitas Pendidikan Indonesia (UPI). DOI: https://dx.doi.org/10.35542/osf.io/sc6d2

Setiawan, Adib Rifqi. (2019, November 23). Profil Literasi Saintifik Berdasarkan Kecerdasan Majemuk dan Motivasi Belajar. Seminar Nasional Fisika V (SiNaFi 5.0), Universitas Pendidikan Indonesia (UPI). DOI: https://dx.doi.org/10.35542/osf.io/m7n95

Setiawan, Adib Rifqi. (2019, October 02). Efektivitas Pembelajaran Biologi Berorientasi Literasi Saintifik. Thabiea : Journal of Natural Science Teaching, 02 (02): 83-94. DOI: http://dx.doi.org/10.21043/thabiea.v2i2.5345

Setiawan, Adib Rifqi. (2019, October 05). Menyusun Instrumen Penilaian untuk Pembelajaran Ekologi Berorientasi Literasi Saintifik. Seminar Nasional \& Workshop Biologi, IPA, dan Pembelajarannya ke-4 (SnoWBel IV), Universitas Negeri Malang (UM). DOI: https://dx.doi.org/10.13140/RG.2.2.21931.39206

Setiawan, Adib Rifqi. (2019, October 14). Penyusunan Program Pembelajaran Biologi Berorientasi Literasi Saintifik. Seminar Nasional Sains \& Entrepreneurship VI (SNSE VI): 255-1-8. URL: http:// conference.upgris.ac.id/index.php/snse/article/view/255

Setiawan, Adib Rifqi. (2019, October 8). Biografi Clara Ng Perempuan Penulis Asal Indonesia. Psy/ArXiv. DOI: https://doi.org/10.31234/osf.io/yk8sx

Setiawan, Adib Rifqi. (2019, September 30). Instrumen Penilaian untuk Pembelajaran Ekologi Berorientasi Literasi Saintifik. Assimilation: Indonesian Journal of Biology Education, 02(02): 42-46. DOI: https://dx.doi.org/10.17509/aijbe.v2i2.19250

Setiawan, Adib Rifqi. (2020, April 1). Sharifah Halimah Alaydrus. Thesis Commons. DOI: https://doi.org/10.31237/osf.io/fp79c

Setiawan, Adib Rifqi. (2020, April 1). Syarifah Halimah Alaydrus. Thesis Commons. DOI: https://doi.org/10.31237/osf.io/xbmcs

Setiawan, Adib Rifqi. (2020, April 13). Commodification of the Sexuality in Kim Kardashian's Instagram Posts. Thesis Commons. URL: https://thesiscommons.org/mf7nw/

Setiawan, Adib Rifqi. (2020, April 13). مبادئ اللغة العربية. Thesis Commons. DOI: https://doi.org/10.31237/osf.io/2gvjf

Setiawan, Adib Rifqi. (2020, April 14). Commodification of the Sexuality in Kim Kardashian's Instagram Posts. SocArXiv. DOI: https://doi.org/10.31235/osf.io/kd6au

Setiawan, Adib Rifqi. (2020, April 14). Jalāl al-Dīn 'Abd al-Roḥmān ibn Abī Bakr al-Suyūṭị. SocArXiv. DOI: https://doi.org/10.31235/osf.io/5zf9v

Setiawan, Adib Rifqi. (2020, April 18). Musyāfahah al-Qur'ān Melalui Media Elektronik. Thesis Commons. URL: https://thesiscommons.org/ntjp9/

Setiawan, Adib Rifqi. (2020, April 2). Desain Pembelajaran untuk Membimbing Siswa Sekolah Dasar dalam Memperoleh Literasi Saintifik. EdArXiv. DOI: https://doi.org/10.35542/osf.io/u59f8 
Setiawan, Adib Rifqi. (2020, April 2). JUPE My Uncut Story. Open Science Framework (OSF). DOI: https://doi.org/10.31219/osf.io/qdxga

Setiawan, Adib Rifqi. (2020, April 2). What is the Best Way to Analyze Pre-Post Data?.

EdArXiv. DOI: https://doi.org/10.35542/osf.io/h4e6q

Setiawan, Adib Rifqi. (2020, April 20). Menyusun Instrumen Penilaian untuk Pembelajaran Ekologi Berorientasi Literasi Saintifik. Prosiding Seminar Nasional dan Workshop Biologi-IP A dan Pembelajaran Ke-4 (SnoWBel IV): 241-9. ISBN : 978-602-470-1703 \& e-ISBN : 978-602-470-171-0.

Setiawan, Adib Rifqi. (2020, April 21). Lembar Kegiatan Literasi Saintifik untuk Pembelajaran Jarak Jauh Topik Penyakit Coronavirus 2019 (COVID-19). Edukatif: Jurnal Ilmu Pendidikan, 02(01): 28-37. DOI: https://doi.org/10.31004/edukatif.v2i1.80

Setiawan, Adib Rifqi. (2020, April 3). Sharifah Halimah Alaydrus : a female preachers for our time. SocArXiv. DOI: https://doi.org/10.31235/osf.io/zb8qe

Setiawan, Adib Rifqi. (2020, April 4). Grace Natalie Louisa. SocArXiv. DOI: https://doi.org/10.31235/osf.io/zwf6g

Setiawan, Adib Rifqi. (2020, April 4). Grace Natalie Louisa. Thesis Commons. DOI: https://doi.org/10.31237/osf.io/u3mxv

Setiawan, Adib Rifqi. (2020, April 5). The Arrogant One. Thesis Commons. DOI: https://doi.org/10.31237/osf.io/8nmku

Setiawan, Adib Rifqi. (2020, April 9). Islamic Education in Southeast Asia. EdArXiv. DOI: https://doi.org/10.35542/osf.io/dnjqv

Setiawan, Adib Rifqi. (2020, April 9). Islamic Education in Southeast Asia. Thesis Commons. DOI: https://doi.org/10.31237/osf.io/e794d

Setiawan, Adib Rifqi. (2020, February 18). Menyusun Instrumen Penilaian untuk Pembelajaran Topik Lingkungan Berorientasi Literasi Saintifik. Prosiding Seminar Nasional Fisika (SiNaFi) 2019: 15-21. URL:

http://proceedings.upi.edu/index.php/sinafi/article/view/563

Setiawan, Adib Rifqi. (2020, January 17). Penerapan Pendekatan Saintifik dalam Pembelajaran Biologi sebagai Upaya Melatih Literasi Saintifik. Prosiding Seminar Nasional Biologi 2019 Inovasi Penelitian dan Pembelajaran Biologi III (IP2B III): 140-145. URL: http://semnasbiologi.conference.unesa.ac.id/ocs/index.php/semnasbio/IP2BII I/paper/viewFile/6/19

Setiawan, Adib Rifqi. (2020, January 17). Penggunaan Mabadi 'Asyroh dalam Pembelajaran Biologi untuk Meningkatkan Motivasi dan Hasil Belajar. Prosiding Seminar Nasional Biologi 2019 Inovasi Penelitian dan Pembelajaran Biologi III (IP2B III): 158164. URL:

http://semnasbiologi.conference.unesa.ac.id/ocs/index.php/semnasbio/IP2BII I/paper/viewFile/11/21

Setiawan, Adib Rifqi. (2020, January 17). Upaya Meningkatkan Motivasi Belajar dalam Pembelajaran Ilmu Pengetahuan Alam (IPA) Melalui Bacaan Populer. Prosiding Seminar Nasional Biologi 2019 Inovasi Penelitian dan Pembelajaran Biologi III (IP2B III): 154-157. URL:

http://semnasbiologi.conference.unesa.ac.id/ocs/index.php/semnasbio/IP2BII $\mathrm{I} /$ paper/viewFile/5/51

Setiawan, Adib Rifqi. (2020, January 24). Pembelajaran Tematik Berorientasi Literasi Saintifik. Jurnal Basicedu: Journal of Elementary Education, 04(01): 71-80. URL: https://jbasic.org/index.php/basicedu/article/view/298

Setiawan, Adib Rifqi. (2020, March 01). Pendidikan Literasi Finansial Melalui Pembelajaran Fiqh Mu'āmalāt Berbasis Kitab Kuning. Ną̧hruna: Jurnal Pendidikan Islam, 03(01): 138-159. DOI: https://dx.doi.org/10.31538/nzh.v3i1.522 
Setiawan, Adib Rifqi. (2020, May 12). Introducing the Indonesian Education System. Thesis Commons. DOI: https://doi.org/10.31237/osf.io/ygt5c

Setiawan, Adib Rifqi. (2020, May 6). Discovering the Meaning of Fadhilaturrahmi's Work. Thesis Commons. DOI: https://doi.org/10.31237/osf.io/krf7z

Setiawan, Adib Rifqi. (2020, May 6). Menyibak Makna Karya Fadhilaturrahmi. LIS Scholarship Archive. DOI: https://doi.org/10.31229/osf.io/65y4z

Setiawan, Adib Rifqi; \& Ilmiyah, Surotul. (2020, April 13). Kecerdasan Majemuk Berdasarkan Neurosains. EdArXiv. DOI: https://doi.org/10.35542/osf.io/rj2fe

Setiawan, Adib Rifqi; \& Ilmiyah, Surotul. (2020, April 13). Multiple Intelligences Based on Neuroscience. Thesis Commons. DOI: https://doi.org/10.31237/osf.io/e9fyu

Setiawan, Adib Rifqi; \& Ilmiyah, Surotul. (2020, April 7). Lembar Kegiatan Siswa untuk Pembelajaran Jarak Jauh Berdasarkan Literasi Saintifik pada Topik Penyakit Coronavirus 2019 (COVID-19). EdArXiv. DOI: https://doi.org/10.35542/osf.io/h4632

Setiawan, Adib Rifqi; Mufassaroh, Arij Zulfi. (2019, June 28). Menyusun Soal Literasi Saintifik untuk Pembelajaran Biologi Topik Plantae dan Animalia. BIOSFER: Jurnal Biologi dan Pendidikan Biologi, 04(01): 33-40. URL: http://dx.doi.org/10.23969/biosfer.v4i1.1484

Setiawan, Adib Rifqi; Puspaningrum, Mita; Umam, Khoirul. (2019, December 06). Pembelajaran Fiqh Mu'āmalāt Berorientasi Literasi Finansial. Tarbawy: Indonesian Journal of Islamic Education, 06(02): 187-102. URL: https://ejournal.upi.edu/index.php/tarbawy/article/view/20887

Setiawan, Adib Rifqi; Saputri, Wahyu EKa. (2020, December 10). Pembelajaran Literasi Saintifik untuk Pendidikan Dasar. Media Penelitian Pendidikan : Jurnal Penelitian dalam Bidang Pendidikan dan Pengajaran, 14(02). DOI: https://doi.org/10.26877/mpp.v14i2.5794

Setiawan, Adib Rifqi; Saputri, Wahyu EKa. (2020, June 13). Science Motivation Questionnaire II (SMQ II) Versi Bahasa Indonesia. Psy ArXiv. DOI: https://doi.org/10.31234/osf.io/tac2k

Setiawan, Adib Rifqi; Utari, Setiya; Nugraha, Muhamad Gina. (2016, December 17). Mengonstruksi Rancangan Soal Domain Kompetensi Literasi Saintifik Siswa SMP Kelas VIII pada Topik Gerak Lurus. Seminar Nasional Fisika ke-2 (SiNaFi II), Universitas Pendidikan Indonesia (UPI). DOI: https://dx.doi.org/10.13140/RG.2.2.31856.10246/1

Setiawan, Adib Rifqi; Utari, Setiya; Nugraha, Muhamad Gina. (2017, September 22). Mengonstruksi Rancangan Soal Domain Kompetensi Literasi Saintifik Siswa SMP Kelas VIII pada Topik Gerak Lurus. Wahana Pendidikan Fisika, 02(02): 44 48. URL: https://ejournal.upi.edu/index.php/WPF/article/view/8277/0

Siayah, Syarofis; \& Setiawan, Adib Rifqi. (2020, April 13). A Brief Explanation of Science Education. EdArXiv. DOI: https://doi.org/10.35542/osf.io/2evn3

Siayah, Syarofis; \& Setiawan, Adib Rifqi. (2020, April 13). A Brief Explanation of Science Education. Thesis Commons. DOI: https://doi.org/10.31237/osf.io/wkvsn

Velasufah, Whasfi; \& Setiawan, Adib Rifqi. (2020, April 13). Nilai Pesantren Sebagai Dasar Pendidikan Karakter. Thesis Commons. DOI: https://doi.org/10.31237/osf.io/hq6kz

Amatullah; \& Setiawan, Adib Rifqi. (2017, October 10). Nadirsyah Hosen: berkarya sebagai diaspora. Majalab SANTRI, 7: 56-59. URL: https://issuu.com/majalahsantri/docs/santri_edisi_7/58

Feldman, DarHalevy; \& Setiawan, Adib Rifqi. (2020, April 24). Education in Israel. Thesis Commons. DOI: https://doi.org/10.31237/osf.io/62shg 
Ilmiyah, Surotul; \& Setiawan, Adib Rifqi. (2020, April 7). Students' Worksheet for Distance Learning Based on Scientific Literacy in the Topic Coronavirus Disease 2019 (COVID-19). Thesis Commons. DOI: https://doi.org/10.31237/osf.io/fpg4j

Ilmiyah, Surotul; \& Setiawan, Adib Rifqi. (2020, April 7). Students' Worksheet for Distance Learning Based on Scientific Literacy in the Topic Coronavirus Disease 2019 (COVID-19). EdArXiv. DOI: https://doi.org/10.35542/osf.io/wyz5v

Setiawan, A. R. (2020, May 7). Discovering the Fundamental Problem of Four Methods to Analyze Data. Thesis Commons. DOI: https://doi.org/10.31237/osf.io/h953y

Setiawan, Adib Rifqi. (2015, November 03). Dibalik Nama Besar Albert Einstein: Dari Politik, Asmara, hingga Matematika. fisikanet.lipi.go.id. URL: http://www.fisikanet.lipi.go.id/utama.cgi?artikel\&1446556354\&2

Setiawan, Adib Rifqi. (2015, November 07). Dibalik Sampul Buku A Brief History of Time, agar pengetahuan tak hanya dinikmati ilmuwan. fisikanet.lipi.go.id. URL: http://www.fisikanet.lipi.go.id/utama.cgi?artikel\&1446855103\&2

Setiawan, Adib Rifqi. (2015, November 10). Kehidupan Asmara Hawking: raga lumpuh, jiwa masih bisa tersentuh. fisikanet.lipi.go.id. URL: http://www.fisikanet.lipi.go.id/utama.cgi?artikel\&1447145876\&2

Setiawan, Adib Rifqi. (2015, October 10). 10 Kejutan Subatomik. fisikanet.lipi.go.id. URL: http://www.fisikanet.lipi.go.id/utama.cgi?artikel\&1444577286\&3

Setiawan, Adib Rifqi. (2015, October 31). Kurir Mikroskopis Alam Semesta bukan debu biasa. fisikanet.lipi.go.id. URL: http://www.fisikanet.lipi.go.id/utama.cgi?artikel\&1446304060\&2

Setiawan, Adib Rifqi. (2017, February 24). Penerapan Pendekatan Saintifik untuk Melatibkan Literasi Saintifik dalam Domain Kompetensi pada Topik Gerak Lurus di Sekolah Menengah Pertama. Undergraduate Thesis. Bandung: Universitas Pendidikan Indonesia. URL: http://repository.upi.edu/29074/

Setiawan, Adib Rifqi. (2017, June 02). Aisha. qureta.com. URL: https://www.qureta.com/next/post/aisha-humaira

Setiawan, Adib Rifqi. (2017, June 03). Dari Yuli Hingga Julia. qureta.com. URL: https://www.qureta.com/next/post/dari-yuli-hingga-julia-2

Setiawan, Adib Rifqi. (2018, April 10). Busana: pemantas raga, pelaras jiwa. Majalab SANTRI, 8: 26-27. URL: https://issuu.com/majalahsantri/docs/majalah_santri_8/28

Setiawan, Adib Rifqi. (2018, April 10). Eny Rochmawati Octaviani: memberikan hiburan, menyuntikkan harapan. Majalah SANTRI, 8: 15-18. URL: https://issuu.com/majalahsantri/docs/majalah_santri_8/17

Setiawan, Adib Rifqi. (2018, April 10). Rosa Amalia Iqony: paduan yakin diri dan rendah hati. Majalah SANTRI, 8: 46. URL:

https://issuu.com/majalahsantri/docs/majalah_santri_8/48

Setiawan, Adib Rifqi. (2018, December 18). Irma Rahma Suwarma. qureta.com. URL: https://www.qureta.com/next/post/irma-rahma-suwarma

Setiawan, Adib Rifqi. (2018, July 03). Tangis Daniela Hantuchová. qureta.com. URL: https://www.qureta.com/next/post/tangis-daniela-hantuchova

Setiawan, Adib Rifqi. (2018, July 16). Rustriningsih, Srikandi Tersisih. qureta.com. URL: https://www.qureta.com/next/post/rustriningsih-srikandi-tersisih

Setiawan, Adib Rifqi. (2018, June 27). Ice. qureta.com. URL: https://www.qureta.com/next/post/ice

Setiawan, Adib Rifqi. (2018, June 28). Dewi Perssik. qureta.com. URL: https://www.qureta.com/next/post/dewi-perssik

Setiawan, Adib Rifqi. (2018, March 06). Breast Capital. qureta.com. URL: https://www.qureta.com/next/post/breast-capital 
Setiawan, Adib Rifqi. (2018, March 06). Menyoal Vokal Duo Serigala. qureta.com. URL: https://www.qureta.com/next/post/menyoal-vokal-duo-serigala

Setiawan, Adib Rifqi. (2018, March 07). Mengenal Oza Kioza. qureta.com. URL: https://www.qureta.com/next/post/mengenal-oza-kioza

Setiawan, Adib Rifqi. (2018, March 09). Asal Usul Nama Via Vallen. qureta.com. URL: https://www.qureta.com/next/post/asal-usul-nama-via-vallen

Setiawan, Adib Rifqi. (2018, March 09). Kepedulian Airin Rachmi Diany pada Pendidikan. qureta.com. URL: https://www.qureta.com/next/post/kepedulian-airin-rachmidiany-pada-pendidikan

Setiawan, Adib Rifqi. (2018, March 09). Ketika YoonA Menyaksikan Real Madrid Menghempaskan PSG. qureta.com. URL:

https://www.qureta.com/next/post/ketika-yoona-menyaksikan-real-madridmenghempaskan-psg

Setiawan, Adib Rifqi. (2018, March 09). Laila Fariha Zein (a.k.a. Uus atau Febi). qureta.com. URL: https://www.qureta.com/next/post/laila-fariha-zein-febi

Setiawan, Adib Rifqi. (2018, March 09). Pantat Perekat Umat. qureta.com. URL: https://www.qureta.com/next/post/pantat-perekat-umat

Setiawan, Adib Rifqi. (2018, March 09). Sisi Religi Grace Natalie. qureta.com. URL: https://www.qureta.com/next/post/sisi-religi-grace-natalie

Setiawan, Adib Rifqi. (2018, March 10). Venice Min. qureta.com. URL: https://www.qureta.com/next/post/venice-min

Setiawan, Adib Rifqi. (2018, March 11). Kisah Kasih Ayah di Balik Mata Najwa. qureta.com. URL: https://www.qureta.com/next/post/kisah-kasih-ayah-di-balik-mata-najwa

Setiawan, Adib Rifqi. (2018, March 11). Rosa Amalia Iqony. qureta.com. URL: https://www.qureta.com/next/post/rosa-amalia-iqony

Setiawan, Adib Rifqi. (2018, March 12). Clara Ng. qureta.com. URL: https://www.qureta.com/next/post/clara-ng

Setiawan, Adib Rifqi. (2018, March 14). Meniti Ilmuwati. qureta.com. URL: https://www.qureta.com/next/post/meniti-ilmuwati

Setiawan, Adib Rifqi. (2018, March 14). Surely You're Joking, Mrs. Ilmy!. qureta.com. URL: https://www.qureta.com/next/post/surely-you-re-joking-mrs-ilmy

Setiawan, Adib Rifqi. (2018, March 15). Eny R. Octaviani. qureta.com. URL: https://www.qureta.com/next/post/eny-r-octaviani

Setiawan, Adib Rifqi. (2018, March 17). Maryam Musfiroh: An Educator for Our Time. qureta.com. URL: https://www.qureta.com/next/post/maryam-musfiroh-aneducator-for-our-time

Setiawan, Adib Rifqi. (2018, March 19). Airin Rachmi Diany, Lilin Penerang Masyarakat Urban. qureta.com. URL: https://www.qureta.com/next/post/airin-rachmi-diany-lilinpenerang-masyarakat-urban

Setiawan, Adib Rifqi. (2018, March 19). Guru yang Menyapih: Catatan Perjalanan Pribadi Nong Darol Mahmada. qureta.com. URL: https://www.qureta.com/next/post/guruyang-menyapih-catatan-perjalanan-pribadi-nong-darol-mahmada

Setiawan, Adib Rifqi. (2018, March 19). Kamu dalam Aku: A Brief Story of Park Bom. qureta.com. URL: https://www.qureta.com/next/post/kamu-dalam-aku-a-brief-storyof-park-bom

Setiawan, Adib Rifqi. (2018, March 21). Bidadari di Kesunyian itu Bernama Maria Sharapova. qureta.com. URL: https://www.qureta.com/next/post/bidadari-di-kesunyianitu-bernama-maria-sharapova

Setiawan, Adib Rifqi. (2018, March 25). Novi Kaka: Sahabat, Panutan, Pembimbing. qureta.com. URL: https://www.qureta.com/next/post/novi-kaka-sahabat-panutanpembimbing 
Setiawan, Adib Rifqi. (2018, May 24). Fakhrun. qureta.com. URL: https://www.qureta.com/next/post/fakhrun

Setiawan, Adib Rifqi. (2018, November 24). Penerapan Pendekatan Saintifik untuk Melatih Literasi Saintifik dalam Domain Kompetensi pada Topik Gerak Lurus di Sekolah Menengah Pertama. Seminar Nasional Fisika ke-4 (SiNaFi IV), Universitas Pendidikan Indonesia (UPI). DOI: https://dx.doi.org/10.13140/RG.2.2.23154.04809

Setiawan, Adib Rifqi. (2018, October 05). Karen Armstrong. qureta.com. URL: https://www.qureta.com/next/post/karen-armstrong

Setiawan, Adib Rifqi. (2018, September 17). Lola Zieta Azelien. qureta.com. URL: https://www.qureta.com/next/post/lola-zieta-azelien

Setiawan, Adib Rifqi. (2019, August 21). Penyusunan Program Pembelajaran Biologi Berorientasi Literasi Saintifik. Seminar Nasional Sains \& Entrepreneurship VI (SNSE VI), Universitas PGRI Semarang (UPGRIS). DOI: https://dx.doi.org/10.13140/RG.2.2.13716.86400

Setiawan, Adib Rifqi. (2019, December 20). Literasi Saintifik Berdasarkan Kecerdasan Majemuk dan Motivasi Belajar. Media Penelitian Pendidikan: Jurnal Penelitian dalam Bidang Pendidikan dan Pengajaran, 13(02): 126-137. DOI: http://dx.doi.org/10.26877/mpp.v13i2.4913

Setiawan, Adib Rifqi. (2019, December 23). Contoh Langkah Pembelajaran Berorientasi Literasi Saintifik. santrimilenial.net. URL: https://santrimilenial.net/contoh-langkahpembelajaran-berorientasi-literasi-saintifik/

Setiawan, Adib Rifqi. (2019, December 30). Instrumen Penilaian Pembelajaran Fiqh Mu'āmalāt Berorientasi Literasi Finansial. Eklektik: Jurnal Pendidikan Ekonomi dan Kewirausahaan, 02(02): 258-272. DOI: http://dx.doi.org/10.24014/ekl.v2i2.8117

Setiawan, Adib Rifqi. (2019, June 14). Deasy Noviyanti, Perempuan Berbadan Defisit Lemak. qureta.com. URL: https://www.qureta.com/next/post/deasy-noviyantiperempuan-berbadan-defisit-lemak

Setiawan, Adib Rifqi. (2019, June 26). Peningkatan Literasi Saintifik melalui Pembelajaran Biologi Menggunakan Pendekatan Saintifik. Journal of Biology Education, 02(01): 223-235.

URL: http://journal.stainkudus.ac.id/index.php/jbe/article/view/5278

Setiawan, Adib Rifqi. (2019, March 23). Penerapan Pendekatan Saintifik dalam Pembelajaran Biologi sebagai Upaya Melatih Literasi Saintifik Siswa Sekolah Menengah. Seminar Nasional Biologi 2019 Inovasi Penelitian dan Pembelajaran Biologi III (IP2B III), Universitas Negeri Surabaya (UNESA). DOI: https://dx.doi.org/10.13140/RG.2.2.19798.60484

Setiawan, Adib Rifqi. (2019, March 23). Penggunaan Naḍom Mabadī' 'Asyroh dalam Pembelajaran Biologi untuk Meningkatkan Motivasi dan Hasil Belajar. Seminar Nasional Biologi 2019 Inovasi Penelitian dan Pembelajaran Biologi III (IP2B III), Universitas Negeri Surabaya (UNESA). DOI: https://dx.doi.org/10.13140/RG.2.2.33220.37763

Setiawan, Adib Rifqi. (2019, March 23). Upaya Meningkatkan Motivasi Belajar dalam Pembelajaran Ilmu Pengetahuan Alam (IPA) Melalui Bacaan Populer. Seminar Nasional Biologi 2019 Inovasi Penelitian dan Pembelajaran Biologi III (IP2B III), Universitas Negeri Surabaya (UNESA). DOI: https://dx.doi.org/10.13140/RG.2.2.13087.71847

Setiawan, Adib Rifqi. (2019, May 07). Penerapan Pendekatan Saintifik untuk Melatih Literasi Saintifik dalam Domain Kompetensi pada Topik Gerak Lurus di Sekolah Menengah Pertama. Prosiding Seminar Nasional Fisika (SiNaFi) 2018: 7-13. URL: http://proceedings.upi.edu/index.php/sinafi/article/view/355 
Setiawan, Adib Rifqi. (2019, November 23). Analisis Keabsahan dan Keandalan Science Motivation Questionnaire II (SMQ II) Versi Bahasa Indonesia. Seminar Nasional Fisika V (SiNaFi 5.0), Universitas Pendidikan Indonesia (UPI). DOI: https://doi.org/10.31237/osf.io/6zeph

Setiawan, Adib Rifqi. (2019, November 23). Menyusun Instrumen Penilaian untuk Pembelajaran Topik Lingkungan Berorientasi Literasi Saintifik. Seminar Nasional Fisika $V$ (SiNaFi 5.0), Universitas Pendidikan Indonesia (UPI). DOI: https://dx.doi.org/10.35542/osf.io/sc6d2

Setiawan, Adib Rifqi. (2019, November 23). Profil Literasi Saintifik Berdasarkan Kecerdasan Majemuk dan Motivasi Belajar. Seminar Nasional Fisika V (SiNaFi 5.0), Universitas Pendidikan Indonesia (UPI). DOI: https://dx.doi.org/10.35542/osf.io/m7n95

Setiawan, Adib Rifqi. (2019, October 02). Efektivitas Pembelajaran Biologi Berorientasi Literasi Saintifik. Thabiea : Journal of Natural Science Teaching, 02 (02): 83-94. DOI: http://dx.doi.org/10.21043/thabiea.v2i2.5345

Setiawan, Adib Rifqi. (2019, October 05). Menyusun Instrumen Penilaian untuk Pembelajaran Ekologi Berorientasi Literasi Saintifik. Seminar Nasional \& Workshop Biologi, IPA, dan Pembelajarannya ke-4 (SnoWBel IV), Universitas Negeri Malang (UM). DOI: https://dx.doi.org/10.13140/RG.2.2.21931.39206

Setiawan, Adib Rifqi. (2019, October 14). Penyusunan Program Pembelajaran Biologi Berorientasi Literasi Saintifik. Seminar Nasional Sains \& Entrepreneurship VI (SNSE VI): 255-1-8. URL: http://conference.upgris.ac.id/index.php/snse/article/view/255

Setiawan, Adib Rifqi. (2019, October 8). Biografi Clara Ng Perempuan Penulis Asal Indonesia. Psy/ArXiv. DOI: https://doi.org/10.31234/osf.io/yk8sx

Setiawan, Adib Rifqi. (2019, September 30). Instrumen Penilaian untuk Pembelajaran Ekologi Berorientasi Literasi Saintifik. Assimilation: Indonesian Journal of Biology Education, 02(02): 42-46. DOI: https://dx.doi.org/10.17509/aijbe.v2i2.19250

Setiawan, Adib Rifqi. (2020, April 1). Sharifah Halimah Alaydrus. Thesis Commons. DOI: https://doi.org/10.31237/osf.io/fp79c

Setiawan, Adib Rifqi. (2020, April 1). Syarifah Halimah Alaydrus. Thesis Commons. DOI: https://doi.org/10.31237/osf.io/xbmcs

Setiawan, Adib Rifqi. (2020, April 13). Commodification of the Sexuality in Kim Kardashian's Instagram Posts. Thesis Commons. URL: https://thesiscommons.org/mf7nw/

Setiawan, Adib Rifqi. (2020, April 13). مبادئ اللغة العربية. Thesis Commons. DOI: https://doi.org/10.31237/osf.io/2gvjf

Setiawan, Adib Rifqi. (2020, April 14). Commodification of the Sexuality in Kim Kardashian's Instagram Posts. SocArXiv. DOI: https://doi.org/10.31235/osf.io/kd6au

Setiawan, Adib Rifqi. (2020, April 14). Jalāl al-Dīn 'Abd al-Roḥmān ibn Abī Bakr al-Suyūṭ̂̄. SocArXiv. DOI: https://doi.org/10.31235/osf.io/5zf9v

Setiawan, Adib Rifqi. (2020, April 18). Musyāfahah al-Qur'ān Melalui Media Elektronik. Thesis Commons. URL: https://thesiscommons.org/ntjp9/

Setiawan, Adib Rifqi. (2020, April 2). Desain Pembelajaran untuk Membimbing Siswa Sekolah Dasar dalam Memperoleh Literasi Saintifik. EdArXiv. DOI: https://doi.org/10.35542/osf.io/u59f8

Setiawan, Adib Rifqi. (2020, April 2). JUPE My Uncut Story. Open Science Framework (OSF). DOI: https://doi.org/10.31219/osf.io/qdxga

Setiawan, Adib Rifqi. (2020, April 2). What is the Best Way to Analyze Pre-Post Data?. EdArXiv. DOI: https://doi.org/10.35542/osf.io/h4e6q

Setiawan, Adib Rifqi. (2020, April 20). Menyusun Instrumen Penilaian untuk Pembelajaran Ekologi Berorientasi Literasi Saintifik. Prosiding Seminar Nasional dan Workshop 
Biologi-IPA dan Pembelajaran Ke-4 (SnoWBel IV): 241-9. ISBN : 978-602-470-1703 \& e-ISBN : 978-602-470-171-0.

Setiawan, Adib Rifqi. (2020, April 21). Lembar Kegiatan Literasi Saintifik untuk Pembelajaran Jarak Jauh Topik Penyakit Coronavirus 2019 (COVID-19). Edukatif: Jurnal Ilmu Pendidikan, 02(01): 28-37. DOI: https://doi.org/10.31004/edukatif.v2i1.80

Setiawan, Adib Rifqi. (2020, April 3). Sharifah Halimah Alaydrus : a female preachers for our time. SocArXiv. DOI: https://doi.org/10.31235/osf.io/zb8qe

Setiawan, Adib Rifqi. (2020, April 4). Grace Natalie Louisa. SocArXiv. DOI: https://doi.org/10.31235/osf.io/zwf6g

Setiawan, Adib Rifqi. (2020, April 4). Grace Natalie Louisa. Thesis Commons. DOI: https://doi.org/10.31237/osf.io/u3mxv

Setiawan, Adib Rifqi. (2020, April 5). The Arrogant One. Thesis Commons. DOI: https://doi.org/10.31237/osf.io/8nmku

Setiawan, Adib Rifqi. (2020, April 9). Islamic Education in Southeast Asia. EdArXiv. DOI: https://doi.org/10.35542/osf.io/dnjqv

Setiawan, Adib Rifqi. (2020, April 9). Islamic Education in Southeast Asia. Thesis Commons. DOI: https://doi.org/10.31237/osf.io/e794d

Setiawan, Adib Rifqi. (2020, February 18). Menyusun Instrumen Penilaian untuk Pembelajaran Topik Lingkungan Berorientasi Literasi Saintifik. Prosiding Seminar Nasional Fisika (SiNaFi) 2019: 15-21. URL:

http://proceedings.upi.edu/index.php/sinafi/article/view/563

Setiawan, Adib Rifqi. (2020, January 17). Penerapan Pendekatan Saintifik dalam Pembelajaran Biologi sebagai Upaya Melatih Literasi Saintifik. Prosiding Seminar Nasional Biologi 2019 Inovasi Penelitian dan Pembelajaran Biologi III (IP2B III): 140-145. URL: http://semnasbiologi.conference.unesa.ac.id/ocs/index.php/semnasbio/IP2BII I/paper/viewFile/6/19

Setiawan, Adib Rifqi. (2020, January 17). Penggunaan Mabadi ‘Asyroh dalam Pembelajaran Biologi untuk Meningkatkan Motivasi dan Hasil Belajar. Prosiding Seminar Nasional Biologi 2019 Inovasi Penelitian dan Pembelajaran Biologi III (IP2B III): 158164. URL: http://semnasbiologi.conference.unesa.ac.id/ocs/index.php/semnasbio/IP2BII $\mathrm{I} /$ paper/viewFile/11/21

Setiawan, Adib Rifqi. (2020, January 17). Upaya Meningkatkan Motivasi Belajar dalam Pembelajaran Ilmu Pengetahuan Alam (IPA) Melalui Bacaan Populer. Prosiding Seminar Nasional Biologi 2019 Inovasi Penelitian dan Pembelajaran Biologi III (IP2B III): 154-157. URL:

http://semnasbiologi.conference.unesa.ac.id/ocs/index.php/semnasbio/IP2BII I/paper/viewFile/5/51

Setiawan, Adib Rifqi. (2020, January 24). Pembelajaran Tematik Berorientasi Literasi Saintifik. Jurnal Basicedu: Journal of Elementary Education, 04(01): 71-80. URL: https://jbasic.org/index.php/basicedu/article/view/298

Setiawan, Adib Rifqi. (2020, March 01). Pendidikan Literasi Finansial Melalui Pembelajaran Fiqh Mu'āmalāt Berbasis Kitab Kuning. Ną̧hruna: Jurnal Pendidikan Islam, 03(01): 138-159. DOI: https://dx.doi.org/10.31538/nzh.v3i1.522

Setiawan, Adib Rifqi. (2020, May 12). Introducing the Indonesian Education System. Thesis Commons. DOI: https://doi.org/10.31237/osf.io/ygt5c

Setiawan, Adib Rifqi. (2020, May 6). Discovering the Meaning of Fadhilaturrahmi's Work. Thesis Commons. DOI: https://doi.org/10.31237/osf.io/krf7z

Setiawan, Adib Rifqi. (2020, May 6). Menyibak Makna Karya Fadhilaturrahmi. LIS Scholarship Archive. DOI: https://doi.org/10.31229/osf.io/65y4z 
Setiawan, Adib Rifqi; \& Ilmiyah, Surotul. (2020, April 13). Kecerdasan Majemuk Berdasarkan Neurosains. EdArXiv. DOI: https://doi.org/10.35542/osf.io/rj2fe

Setiawan, Adib Rifqi; \& Ilmiyah, Surotul. (2020, April 13). Multiple Intelligences Based on Neuroscience. Thesis Commons. DOI: https://doi.org/10.31237/osf.io/e9fyu

Setiawan, Adib Rifqi; \& Ilmiyah, Surotul. (2020, April 7). Lembar Kegiatan Siswa untuk Pembelajaran Jarak Jauh Berdasarkan Literasi Saintifik pada Topik Penyakit Coronavirus 2019 (COVID-19). EdArXiv. DOI: https://doi.org/10.35542/osf.io/h4632

Setiawan, Adib Rifqi; Mufassaroh, Arii Zulfi. (2019, June 28). Menyusun Soal Literasi Saintifik untuk Pembelajaran Biologi Topik Plantae dan Animalia. BIOSFER: Jurnal Biologi dan Pendidikan Biologi, 04(01): 33-40. URL: http://dx.doi.org/10.23969/biosfer.v4i1.1484

Setiawan, Adib Rifqi; Puspaningrum, Mita; Umam, Khoirul. (2019, December 06). Pembelajaran Fiqh Mu'āmalāt Berorientasi Literasi Finansial. Tarbany: Indonesian Journal of Islamic Education, 06(02): 187-102. URL: https://ejournal.upi.edu/index.php/tarbawy/article/view/20887

Setiawan, Adib Rifqi; Saputri, Wahyu EKa. (2020, December 10). Pembelajaran Literasi Saintifik untuk Pendidikan Dasar. Media Penelitian Pendidikan : Jurnal Penelitian dalam Bidang Pendidikan dan Pengajaran, 14(02). DOI: https://doi.org/10.26877/mpp.v14i2.5794

Setiawan, Adib Rifqi; Saputri, Wahyu EKa. (2020, June 13). Science Motivation Questionnaire II (SMQ II) Versi Bahasa Indonesia. PsyArXiv. DOI: https://doi.org/10.31234/osf.io/tac2k

Setiawan, Adib Rifqi; Utari, Setiya; Nugraha, Muhamad Gina. (2016, December 17). Mengonstruksi Rancangan Soal Domain Kompetensi Literasi Saintifik Siswa SMP Kelas VIII pada Topik Gerak Lurus. Seminar Nasional Fisika ke-2 (SiNaFi II), Universitas Pendidikan Indonesia (UPI). DOI: https://dx.doi.org/10.13140/RG.2.2.31856.10246/1

Setiawan, Adib Rifqi; Utari, Setiya; Nugraha, Muhamad Gina. (2017, September 22). Mengonstruksi Rancangan Soal Domain Kompetensi Literasi Saintifik Siswa SMP Kelas VIII pada Topik Gerak Lurus. Wahana Pendidikan Fisika, 02(02): 44 48. URL: https://ejournal.upi.edu/index.php/WPF/article/view/8277/0

Siayah, Syarofis; \& Setiawan, Adib Rifqi. (2020, April 13). A Brief Explanation of Science Education. EdArXiv. DOI: https://doi.org/10.35542/osf.io/2evn3

Siayah, Syarofis; \& Setiawan, Adib Rifqi. (2020, April 13). A Brief Explanation of Science Education. Thesis Commons. DOI: https://doi.org/10.31237/osf.io/wkvsn

Velasufah, Whasfi; \& Setiawan, Adib Rifqi. (2020, April 13). Nilai Pesantren Sebagai Dasar Pendidikan Karakter. Thesis Commons. DOI: https://doi.org/10.31237/osf.io/hq6kz

Amatullah; \& Setiawan, Adib Rifqi. (2017, October 10). Nadirsyah Hosen: berkarya sebagai diaspora. Majalab SANTRI, 7: 56-59. URL: https://issuu.com/majalahsantri/docs/santri_edisi_7/58

Feldman, DarHalevy; \& Setiawan, Adib Rifqi. (2020, April 24). Education in Israel. Thesis Commons. DOI: https://doi.org/10.31237/osf.io/62shg

Ilmiyah, Surotul; \& Setiawan, Adib Rifqi. (2020, April 7). Students' Worksheet for Distance Learning Based on Scientific Literacy in the Topic Coronavirus Disease 2019 (COVID-19). Thesis Commons. DOI: https://doi.org/10.31237/osf.io/fpg4j

Ilmiyah, Surotul; \& Setiawan, Adib Rifqi. (2020, April 7). Students' Worksheet for Distance Learning Based on Scientific Literacy in the Topic Coronavirus Disease 2019 (COVID-19). EdArXiv. DOI: https://doi.org/10.35542/osf.io/wyz5v 
Setiawan, A. R. (2020, May 7). Discovering the Fundamental Problem of Four Methods to Analyze Data. Thesis Commons. DOI: https://doi.org/10.31237/osf.io/h953y

Setiawan, Adib Rifqi. (2015, November 03). Dibalik Nama Besar Albert Einstein: Dari Politik, Asmara, hingga Matematika. fisikanet.lipi.go.id. URL:

http://www.fisikanet.lipi.go.id/utama.cgi?artikel\&1446556354\&2

Setiawan, Adib Rifqi. (2015, November 07). Dibalik Sampul Buku A Brief History of Time, agar pengetahuan tak hanya dinikmati ilmuwan. fisikanet.lipi.go.id. URL: http://www.fisikanet.lipi.go.id/utama.cgi?artikel\&1446855103\&2

Setiawan, Adib Rifqi. (2015, November 10). Kehidupan Asmara Hawking: raga lumpuh, jiwa masih bisa tersentuh. fisikanet.lipi.go.id. URL: http://www.fisikanet.lipi.go.id/utama.cgi?artikel\&1447145876\&2

Setiawan, Adib Rifqi. (2015, October 10). 10 Kejutan Subatomik. fisikanet.lipi.go.id. URL: http://www.fisikanet.lipi.go.id/utama.cgi?artikel\&1444577286\&3

Setiawan, Adib Rifqi. (2015, October 31). Kurir Mikroskopis Alam Semesta bukan debu biasa. fisikanet.lipi.go.id. URL: http://www.fisikanet.lipi.go.id/utama.cgi?artikel\&1446304060\&2

Setiawan, Adib Rifqi. (2017, February 24). Penerapan Pendekatan Saintifik untuk Melatibkan Literasi Saintifik dalam Domain Kompetensi pada Topik Gerak Lurus di Sekolah Menengah Pertama. Undergraduate Thesis. Bandung: Universitas Pendidikan Indonesia. URL: http:// repository.upi.edu/29074/

Setiawan, Adib Rifqi. (2017, June 02). Aisha. qureta.com. URL: https://www.qureta.com/next/post/aisha-humaira

Setiawan, Adib Rifqi. (2017, June 03). Dari Yuli Hingga Julia. qureta.com. URL: https://www.qureta.com/next/post/dari-yuli-hingga-julia-2

Setiawan, Adib Rifqi. (2018, April 10). Busana: pemantas raga, pelaras jiwa. Majalab SANTRI, 8: 26-27. URL: https://issuu.com/majalahsantri/docs/majalah_santri_8/28

Setiawan, Adib Rifqi. (2018, April 10). Eny Rochmawati Octaviani: memberikan hiburan, menyuntikkan harapan. Majalah SANTRI, 8: 15-18. URL: https://issuu.com/majalahsantri/docs/majalah_santri_8/17

Setiawan, Adib Rifqi. (2018, April 10). Rosa Amalia Iqony: paduan yakin diri dan rendah hati. Majalah SANTRI, 8: 46. URL: https://issuu.com/majalahsantri/docs/majalah_santri_8/48

Setiawan, Adib Rifqi. (2018, December 18). Irma Rahma Suwarma. qureta.com. URL: https://www.qureta.com/next/post/irma-rahma-suwarma

Setiawan, Adib Rifqi. (2018, July 03). Tangis Daniela Hantuchová. qureta.com. URL: https://www.qureta.com/next/post/tangis-daniela-hantuchova

Setiawan, Adib Rifqi. (2018, July 16). Rustriningsih, Srikandi Tersisih. qureta.com. URL: https://www.qureta.com/next/post/rustriningsih-srikandi-tersisih

Setiawan, Adib Rifqi. (2018, June 27). Ice. qureta.com. URL: https://www.qureta.com/next/post/ice

Setiawan, Adib Rifqi. (2018, June 28). Dewi Perssik. qureta.com. URL: https://www.qureta.com/next/post/dewi-perssik

Setiawan, Adib Rifqi. (2018, March 06). Breast Capital. qureta.com. URL: https://www.qureta.com/next/post/breast-capital

Setiawan, Adib Rifqi. (2018, March 06). Menyoal Vokal Duo Serigala. qureta.com. URL: https://www.qureta.com/next/post/menyoal-vokal-duo-serigala

Setiawan, Adib Rifqi. (2018, March 07). Mengenal Oza Kioza. qureta.com. URL: https://www.qureta.com/next/post/mengenal-oza-kioza

Setiawan, Adib Rifqi. (2018, March 09). Asal Usul Nama Via Vallen. qureta.com. URL: https://www.qureta.com/next/post/asal-usul-nama-via-vallen 
Setiawan, Adib Rifqi. (2018, March 09). Kepedulian Airin Rachmi Diany pada Pendidikan. qureta.com. URL: https://www.qureta.com/next/post/kepedulian-airin-rachmidiany-pada-pendidikan

Setiawan, Adib Rifqi. (2018, March 09). Ketika YoonA Menyaksikan Real Madrid Menghempaskan PSG. qureta.com. URL: https://www.qureta.com/next/post/ketika-yoona-menyaksikan-real-madridmenghempaskan-psg

Setiawan, Adib Rifqi. (2018, March 09). Laila Fariha Zein (a.k.a. Uus atau Febi). qureta.com. URL: https://www.qureta.com/next/post/laila-fariha-zein-febi

Setiawan, Adib Rifqi. (2018, March 09). Pantat Perekat Umat. qureta.com. URL: https://www.qureta.com/next/post/pantat-perekat-umat

Setiawan, Adib Rifqi. (2018, March 09). Sisi Religi Grace Natalie. qureta.com. URL: https://www.qureta.com/next/post/sisi-religi-grace-natalie

Setiawan, Adib Rifqi. (2018, March 10). Venice Min. qureta.com. URL: https://www.qureta.com/next/post/venice-min

Setiawan, Adib Rifqi. (2018, March 11). Kisah Kasih Ayah di Balik Mata Najwa. qureta.com. URL: https://www.qureta.com/next/post/kisah-kasih-ayah-di-balik-mata-najwa

Setiawan, Adib Rifqi. (2018, March 11). Rosa Amalia Iqony. qureta.com. URL: https://www.qureta.com/next/post/rosa-amalia-iqony

Setiawan, Adib Rifqi. (2018, March 12). Clara Ng. qureta.com. URL: https://www.qureta.com/next/post/clara-ng

Setiawan, Adib Rifqi. (2018, March 14). Meniti Ilmuwati. qureta.com. URL: https://www.qureta.com/next/post/meniti-ilmuwati

Setiawan, Adib Rifqi. (2018, March 14). Surely You're Joking, Mrs. Ilmy!. qureta.com. URL: https://www.qureta.com/next/post/surely-you-re-joking-mrs-ilmy

Setiawan, Adib Rifqi. (2018, March 15). Eny R. Octaviani. qureta.com. URL: https://www.qureta.com/next/post/eny-r-octaviani

Setiawan, Adib Rifqi. (2018, March 17). Maryam Musfiroh: An Educator for Our Time. qureta.com. URL: https://www.qureta.com/next/post/maryam-musfiroh-aneducator-for-our-time

Setiawan, Adib Rifqi. (2018, March 19). Airin Rachmi Diany, Lilin Penerang Masyarakat Urban. qureta.com. URL: https://www.qureta.com/next/post/airin-rachmi-diany-lilinpenerang-masyarakat-urban

Setiawan, Adib Rifqi. (2018, March 19). Guru yang Menyapih: Catatan Perjalanan Pribadi Nong Darol Mahmada. qureta.com. URL: https://www.qureta.com/next/post/guruyang-menyapih-catatan-perjalanan-pribadi-nong-darol-mahmada

Setiawan, Adib Rifqi. (2018, March 19). Kamu dalam Aku: A Brief Story of Park Bom. qureta.com. URL: https://www.qureta.com/next/post/kamu-dalam-aku-a-brief-storyof-park-bom

Setiawan, Adib Rifqi. (2018, March 21). Bidadari di Kesunyian itu Bernama Maria Sharapova. qureta.com. URL: https://www.qureta.com/next/post/bidadari-di-kesunyianitu-bernama-maria-sharapova

Setiawan, Adib Rifqi. (2018, March 25). Novi Kaka: Sahabat, Panutan, Pembimbing. qureta.com. URL: https://www.qureta.com/next/post/novi-kaka-sahabat-panutanpembimbing

Setiawan, Adib Rifqi. (2018, May 24). Fakhrun. qureta.com. URL: https://www.qureta.com/next/post/fakhrun

Setiawan, Adib Rifqi. (2018, November 24). Penerapan Pendekatan Saintifik untuk Melatih Literasi Saintifik dalam Domain Kompetensi pada Topik Gerak Lurus di Sekolah Menengah Pertama. Seminar Nasional Fisika ke-4 (SiNaFi IV), 
Universitas Pendidikan Indonesia (UPI). DOI:

https://dx.doi.org/10.13140/RG.2.2.23154.04809

Setiawan, Adib Rifqi. (2018, October 05). Karen Armstrong. qureta.com. URL:

https://www.qureta.com/next/post/karen-armstrong

Setiawan, Adib Rifqi. (2018, September 17). Lola Zieta Azelien. qureta.com. URL:

https://www.qureta.com/next/post/lola-zieta-azelien

Setiawan, Adib Rifqi. (2019, August 21). Penyusunan Program Pembelajaran Biologi Berorientasi Literasi Saintifik. Seminar Nasional Sains \& Entrepreneurship VI (SNSE VI), Universitas PGRI Semarang (UPGRIS). DOI:

https://dx.doi.org/10.13140/RG.2.2.13716.86400

Setiawan, Adib Rifqi. (2019, December 20). Literasi Saintifik Berdasarkan Kecerdasan Majemuk dan Motivasi Belajar. Media Penelitian Pendidikan: Jurnal Penelitian dalam Bidang Pendidikan dan Pengajaran, 13(02): 126-137. DOI: http://dx.doi.org/10.26877/mpp.v13i2.4913

Setiawan, Adib Rifqi. (2019, December 23). Contoh Langkah Pembelajaran Berorientasi Literasi Saintifik. santrimilenial.net. URL: https://santrimilenial.net/contoh-langkahpembelajaran-berorientasi-literasi-saintifik/

Setiawan, Adib Rifqi. (2019, December 30). Instrumen Penilaian Pembelajaran Fiqh Mu'āmalāt Berorientasi Literasi Finansial. Eklektik: Jurnal Pendidikan Ekonomi dan Kewirausahaan, 02(02): 258-272. DOI: http://dx.doi.org/10.24014/ekl.v2i2.8117

Setiawan, Adib Rifqi. (2019, June 14). Deasy Noviyanti, Perempuan Berbadan Defisit Lemak. qureta.com. URL: https://www.qureta.com/next/post/deasy-noviyantiperempuan-berbadan-defisit-lemak

Setiawan, Adib Rifqi. (2019, June 26). Peningkatan Literasi Saintifik melalui Pembelajaran Biologi Menggunakan Pendekatan Saintifik. Journal of Biology Education, 02(01): 223-235.

URL: http://journal.stainkudus.ac.id/index.php/jbe/article/view/5278

Setiawan, Adib Rifqi. (2019, March 23). Penerapan Pendekatan Saintifik dalam Pembelajaran Biologi sebagai Upaya Melatih Literasi Saintifik Siswa Sekolah Menengah.

Seminar Nasional Biologi 2019 Inovasi Penelitian dan Pembelajaran Biologi III (IP2B III), Universitas Negeri Surabaya (UNESA). DOI:

https://dx.doi.org/10.13140/RG.2.2.19798.60484

Setiawan, Adib Rifqi. (2019, March 23). Penggunaan Naḍom Mabàdī'Asyroh dalam Pembelajaran Biologi untuk Meningkatkan Motivasi dan Hasil Belajar. Seminar Nasional Biologi 2019 Inovasi Penelitian dan Pembelajaran Biologi III (IP2B III), Universitas Negeri Surabaya (UNESA). DOI: https://dx.doi.org/10.13140/RG.2.2.33220.37763

Setiawan, Adib Rifqi. (2019, March 23). Upaya Meningkatkan Motivasi Belajar dalam Pembelajaran Ilmu Pengetahuan Alam (IPA) Melalui Bacaan Populer. Seminar Nasional Biologi 2019 Inovasi Penelitian dan Pembelajaran Biologi III (IP2B III), Universitas Negeri Surabaya (UNESA). DOI: https://dx.doi.org/10.13140/RG.2.2.13087.71847

Setiawan, Adib Rifqi. (2019, May 07). Penerapan Pendekatan Saintifik untuk Melatih Literasi Saintifik dalam Domain Kompetensi pada Topik Gerak Lurus di Sekolah Menengah Pertama. Prosiding Seminar Nasional Fisika (SiNaFi) 2018: 7-13. URL: http://proceedings.upi.edu/index.php/sinafi/article/view/355

Setiawan, Adib Rifqi. (2019, November 23). Analisis Keabsahan dan Keandalan Science Motivation Questionnaire II (SMQ II) Versi Bahasa Indonesia. Seminar Nasional Fisika V (SiNaFi 5.0), Universitas Pendidikan Indonesia (UPI). DOI: https://doi.org/10.31237/osf.io/6zeph

Setiawan, Adib Rifqi. (2019, November 23). Menyusun Instrumen Penilaian untuk Pembelajaran Topik Lingkungan Berorientasi Literasi Saintifik. Seminar Nasional Fisika $V$ 
(SiNaFi 5.0), Universitas Pendidikan Indonesia (UPI). DOI:

https://dx.doi.org/10.35542/osf.io/sc6d2

Setiawan, Adib Rifqi. (2019, November 23). Profil Literasi Saintifik Berdasarkan Kecerdasan

Majemuk dan Motivasi Belajar. Seminar Nasional Fisika V (SiNaFi 5.0),

Universitas Pendidikan Indonesia (UPI). DOI:

https://dx.doi.org/10.35542/osf.io/m7n95

Setiawan, Adib Rifqi. (2019, October 02). Efektivitas Pembelajaran Biologi Berorientasi Literasi

Saintifik. Thabiea : Journal of Natural Science Teaching, 02 (02): 83-94. DOI:

http://dx.doi.org/10.21043/thabiea.v2i2.5345

Setiawan, Adib Rifqi. (2019, October 05). Menyusun Instrumen Penilaian untuk Pembelajaran Ekologi Berorientasi Literasi Saintifik. Seminar Nasional \& Workshop Biologi, IPA, dan Pembelajarannya ke-4 (SnoWBel IV), Universitas Negeri Malang (UM). DOI: https://dx.doi.org/10.13140/RG.2.2.21931.39206

Setiawan, Adib Rifqi. (2019, October 14). Penyusunan Program Pembelajaran Biologi Berorientasi Literasi Saintifik. Seminar Nasional Sains \& Entrepreneurship VI (SNSE VI): 255-1-8. URL:

http://conference.upgris.ac.id/index.php/snse/article/view/255

Setiawan, Adib Rifqi. (2019, October 8). Biografi Clara Ng Perempuan Penulis Asal Indonesia. PsyArXiv. DOI: https://doi.org/10.31234/osf.io/yk8sx

Setiawan, Adib Rifqi. (2019, September 30). Instrumen Penilaian untuk Pembelajaran Ekologi Berorientasi Literasi Saintifik. Assimilation: Indonesian Journal of Biology Education, 02(02): 42-46. DOI: https://dx.doi.org/10.17509/aijbe.v2i2.19250

Setiawan, Adib Rifqi. (2020, April 1). Sharifah Halimah Alaydrus. Thesis Commons. DOI: https://doi.org/10.31237/osf.io/fp79c

Setiawan, Adib Rifqi. (2020, April 1). Syarifah Halimah Alaydrus. Thesis Commons. DOI: https://doi.org/10.31237/osf.io/xbmcs

Setiawan, Adib Rifqi. (2020, April 13). Commodification of the Sexuality in Kim Kardashian's Instagram Posts. Thesis Commons. URL: https://thesiscommons.org/mf7nw/

Setiawan, Adib Rifqi. (2020, April 13). مبادئ اللغة العربية. Thesis Commons. DOI: https://doi.org/10.31237/osf.io/2gvjf

Setiawan, Adib Rifqi. (2020, April 14). Commodification of the Sexuality in Kim Kardashian's Instagram Posts. SocArXiv. DOI: https://doi.org/10.31235/osf.io/kd6au

Setiawan, Adib Rifqi. (2020, April 14). Jalāl al-Dīn 'Abd al-Roḥmān ibn Abī Bakr al-Suyūṭ̂̄. SocArXiv. DOI: https://doi.org/10.31235/osf.io/5zf9v

Setiawan, Adib Rifqi. (2020, April 18). Musyāfahah al-Qur'ān Melalui Media Elektronik. Thesis Commons. URL: https://thesiscommons.org/ntjp9/

Setiawan, Adib Rifqi. (2020, April 2). Desain Pembelajaran untuk Membimbing Siswa Sekolah Dasar dalam Memperoleh Literasi Saintifik. EdArXiv. DOI: https://doi.org/10.35542/osf.io/u59f8

Setiawan, Adib Rifqi. (2020, April 2). JUPE My Uncut Story. Open Science Framework (OSF). DOI: https://doi.org/10.31219/osf.io/qdxga

Setiawan, Adib Rifqi. (2020, April 2). What is the Best Way to Analyze Pre-Post Data?. EdArXiv. DOI: https://doi.org/10.35542/osf.io/h4e6q

Setiawan, Adib Rifqi. (2020, April 20). Menyusun Instrumen Penilaian untuk Pembelajaran Ekologi Berorientasi Literasi Saintifik. Prosiding Seminar Nasional dan Workshop Biologi-IPA dan Pembelajaran Ke-4 (SnoWBel IV): 241-9. ISBN : 978-602-470-1703 \& e-ISBN : 978-602-470-171-0.

Setiawan, Adib Rifqi. (2020, April 21). Lembar Kegiatan Literasi Saintifik untuk Pembelajaran Jarak Jauh Topik Penyakit Coronavirus 2019 (COVID-19). Edukatif: Jurnal Ilmu Pendidikan, 02(01): 28-37. DOI: https://doi.org/10.31004/edukatif.v2i1.80 
Setiawan, Adib Rifqi. (2020, April 3). Sharifah Halimah Alaydrus : a female preachers for our time. SocArXiv. DOI: https://doi.org/10.31235/osf.io/zb8qe

Setiawan, Adib Rifqi. (2020, April 4). Grace Natalie Louisa. SocArXiv. DOI: https://doi.org/10.31235/osf.io/zwf6g

Setiawan, Adib Rifqi. (2020, April 4). Grace Natalie Louisa. Thesis Commons. DOI: https://doi.org/10.31237/osf.io/u3mxv

Setiawan, Adib Rifqi. (2020, April 5). The Arrogant One. Thesis Commons. DOI: https://doi.org/10.31237/osf.io/8nmku

Setiawan, Adib Rifqi. (2020, April 9). Islamic Education in Southeast Asia. EdArXiv. DOI: https://doi.org/10.35542/osf.io/dnjqv

Setiawan, Adib Rifqi. (2020, April 9). Islamic Education in Southeast Asia. Thesis Commons. DOI: https://doi.org/10.31237/osf.io/e794d

Setiawan, Adib Rifqi. (2020, February 18). Menyusun Instrumen Penilaian untuk Pembelajaran Topik Lingkungan Berorientasi Literasi Saintifik. Prosiding Seminar Nasional Fisika (SiNaFi) 2019: 15-21. URL:

http://proceedings.upi.edu/index.php/sinafi/article/view/563

Setiawan, Adib Rifqi. (2020, January 17). Penerapan Pendekatan Saintifik dalam Pembelajaran Biologi sebagai Upaya Melatih Literasi Saintifik. Prosiding Seminar Nasional Biologi 2019 Inovasi Penelitian dan Pembelajaran Biologi III (IP2B III): 140-145. URL: http://semnasbiologi.conference.unesa.ac.id/ocs/index.php/semnasbio/IP2BII I/paper/viewFile/6/19

Setiawan, Adib Rifqi. (2020, January 17). Penggunaan Mabadi 'Asyroh dalam Pembelajaran Biologi untuk Meningkatkan Motivasi dan Hasil Belajar. Prosiding Seminar Nasional Biologi 2019 Inovasi Penelitian dan Pembelajaran Biologi III (IP2B III): 158164. URL:

http://semnasbiologi.conference.unesa.ac.id/ocs/index.php/semnasbio/IP2BII $\mathrm{I} /$ paper/viewFile/11/21

Setiawan, Adib Rifqi. (2020, January 17). Upaya Meningkatkan Motivasi Belajar dalam Pembelajaran Ilmu Pengetahuan Alam (IPA) Melalui Bacaan Populer. Prosiding Seminar Nasional Biologi 2019 Inovasi Penelitian dan Pembelajaran Biologi III (IP2B III): 154-157. URL: http://semnasbiologi.conference.unesa.ac.id/ocs/index.php/semnasbio/IP2BII I/paper/viewFile/5/51

Setiawan, Adib Rifqi. (2020, January 24). Pembelajaran Tematik Berorientasi Literasi Saintifik. Jurnal Basicedu: Journal of Elementary Education, 04(01): 71-80. URL: https://jbasic.org/index.php/basicedu/article/view/298

Setiawan, Adib Rifqi. (2020, March 01). Pendidikan Literasi Finansial Melalui Pembelajaran Fiqh Mu'āmalāt Berbasis Kitab Kuning. Ną̧,runa: Jurnal Pendidikan Islam, 03(01): 138-159. DOI: https://dx.doi.org/10.31538/nzh.v3i1.522

Setiawan, Adib Rifqi. (2020, May 12). Introducing the Indonesian Education System. Thesis Commons. DOI: https://doi.org/10.31237/osf.io/ygt5c

Setiawan, Adib Rifqi. (2020, May 6). Discovering the Meaning of Fadhilaturrahmi's Work. Thesis Commons. DOI: https://doi.org/10.31237/osf.io/krf7z

Setiawan, Adib Rifqi. (2020, May 6). Menyibak Makna Karya Fadhilaturrahmi. LIS Scholarship Archive. DOI: https://doi.org/10.31229/osf.io/65y4z

Setiawan, Adib Rifqi; \& Ilmiyah, Surotul. (2020, April 13). Kecerdasan Majemuk Berdasarkan Neurosains. EdArXiv. DOI: https://doi.org/10.35542/osf.io/rj2fe

Setiawan, Adib Rifqi; \& Ilmiyah, Surotul. (2020, April 13). Multiple Intelligences Based on Neuroscience. Thesis Commons. DOI: https://doi.org/10.31237/osf.io/e9fyu

Setiawan, Adib Rifqi; \& Ilmiyah, Surotul. (2020, April 7). Lembar Kegiatan Siswa untuk Pembelajaran Jarak Jauh Berdasarkan Literasi Saintifik pada Topik Penyakit 
Coronavirus 2019 (COVID-19). EdArXiv. DOI:

https://doi.org/10.35542/osf.io/h4632

Setiawan, Adib Rifqi; Mufassaroh, Arij Zulfi. (2019, June 28). Menyusun Soal Literasi Saintifik untuk Pembelajaran Biologi Topik Plantae dan Animalia. BIOSFER: Jurnal Biologi dan Pendidikan Biologi, 04(01): 33-40. URL: http://dx.doi.org/10.23969/biosfer.v4i1.1484

Setiawan, Adib Rifqi; Puspaningrum, Mita; Umam, Khoirul. (2019, December 06). Pembelajaran Fiqh Mu'āmalāt Berorientasi Literasi Finansial. Tarbany: Indonesian Journal of Islamic Education, 06(02): 187-102. URL: https://ejournal.upi.edu/index.php/tarbawy/article/view/20887

Setiawan, Adib Rifqi; Saputri, Wahyu EKa. (2020, December 10). Pembelajaran Literasi Saintifik untuk Pendidikan Dasar. Media Penelitian Pendidikan : Jumal Penelitian dalam Bidang Pendidikan dan Pengajaran, 14(02). DOI: https://doi.org/10.26877/mpp.v14i2.5794

Setiawan, Adib Rifqi; Saputri, Wahyu EKa. (2020, June 13). Science Motivation Questionnaire II (SMQ II) Versi Bahasa Indonesia. Psy ArXiv. DOI: https://doi.org/10.31234/osf.io/tac2k

Setiawan, Adib Rifqi; Utari, Setiya; Nugraha, Muhamad Gina. (2016, December 17). Mengonstruksi Rancangan Soal Domain Kompetensi Literasi Saintifik Siswa SMP Kelas VIII pada Topik Gerak Lurus. Seminar Nasional Fisika ke-2 (SiNaFi II), Universitas Pendidikan Indonesia (UPI). DOI: https://dx.doi.org/10.13140/RG.2.2.31856.10246/1

Setiawan, Adib Rifqi; Utari, Setiya; Nugraha, Muhamad Gina. (2017, September 22). Mengonstruksi Rancangan Soal Domain Kompetensi Literasi Saintifik Siswa SMP Kelas VIII pada Topik Gerak Lurus. Wahana Pendidikan Fisika, 02(02): 44 48. URL: https:// ejournal.upi.edu/index.php/WPF/article/view/8277/0

Siayah, Syarofis; \& Setiawan, Adib Rifqi. (2020, April 13). A Brief Explanation of Science Education. EdArXiv. DOI: https://doi.org/10.35542/osf.io/2evn3

Siayah, Syarofis; \& Setiawan, Adib Rifqi. (2020, April 13). A Brief Explanation of Science Education. Thesis Commons. DOI: https://doi.org/10.31237/osf.io/wkvsn

Velasufah, Whasfi; \& Setiawan, Adib Rifqi. (2020, April 13). Nilai Pesantren Sebagai Dasar Pendidikan Karakter. Thesis Commons. DOI: https://doi.org/10.31237/osf.io/hq6kz

Amatullah; \& Setiawan, Adib Rifqi. (2017, October 10). Nadirsyah Hosen: berkarya sebagai diaspora. Majalah SANTRI, 7: 56-59. URL: https://issuu.com/majalahsantri/docs/santri_edisi_7/58

Feldman, DarHalevy; \& Setiawan, Adib Rifqi. (2020, April 24). Education in Israel. Thesis Commons. DOI: https://doi.org/10.31237/osf.io/62shg

Ilmiyah, Surotul; \& Setiawan, Adib Rifqi. (2020, April 7). Students' Worksheet for Distance Learning Based on Scientific Literacy in the Topic Coronavirus Disease 2019 (COVID-19). Thesis Commons. DOI: https://doi.org/10.31237/osf.io/fpg4j

Ilmiyah, Surotul; \& Setiawan, Adib Rifqi. (2020, April 7). Students' Worksheet for Distance Learning Based on Scientific Literacy in the Topic Coronavirus Disease 2019 (COVID-19). EdArXiv. DOI: https://doi.org/10.35542/osf.io/wyz5v

Setiawan, A. R. (2020, May 7). Discovering the Fundamental Problem of Four Methods to Analyze Data. Thesis Commons. DOI: https://doi.org/10.31237/osf.io/h953y

Setiawan, Adib Rifqi. (2015, November 03). Dibalik Nama Besar Albert Einstein: Dari Politik, Asmara, hingga Matematika. fisikanet.lipi.go.id. URL:

http://www.fisikanet.lipi.go.id/utama.cgi?artikel\&1446556354\&2 
Setiawan, Adib Rifqi. (2015, November 07). Dibalik Sampul Buku A Brief History of Time, agar pengetahuan tak hanya dinikmati ilmuwan. fisikanet.lipi.go.id. URL: http://www.fisikanet.lipi.go.id/utama.cgi?artikel\&1446855103\&2

Setiawan, Adib Rifqi. (2015, November 10). Kehidupan Asmara Hawking: raga lumpuh, jiwa masih bisa tersentuh. fisikanet.lipi.go.id. URL: http://www.fisikanet.lipi.go.id/utama.cgi?artikel\&1447145876\&2

Setiawan, Adib Rifqi. (2015, October 10). 10 Kejutan Subatomik. fisikanet.lipi.go.id. URL: http:/ /www.fisikanet.lipi.go.id/utama.cgi?artikel\&1444577286\&3

Setiawan, Adib Rifqi. (2015, October 31). Kurir Mikroskopis Alam Semesta bukan debu biasa. fisikanet.lipi.go.id. URL: http://www.fisikanet.lipi.go.id/utama.cgi?artikel\&1446304060\&2

Setiawan, Adib Rifqi. (2017, February 24). Penerapan Pendekatan Saintifik untuk Melatibkan Literasi Saintifik dalam Domain Kompetensi pada Topik Gerak Lurus di Sekolah Menengah Pertama. Undergraduate Thesis. Bandung: Universitas Pendidikan Indonesia. URL: http:// repository.upi.edu/29074/

Setiawan, Adib Rifqi. (2017, June 02). Aisha. qureta.com. URL: https://www.qureta.com/next/post/aisha-humaira

Setiawan, Adib Rifqi. (2017, June 03). Dari Yuli Hingga Julia. qureta.com. URL: https://www.qureta.com/next/post/dari-yuli-hingga-julia-2

Setiawan, Adib Rifqi. (2018, April 10). Busana: pemantas raga, pelaras jiwa. Majalah SANTRI, 8: 26-27. URL: https://issuu.com/majalahsantri/docs/majalah_santri_8/28

Setiawan, Adib Rifqi. (2018, April 10). Eny Rochmawati Octaviani: memberikan hiburan, menyuntikkan harapan. Majalah SANTRI, 8: 15-18. URL: https://issuu.com/majalahsantri/docs/majalah_santri_8/17

Setiawan, Adib Rifqi. (2018, April 10). Rosa Amalia Iqony: paduan yakin diri dan rendah hati. Majalah SANTRI, 8: 46. URL: https://issuu.com/majalahsantri/docs/majalah_santri_8/48

Setiawan, Adib Rifqi. (2018, December 18). Irma Rahma Suwarma. qureta.com. URL: https://www.qureta.com/next/post/irma-rahma-suwarma

Setiawan, Adib Rifqi. (2018, July 03). Tangis Daniela Hantuchová. qureta.com. URL: https://www.qureta.com/next/post/tangis-daniela-hantuchova

Setiawan, Adib Rifqi. (2018, July 16). Rustriningsih, Srikandi Tersisih. qureta.com. URL: https://www.qureta.com/next/post/rustriningsih-srikandi-tersisih

Setiawan, Adib Rifqi. (2018, June 27). Ice. qureta.com. URL: https://www.qureta.com/next/post/ice

Setiawan, Adib Rifqi. (2018, June 28). Dewi Perssik. qureta.com. URL: https://www.qureta.com/next/post/dewi-perssik

Setiawan, Adib Rifqi. (2018, March 06). Breast Capital. qureta.com. URL: https://www.qureta.com/next/post/breast-capital

Setiawan, Adib Rifqi. (2018, March 06). Menyoal Vokal Duo Serigala. qureta.com. URL: https://www.qureta.com/next/post/menyoal-vokal-duo-serigala

Setiawan, Adib Rifqi. (2018, March 07). Mengenal Oza Kioza. qureta.com. URL: https://www.qureta.com/next/post/mengenal-oza-kioza

Setiawan, Adib Rifqi. (2018, March 09). Asal Usul Nama Via Vallen. qureta.com. URL: https://www.qureta.com/next/post/asal-usul-nama-via-vallen

Setiawan, Adib Rifqi. (2018, March 09). Kepedulian Airin Rachmi Diany pada Pendidikan. qureta.com. URL: https://www.qureta.com/next/post/kepedulian-airin-rachmidiany-pada-pendidikan

Setiawan, Adib Rifqi. (2018, March 09). Ketika YoonA Menyaksikan Real Madrid Menghempaskan PSG. qureta.com. URL: 
https://www.qureta.com/next/post/ketika-yoona-menyaksikan-real-madridmenghempaskan-psg

Setiawan, Adib Rifqi. (2018, March 09). Laila Fariha Zein (a.k.a. Uus atau Febi). qureta.com. URL: https://www.qureta.com/next/post/laila-fariha-zein-febi

Setiawan, Adib Rifqi. (2018, March 09). Pantat Perekat Umat. qureta.com. URL: https://www.qureta.com/next/post/pantat-perekat-umat

Setiawan, Adib Rifqi. (2018, March 09). Sisi Religi Grace Natalie. qureta.com. URL: https://www.qureta.com/next/post/sisi-religi-grace-natalie

Setiawan, Adib Rifqi. (2018, March 10). Venice Min. qureta.com. URL: https://www.qureta.com/next/post/venice-min

Setiawan, Adib Rifqi. (2018, March 11). Kisah Kasih Ayah di Balik Mata Najwa. qureta.com. URL: https://www.qureta.com/next/post/kisah-kasih-ayah-di-balik-mata-najwa

Setiawan, Adib Rifqi. (2018, March 11). Rosa Amalia Iqony. qureta.com. URL: https://www.qureta.com/next/post/rosa-amalia-iqony

Setiawan, Adib Rifqi. (2018, March 12). Clara Ng. qureta.com. URL: https://www.qureta.com/next/post/clara-ng

Setiawan, Adib Rifqi. (2018, March 14). Meniti Ilmuwati. qureta.com. URL: https://www.qureta.com/next/post/meniti-ilmuwati

Setiawan, Adib Rifqi. (2018, March 14). Surely You're Joking, Mrs. Ilmy!. qureta.com. URL: https://www.qureta.com/next/post/surely-you-re-joking-mrs-ilmy

Setiawan, Adib Rifqi. (2018, March 15). Eny R. Octaviani. qureta.com. URL: https://www.qureta.com/next/post/eny-r-octaviani

Setiawan, Adib Rifqi. (2018, March 17). Maryam Musfiroh: An Educator for Our Time. qureta.com. URL: https://www.qureta.com/next/post/maryam-musfiroh-aneducator-for-our-time

Setiawan, Adib Rifqi. (2018, March 19). Airin Rachmi Diany, Lilin Penerang Masyarakat Urban. qureta.com. URL: https://www.qureta.com/next/post/airin-rachmi-diany-lilinpenerang-masyarakat-urban

Setiawan, Adib Rifqi. (2018, March 19). Guru yang Menyapih: Catatan Perjalanan Pribadi Nong Darol Mahmada. qureta.com. URL: https://www.qureta.com/next/post/guruyang-menyapih-catatan-perjalanan-pribadi-nong-darol-mahmada

Setiawan, Adib Rifqi. (2018, March 19). Kamu dalam Aku: A Brief Story of Park Bom. qureta.com. URL: https://www.qureta.com/next/post/kamu-dalam-aku-a-brief-storyof-park-bom

Setiawan, Adib Rifqi. (2018, March 21). Bidadari di Kesunyian itu Bernama Maria Sharapova. qureta.com. URL: https://www.qureta.com/next/post/bidadari-di-kesunyianitu-bernama-maria-sharapova

Setiawan, Adib Rifqi. (2018, March 25). Novi Kaka: Sahabat, Panutan, Pembimbing. qureta.com. URL: https://www.qureta.com/next/post/novi-kaka-sahabat-panutanpembimbing

Setiawan, Adib Rifqi. (2018, May 24). Fakhrun. qureta.com. URL: https://www.qureta.com/next/post/fakhrun

Setiawan, Adib Rifqi. (2018, November 24). Penerapan Pendekatan Saintifik untuk Melatih Literasi Saintifik dalam Domain Kompetensi pada Topik Gerak Lurus di Sekolah Menengah Pertama. Seminar Nasional Fisika ke-4 (SiNaFi IV), Universitas Pendidikan Indonesia (UPI). DOI: https://dx.doi.org/10.13140/RG.2.2.23154.04809

Setiawan, Adib Rifqi. (2018, October 05). Karen Armstrong. qureta.com. URL: https://www.qureta.com/next/post/karen-armstrong

Setiawan, Adib Rifqi. (2018, September 17). Lola Zieta Azelien. qureta.com. URL: https://www.qureta.com/next/post/lola-zieta-azelien 
Setiawan, Adib Rifqi. (2019, August 21). Penyusunan Program Pembelajaran Biologi Berorientasi Literasi Saintifik. Seminar Nasional Sains \& Entrepreneurship VI (SNSE VI), Universitas PGRI Semarang (UPGRIS). DOI: https://dx.doi.org/10.13140/RG.2.2.13716.86400

Setiawan, Adib Rifqi. (2019, December 20). Literasi Saintifik Berdasarkan Kecerdasan Majemuk dan Motivasi Belajar. Media Penelitian Pendidikan: Jurnal Penelitian dalam Bidang Pendidikan dan Pengajaran, 13(02): 126-137. DOI: http://dx.doi.org/10.26877/mpp.v13i2.4913

Setiawan, Adib Rifqi. (2019, December 23). Contoh Langkah Pembelajaran Berorientasi Literasi Saintifik. santrimilenial.net. URL: https://santrimilenial.net/contoh-langkahpembelajaran-berorientasi-literasi-saintifik/

Setiawan, Adib Rifqi. (2019, December 30). Instrumen Penilaian Pembelajaran Fiqh Mu'āmalāt Berorientasi Literasi Finansial. Eklektik: Jurnal Pendidikan Ekonomi dan Kewirausahaan, 02(02): 258-272. DOI: http://dx.doi.org/10.24014/ekl.v2i2.8117

Setiawan, Adib Rifqi. (2019, June 14). Deasy Noviyanti, Perempuan Berbadan Defisit Lemak. qureta.com. URL: https://www.qureta.com/next/post/deasy-noviyantiperempuan-berbadan-defisit-lemak

Setiawan, Adib Rifqi. (2019, June 26). Peningkatan Literasi Saintifik melalui Pembelajaran Biologi Menggunakan Pendekatan Saintifik. Journal of Biology Education, 02(01): 223-235. URL: http://journal.stainkudus.ac.id/index.php/jbe/article/view/5278

Setiawan, Adib Rifqi. (2019, March 23). Penerapan Pendekatan Saintifik dalam Pembelajaran Biologi sebagai Upaya Melatih Literasi Saintifik Siswa Sekolah Menengah. Seminar Nasional Biologi 2019 Inovasi Penelitian dan Pembelajaran Biologi III (IP2B III), Universitas Negeri Surabaya (UNESA). DOI: https://dx.doi.org/10.13140/RG.2.2.19798.60484

Setiawan, Adib Rifqi. (2019, March 23). Penggunaan Naḍom Mabāī' 'Asyroh dalam Pembelajaran Biologi untuk Meningkatkan Motivasi dan Hasil Belajar. Seminar Nasional Biologi 2019 Inovasi Penelitian dan Pembelajaran Biologi III (IP2B III), Universitas Negeri Surabaya (UNESA). DOI: https://dx.doi.org/10.13140/RG.2.2.33220.37763

Setiawan, Adib Rifqi. (2019, March 23). Upaya Meningkatkan Motivasi Belajar dalam Pembelajaran Ilmu Pengetahuan Alam (IPA) Melalui Bacaan Populer. Seminar Nasional Biologi 2019 Inovasi Penelitian dan Pembelajaran Biologi III (IP2B III), Universitas Negeri Surabaya (UNESA). DOI: https://dx.doi.org/10.13140/RG.2.2.13087.71847

Setiawan, Adib Rifqi. (2019, May 07). Penerapan Pendekatan Saintifik untuk Melatih Literasi Saintifik dalam Domain Kompetensi pada Topik Gerak Lurus di Sekolah Menengah Pertama. Prosiding Seminar Nasional Fisika (SiNaFi) 2018: 7-13. URL: http://proceedings.upi.edu/index.php/sinafi/article/view/355

Setiawan, Adib Rifqi. (2019, November 23). Analisis Keabsahan dan Keandalan Science Motivation Questionnaire II (SMQ II) Versi Bahasa Indonesia. Seminar Nasional Fisika $V$ (SiNaFi 5.0), Universitas Pendidikan Indonesia (UPI). DOI: https://doi.org/10.31237/osf.io/6zeph

Setiawan, Adib Rifqi. (2019, November 23). Menyusun Instrumen Penilaian untuk Pembelajaran Topik Lingkungan Berorientasi Literasi Saintifik. Seminar Nasional Fisika $V$ (SiNaFi 5.0), Universitas Pendidikan Indonesia (UPI). DOI: https://dx.doi.org/10.35542/osf.io/sc6d2

Setiawan, Adib Rifqi. (2019, November 23). Profil Literasi Saintifik Berdasarkan Kecerdasan Majemuk dan Motivasi Belajar. Seminar Nasional Fisika V (SiNaFi 5.0), Universitas Pendidikan Indonesia (UPI). DOI: https://dx.doi.org/10.35542/osf.io/m7n95 
Setiawan, Adib Rifqi. (2019, October 02). Efektivitas Pembelajaran Biologi Berorientasi Literasi Saintifik. Thabiea : Journal of Natural Science Teaching, 02 (02): 83-94. DOI: http://dx.doi.org/10.21043/thabiea.v2i2.5345

Setiawan, Adib Rifqi. (2019, October 05). Menyusun Instrumen Penilaian untuk Pembelajaran Ekologi Berorientasi Literasi Saintifik. Seminar Nasional \& Workshop Biologi, IPA, dan Pembelajarannya ke-4 (SnoWBel IV), Universitas Negeri Malang (UM). DOI: https://dx.doi.org/10.13140/RG.2.2.21931.39206

Setiawan, Adib Rifqi. (2019, October 14). Penyusunan Program Pembelajaran Biologi Berorientasi Literasi Saintifik. Seminar Nasional Sains \& Entrepreneurship VI (SNSE VI): 255-1-8. URL: http://conference.upgris.ac.id/index.php/snse/article/view/255

Setiawan, Adib Rifqi. (2019, October 8). Biografi Clara Ng Perempuan Penulis Asal Indonesia. PsyArXiv. DOI: https://doi.org/10.31234/osf.io/yk8sx

Setiawan, Adib Rifqi. (2019, September 30). Instrumen Penilaian untuk Pembelajaran Ekologi Berorientasi Literasi Saintifik. Assimilation: Indonesian Journal of Biology Education, 02(02): 42-46. DOI: https://dx.doi.org/10.17509/aijbe.v2i2.19250

Setiawan, Adib Rifqi. (2020, April 1). Sharifah Halimah Alaydrus. Thesis Commons. DOI: https://doi.org/10.31237/osf.io/fp79c

Setiawan, Adib Rifqi. (2020, April 1). Syarifah Halimah Alaydrus. Thesis Commons. DOI: https://doi.org/10.31237/osf.io/xbmcs

Setiawan, Adib Rifqi. (2020, April 13). Commodification of the Sexuality in Kim Kardashian's Instagram Posts. Thesis Commons. URL: https://thesiscommons.org/mf7nw/

Setiawan, Adib Rifqi. (2020, April 13). مبادئ اللغة العربية. Thesis Commons. DOI: https://doi.org/10.31237/osf.io/2gvjf

Setiawan, Adib Rifqi. (2020, April 14). Commodification of the Sexuality in Kim Kardashian's Instagram Posts. SocArXiv. DOI: https://doi.org/10.31235/osf.io/kd6au

Setiawan, Adib Rifqi. (2020, April 14). Jalāl al-Dīn 'Abd al-Roḥmān ibn Abī Bakr al-Suyūṭ̂̄. SocArXiv. DOI: https://doi.org/10.31235/osf.io/5zf9v

Setiawan, Adib Rifqi. (2020, April 18). Musyāfahah al-Qur'ān Melalui Media Elektronik. Thesis Commons. URL: https://thesiscommons.org/ntjp9/

Setiawan, Adib Rifqi. (2020, April 2). Desain Pembelajaran untuk Membimbing Siswa Sekolah Dasar dalam Memperoleh Literasi Saintifik. EdArXiv. DOI: https://doi.org/10.35542/osf.io/u59f8

Setiawan, Adib Rifqi. (2020, April 2). JUPE My Uncut Story. Open Science Framework (OSF). DOI: https://doi.org/10.31219/osf.io/qdxga

Setiawan, Adib Rifqi. (2020, April 2). What is the Best Way to Analyze Pre-Post Data?. EdArXiv. DOI: https://doi.org/10.35542/osf.io/h4e6q

Setiawan, Adib Rifqi. (2020, April 20). Menyusun Instrumen Penilaian untuk Pembelajaran Ekologi Berorientasi Literasi Saintifik. Prosiding Seminar Nasional dan Workshop Biologi-IP A dan Pembelajaran Ke-4 (SnoWBel IV): 241-9. ISBN : 978-602-470-1703 \& e-ISBN : 978-602-470-171-0.

Setiawan, Adib Rifqi. (2020, April 21). Lembar Kegiatan Literasi Saintifik untuk Pembelajaran Jarak Jauh Topik Penyakit Coronavirus 2019 (COVID-19). Edukatif: Jurnal Ilmu Pendidikan, 02(01): 28-37. DOI: https://doi.org/10.31004/edukatif.v2i1.80

Setiawan, Adib Rifqi. (2020, April 3). Sharifah Halimah Alaydrus : a female preachers for our time. SocArXiv. DOI: https://doi.org/10.31235/osf.io/zb8qe

Setiawan, Adib Rifqi. (2020, April 4). Grace Natalie Louisa. SocArXiv. DOI: https://doi.org/10.31235/osf.io/zwf6g

Setiawan, Adib Rifqi. (2020, April 4). Grace Natalie Louisa. Thesis Commons. DOI: https://doi.org/10.31237/osf.io/u3mxv 
Setiawan, Adib Rifqi. (2020, April 5). The Arrogant One. Thesis Commons. DOI: https://doi.org/10.31237/osf.io/8nmku

Setiawan, Adib Rifqi. (2020, April 9). Islamic Education in Southeast Asia. EdArXiv. DOI: https://doi.org/10.35542/osf.io/dnjqv

Setiawan, Adib Rifqi. (2020, April 9). Islamic Education in Southeast Asia. Thesis Commons. DOI: https://doi.org/10.31237/osf.io/e794d

Setiawan, Adib Rifqi. (2020, February 18). Menyusun Instrumen Penilaian untuk Pembelajaran Topik Lingkungan Berorientasi Literasi Saintifik. Prosiding Seminar Nasional Fisika (SiNaFi) 2019: 15-21. URL:

http://proceedings.upi.edu/index.php/sinafi/article/view/563

Setiawan, Adib Rifqi. (2020, January 17). Penerapan Pendekatan Saintifik dalam Pembelajaran Biologi sebagai Upaya Melatih Literasi Saintifik. Prosiding Seminar Nasional Biologi 2019 Inovasi Penelitian dan Pembelajaran Biologi III (IP2B III): 140-145. URL: http://semnasbiologi.conference.unesa.ac.id/ocs/index.php/semnasbio/IP2BII I/paper/viewFile/6/19

Setiawan, Adib Rifqi. (2020, January 17). Penggunaan Mabadi 'Asyroh dalam Pembelajaran Biologi untuk Meningkatkan Motivasi dan Hasil Belajar. Prosiding Seminar Nasional Biologi 2019 Inovasi Penelitian dan Pembelajaran Biologi III (IP2B III): 158164. URL:

http://semnasbiologi.conference.unesa.ac.id/ocs/index.php/semnasbio/IP2BII I/paper/viewFile/11/21

Setiawan, Adib Rifqi. (2020, January 17). Upaya Meningkatkan Motivasi Belajar dalam Pembelajaran Ilmu Pengetahuan Alam (IPA) Melalui Bacaan Populer. Prosiding Seminar Nasional Biologi 2019 Inovasi Penelitian dan Pembelajaran Biologi III (IP2B III): 154-157. URL:

http://semnasbiologi.conference.unesa.ac.id/ocs/index.php/semnasbio/IP2BII $\mathrm{I} /$ paper/viewFile/5/51

Setiawan, Adib Rifqi. (2020, January 24). Pembelajaran Tematik Berorientasi Literasi Saintifik. Jumal Basicedu: Journal of Elementary Education, 04(01): 71-80. URL: https://jbasic.org/index.php/basicedu/article/view/298

Setiawan, Adib Rifqi. (2020, March 01). Pendidikan Literasi Finansial Melalui Pembelajaran Fiqh Mu'āmalāt Berbasis Kitab Kuning. Ną̧hruna: Jurnal Pendidikan Islam, 03(01): 138-159. DOI: https://dx.doi.org/10.31538/nzh.v3i1.522

Setiawan, Adib Rifqi. (2020, May 12). Introducing the Indonesian Education System. Thesis Commons. DOI: https://doi.org/10.31237/osf.io/ygt5c

Setiawan, Adib Rifqi. (2020, May 6). Discovering the Meaning of Fadhilaturrahmi's Work. Thesis Commons. DOI: https://doi.org/10.31237/osf.io/krf7z

Setiawan, Adib Rifqi. (2020, May 6). Menyibak Makna Karya Fadhilaturrahmi. LIS Scholarship Archive. DOI: https://doi.org/10.31229/osf.io/65y4z

Setiawan, Adib Rifqi; \& Ilmiyah, Surotul. (2020, April 13). Kecerdasan Majemuk Berdasarkan Neurosains. EdArXiv. DOI: https://doi.org/10.35542/osf.io/rj2fe

Setiawan, Adib Rifqi; \& Ilmiyah, Surotul. (2020, April 13). Multiple Intelligences Based on Neuroscience. Thesis Commons. DOI: https://doi.org/10.31237/osf.io/e9fyu

Setiawan, Adib Rifqi; \& Ilmiyah, Surotul. (2020, April 7). Lembar Kegiatan Siswa untuk Pembelajaran Jarak Jauh Berdasarkan Literasi Saintifik pada Topik Penyakit Coronavirus 2019 (COVID-19). EdArXiv. DOI: https://doi.org/10.35542/osf.io/h4632

Setiawan, Adib Rifqi; Mufassaroh, Arij Zulfi. (2019, June 28). Menyusun Soal Literasi Saintifik untuk Pembelajaran Biologi Topik Plantae dan Animalia. BIOSFER: Jurnal Biologi dan Pendidikan Biologi, 04(01): 33-40. URL: http://dx.doi.org/10.23969/biosfer.v4i1.1484 
Setiawan, Adib Rifqi; Puspaningrum, Mita; Umam, Khoirul. (2019, December 06). Pembelajaran Fiqh Mu'āmalāt Berorientasi Literasi Finansial. Tarbany: Indonesian Journal of Islamic Education, 06(02): 187-102. URL: https://ejournal.upi.edu/index.php/tarbawy/article/view/20887

Setiawan, Adib Rifqi; Saputri, Wahyu EKa. (2020, December 10). Pembelajaran Literasi Saintifik untuk Pendidikan Dasar. Media Penelitian Pendidikan : Jurnal Penelitian dalam Bidang Pendidikan dan Pengajaran, 14(02). DOI: https://doi.org/10.26877/mpp.v14i2.5794

Setiawan, Adib Rifqi; Saputri, Wahyu EKa. (2020, June 13). Science Motivation Questionnaire II (SMQ II) Versi Bahasa Indonesia. Psy ArXiv. DOI: https://doi.org/10.31234/osf.io/tac2k

Setiawan, Adib Rifqi; Utari, Setiya; Nugraha, Muhamad Gina. (2016, December 17). Mengonstruksi Rancangan Soal Domain Kompetensi Literasi Saintifik Siswa SMP Kelas VIII pada Topik Gerak Lurus. Seminar Nasional Fisika ke-2 (SiNaFi II), Universitas Pendidikan Indonesia (UPI). DOI: https://dx.doi.org/10.13140/RG.2.2.31856.10246/1

Setiawan, Adib Rifqi; Utari, Setiya; Nugraha, Muhamad Gina. (2017, September 22). Mengonstruksi Rancangan Soal Domain Kompetensi Literasi Saintifik Siswa SMP Kelas VIII pada Topik Gerak Lurus. Wahana Pendidikan Fisika, 02(02): 44 48. URL: https://ejournal.upi.edu/index.php/WPF/article/view/8277/0

Siayah, Syarofis; \& Setiawan, Adib Rifqi. (2020, April 13). A Brief Explanation of Science Education. EdArXiv. DOI: https://doi.org/10.35542/osf.io/2evn3

Siayah, Syarofis; \& Setiawan, Adib Rifqi. (2020, April 13). A Brief Explanation of Science Education. Thesis Commons. DOI: https://doi.org/10.31237/osf.io/wkvsn

Velasufah, Whasfi; \& Setiawan, Adib Rifqi. (2020, April 13). Nilai Pesantren Sebagai Dasar Pendidikan Karakter. Thesis Commons. DOI: https://doi.org/10.31237/osf.io/hq6kz

Amatullah; \& Setiawan, Adib Rifqi. (2017, October 10). Nadirsyah Hosen: berkarya sebagai diaspora. Majalah SANTRI, 7: 56-59. URL: https://issuu.com/majalahsantri/docs/santri_edisi_7/58

Feldman, DarHalevy; \& Setiawan, Adib Rifqi. (2020, April 24). Education in Israel. Thesis Commons. DOI: https://doi.org/10.31237/osf.io/62shg

Ilmiyah, Surotul; \& Setiawan, Adib Rifqi. (2020, April 7). Students' Worksheet for Distance Learning Based on Scientific Literacy in the Topic Coronavirus Disease 2019 (COVID-19). Thesis Commons. DOI: https://doi.org/10.31237/osf.io/fpg4j

Ilmiyah, Surotul; \& Setiawan, Adib Rifqi. (2020, April 7). Students' Worksheet for Distance Learning Based on Scientific Literacy in the Topic Coronavirus Disease 2019 (COVID-19). EdArXiv. DOI: https://doi.org/10.35542/osf.io/wyz5v

Setiawan, A. R. (2020, May 7). Discovering the Fundamental Problem of Four Methods to Analyze Data. Thesis Commons. DOI: https://doi.org/10.31237/osf.io/h953y

Setiawan, Adib Rifqi. (2015, November 03). Dibalik Nama Besar Albert Einstein: Dari Politik, Asmara, hingga Matematika. fisikanet.lipi.go.id. URL: http://www.fisikanet.lipi.go.id/utama.cgi?artikel\&1446556354\&2

Setiawan, Adib Rifqi. (2015, November 07). Dibalik Sampul Buku A Brief History of Time, agar pengetahuan tak hanya dinikmati ilmuwan. fisikanet.lipi.go.id. URL: http://www.fisikanet.lipi.go.id/utama.cgi?artikel\&1446855103\&2

Setiawan, Adib Rifqi. (2015, November 10). Kehidupan Asmara Hawking: raga lumpuh, jiwa masih bisa tersentuh. fisikanet.lipi.go.id. URL: http://www.fisikanet.lipi.go.id/utama.cgi?artikel\&1447145876\&2

Setiawan, Adib Rifqi. (2015, October 10). 10 Kejutan Subatomik. fisikanet.lipi.go.id. URL: http://www.fisikanet.lipi.go.id/utama.cgi?artikel\&1444577286\&3 
Setiawan, Adib Rifqi. (2015, October 31). Kurir Mikroskopis Alam Semesta bukan debu biasa. fisikanet.lipi.go.id. URL:

http://www.fisikanet.lipi.go.id/utama.cgi?artikel\&1446304060\&2

Setiawan, Adib Rifqi. (2017, February 24). Penerapan Pendekatan Saintifik untuk Melatibkan Literasi Saintifik dalam Domain Kompetensi pada Topik Gerak Lurus di Sekolah Menengah

Pertama. Undergraduate Thesis. Bandung: Universitas Pendidikan Indonesia.

URL: http://repository.upi.edu/29074/

Setiawan, Adib Rifqi. (2017, June 02). Aisha. qureta.com. URL: https://www.qureta.com/next/post/aisha-humaira

Setiawan, Adib Rifqi. (2017, June 03). Dari Yuli Hingga Julia. qureta.com. URL: https://www.qureta.com/next/post/dari-yuli-hingga-julia-2

Setiawan, Adib Rifqi. (2018, April 10). Busana: pemantas raga, pelaras jiwa. Majalah SANTRI, 8: 26-27. URL: https://issuu.com/majalahsantri/docs/majalah_santri_8/28

Setiawan, Adib Rifqi. (2018, April 10). Eny Rochmawati Octaviani: memberikan hiburan, menyuntikkan harapan. Majalah SANTRI, 8: 15-18. URL: https://issuu.com/majalahsantri/docs/majalah_santri_8/17

Setiawan, Adib Rifqi. (2018, April 10). Rosa Amalia Iqony: paduan yakin diri dan rendah hati. Majalah SANTRI, 8: 46. URL:

https://issuu.com/majalahsantri/docs/majalah_santri_8/48

Setiawan, Adib Rifqi. (2018, December 18). Irma Rahma Suwarma. qureta.com. URL: https://www.qureta.com/next/post/irma-rahma-suwarma

Setiawan, Adib Rifqi. (2018, July 03). Tangis Daniela Hantuchová. qureta.com. URL: https://www.qureta.com/next/post/tangis-daniela-hantuchova

Setiawan, Adib Rifqi. (2018, July 16). Rustriningsih, Srikandi Tersisih. qureta.com. URL: https://www.qureta.com/next/post/rustriningsih-srikandi-tersisih

Setiawan, Adib Rifqi. (2018, June 27). Ice. qureta.com. URL: https://www.qureta.com/next/post/ice

Setiawan, Adib Rifqi. (2018, June 28). Dewi Perssik. qureta.com. URL: https://www.qureta.com/next/post/dewi-perssik

Setiawan, Adib Rifqi. (2018, March 06). Breast Capital. qureta.com. URL: https://www.qureta.com/next/post/breast-capital

Setiawan, Adib Rifqi. (2018, March 06). Menyoal Vokal Duo Serigala. qureta.com. URL: https://www.qureta.com/next/post/menyoal-vokal-duo-serigala

Setiawan, Adib Rifqi. (2018, March 07). Mengenal Oza Kioza. qureta.com. URL: https://www.qureta.com/next/post/mengenal-oza-kioza

Setiawan, Adib Rifqi. (2018, March 09). Asal Usul Nama Via Vallen. qureta.com. URL: https://www.qureta.com/next/post/asal-usul-nama-via-vallen

Setiawan, Adib Rifqi. (2018, March 09). Kepedulian Airin Rachmi Diany pada Pendidikan. qureta.com. URL: https://www.qureta.com/next/post/kepedulian-airin-rachmidiany-pada-pendidikan

Setiawan, Adib Rifqi. (2018, March 09). Ketika YoonA Menyaksikan Real Madrid Menghempaskan PSG. qureta.com. URL: https://www.qureta.com/next/post/ketika-yoona-menyaksikan-real-madridmenghempaskan-psg

Setiawan, Adib Rifqi. (2018, March 09). Laila Fariha Zein (a.k.a. Uus atau Febi). qureta.com. URL: https://www.qureta.com/next/post/laila-fariha-zein-febi

Setiawan, Adib Rifqi. (2018, March 09). Pantat Perekat Umat. qureta.com. URL: https://www.qureta.com/next/post/pantat-perekat-umat

Setiawan, Adib Rifqi. (2018, March 09). Sisi Religi Grace Natalie. qureta.com. URL: https://www.qureta.com/next/post/sisi-religi-grace-natalie 
Setiawan, Adib Rifqi. (2018, March 10). Venice Min. qureta.com. URL: https://www.qureta.com/next/post/venice-min

Setiawan, Adib Rifqi. (2018, March 11). Kisah Kasih Ayah di Balik Mata Najwa. qureta.com. URL: https://www.qureta.com/next/post/kisah-kasih-ayah-di-balik-mata-najwa

Setiawan, Adib Rifqi. (2018, March 11). Rosa Amalia Iqony. qureta.com. URL: https://www.qureta.com/next/post/rosa-amalia-iqony

Setiawan, Adib Rifqi. (2018, March 12). Clara Ng. qureta.com. URL: https://www.qureta.com/next/post/clara-ng

Setiawan, Adib Rifqi. (2018, March 14). Meniti Ilmuwati. qureta.com. URL: https://www.qureta.com/next/post/meniti-ilmuwati

Setiawan, Adib Rifqi. (2018, March 14). Surely You're Joking, Mrs. Ilmy!. qureta.com. URL: https://www.qureta.com/next/post/surely-you-re-joking-mrs-ilmy

Setiawan, Adib Rifqi. (2018, March 15). Eny R. Octaviani. qureta.com. URL: https://www.qureta.com/next/post/eny-r-octaviani

Setiawan, Adib Rifqi. (2018, March 17). Maryam Musfiroh: An Educator for Our Time. qureta.com. URL: https://www.qureta.com/next/post/maryam-musfiroh-aneducator-for-our-time

Setiawan, Adib Rifqi. (2018, March 19). Airin Rachmi Diany, Lilin Penerang Masyarakat Urban. qureta.com. URL: https://www.qureta.com/next/post/airin-rachmi-diany-lilinpenerang-masyarakat-urban

Setiawan, Adib Rifqi. (2018, March 19). Guru yang Menyapih: Catatan Perjalanan Pribadi Nong Darol Mahmada. qureta.com. URL: https://www.qureta.com/next/post/guruyang-menyapih-catatan-perjalanan-pribadi-nong-darol-mahmada

Setiawan, Adib Rifqi. (2018, March 19). Kamu dalam Aku: A Brief Story of Park Bom. qureta.com. URL: https://www.qureta.com/next/post/kamu-dalam-aku-a-brief-storyof-park-bom

Setiawan, Adib Rifqi. (2018, March 21). Bidadari di Kesunyian itu Bernama Maria Sharapova. qureta.com. URL: https://www.qureta.com/next/post/bidadari-di-kesunyianitu-bernama-maria-sharapova

Setiawan, Adib Rifqi. (2018, March 25). Novi Kaka: Sahabat, Panutan, Pembimbing. qureta.com. URL: https://www.qureta.com/next/post/novi-kaka-sahabat-panutanpembimbing

Setiawan, Adib Rifqi. (2018, May 24). Fakhrun. qureta.com. URL: https://www.qureta.com/next/post/fakhrun

Setiawan, Adib Rifqi. (2018, November 24). Penerapan Pendekatan Saintifik untuk Melatih Literasi Saintifik dalam Domain Kompetensi pada Topik Gerak Lurus di Sekolah Menengah Pertama. Seminar Nasional Fisika ke-4 (SiNaFi IV), Universitas Pendidikan Indonesia (UPI). DOI: https://dx.doi.org/10.13140/RG.2.2.23154.04809

Setiawan, Adib Rifqi. (2018, October 05). Karen Armstrong. qureta.com. URL: https://www.qureta.com/next/post/karen-armstrong

Setiawan, Adib Rifqi. (2018, September 17). Lola Zieta Azelien. qureta.com. URL: https://www.qureta.com/next/post/lola-zieta-azelien

Setiawan, Adib Rifqi. (2019, August 21). Penyusunan Program Pembelajaran Biologi Berorientasi Literasi Saintifik. Seminar Nasional Sains \& Entrepreneurship VI (SNSE VI), Universitas PGRI Semarang (UPGRIS). DOI: https://dx.doi.org/10.13140/RG.2.2.13716.86400

Setiawan, Adib Rifqi. (2019, December 20). Literasi Saintifik Berdasarkan Kecerdasan Majemuk dan Motivasi Belajar. Media Penelitian Pendidikan: Jurnal Penelitian dalam Bidang Pendidikan dan Pengajaran, 13(02): 126-137. DOI: http://dx.doi.org/10.26877/mpp.v13i2.4913 
Setiawan, Adib Rifqi. (2019, December 23). Contoh Langkah Pembelajaran Berorientasi Literasi Saintifik. santrimilenial.net. URL: https://santrimilenial.net/contoh-langkahpembelajaran-berorientasi-literasi-saintifik/

Setiawan, Adib Rifqi. (2019, December 30). Instrumen Penilaian Pembelajaran Fiqh Mu'āmalāt Berorientasi Literasi Finansial. Eklektik: Jurnal Pendidikan Ekonomi dan Kewirausahaan, 02(02): 258-272. DOI: http://dx.doi.org/10.24014/ekl.v2i2.8117

Setiawan, Adib Rifqi. (2019, June 14). Deasy Noviyanti, Perempuan Berbadan Defisit Lemak. qureta.com. URL: https://www.qureta.com/next/post/deasy-noviyantiperempuan-berbadan-defisit-lemak

Setiawan, Adib Rifqi. (2019, June 26). Peningkatan Literasi Saintifik melalui Pembelajaran Biologi Menggunakan Pendekatan Saintifik. Journal of Biology Education, 02(01): 223-235.

URL: http://journal.stainkudus.ac.id/index.php/jbe/article/view/5278

Setiawan, Adib Rifqi. (2019, March 23). Penerapan Pendekatan Saintifik dalam Pembelajaran Biologi sebagai Upaya Melatih Literasi Saintifik Siswa Sekolah Menengah. Seminar Nasional Biologi 2019 Inovasi Penelitian dan Pembelajaran Biologi III (IP2B III), Universitas Negeri Surabaya (UNESA). DOI: https://dx.doi.org/10.13140/RG.2.2.19798.60484

Setiawan, Adib Rifqi. (2019, March 23). Penggunaan Naḍom Mabāī'Asyroh dalam Pembelajaran Biologi untuk Meningkatkan Motivasi dan Hasil Belajar. Seminar Nasional Biologi 2019 Inovasi Penelitian dan Pembelajaran Biologi III (IP2B III), Universitas Negeri Surabaya (UNESA). DOI: https://dx.doi.org/10.13140/RG.2.2.33220.37763

Setiawan, Adib Rifqi. (2019, March 23). Upaya Meningkatkan Motivasi Belajar dalam Pembelajaran Ilmu Pengetahuan Alam (IPA) Melalui Bacaan Populer. Seminar Nasional Biologi 2019 Inovasi Penelitian dan Pembelajaran Biologi III (IP2B III), Universitas Negeri Surabaya (UNESA). DOI: https://dx.doi.org/10.13140/RG.2.2.13087.71847

Setiawan, Adib Rifqi. (2019, May 07). Penerapan Pendekatan Saintifik untuk Melatih Literasi Saintifik dalam Domain Kompetensi pada Topik Gerak Lurus di Sekolah Menengah Pertama. Prosiding Seminar Nasional Fisika (SiNaFi) 2018: 7-13. URL: http://proceedings.upi.edu/index.php/sinafi/article/view/355

Setiawan, Adib Rifqi. (2019, November 23). Analisis Keabsahan dan Keandalan Science Motivation Questionnaire II (SMQ II) Versi Bahasa Indonesia. Seminar Nasional Fisika V (SiNaFi 5.0), Universitas Pendidikan Indonesia (UPI). DOI: https://doi.org/10.31237/osf.io/6zeph

Setiawan, Adib Rifqi. (2019, November 23). Menyusun Instrumen Penilaian untuk Pembelajaran Topik Lingkungan Berorientasi Literasi Saintifik. Seminar Nasional Fisika $V$ (SiNaFi 5.0), Universitas Pendidikan Indonesia (UPI). DOI: https://dx.doi.org/10.35542/osf.io/sc6d2

Setiawan, Adib Rifqi. (2019, November 23). Profil Literasi Saintifik Berdasarkan Kecerdasan Majemuk dan Motivasi Belajar. Seminar Nasional Fisika V (SiNaFi 5.0), Universitas Pendidikan Indonesia (UPI). DOI: https://dx.doi.org/10.35542/osf.io/m7n95

Setiawan, Adib Rifqi. (2019, October 02). Efektivitas Pembelajaran Biologi Berorientasi Literasi Saintifik. Thabiea : Journal of Natural Science Teaching, 02 (02): 83-94. DOI: http://dx.doi.org/10.21043/thabiea.v2i2.5345

Setiawan, Adib Rifqi. (2019, October 05). Menyusun Instrumen Penilaian untuk Pembelajaran Ekologi Berorientasi Literasi Saintifik. Seminar Nasional \& Workshop Biologi, IPA, dan Pembelajarannya ke-4 (SnoWBel IV), Universitas Negeri Malang (UM). DOI: https://dx.doi.org/10.13140/RG.2.2.21931.39206 
Setiawan, Adib Rifqi. (2019, October 14). Penyusunan Program Pembelajaran Biologi Berorientasi Literasi Saintifik. Seminar Nasional Sains \& Entrepreneurship VI (SNSE VI): 255-1-8. URL: http://conference.upgris.ac.id/index.php/snse/article/view/255

Setiawan, Adib Rifqi. (2019, October 8). Biografi Clara Ng Perempuan Penulis Asal Indonesia. Psy_ArXiv. DOI: https://doi.org/10.31234/osf.io/yk8sx

Setiawan, Adib Rifqi. (2019, September 30). Instrumen Penilaian untuk Pembelajaran Ekologi Berorientasi Literasi Saintifik. Assimilation: Indonesian Journal of Biology Education, 02(02): 42-46. DOI: https://dx.doi.org/10.17509/aijbe.v2i2.19250

Setiawan, Adib Rifqi. (2020, April 1). Sharifah Halimah Alaydrus. Thesis Commons. DOI: https://doi.org/10.31237/osf.io/fp79c

Setiawan, Adib Rifqi. (2020, April 1). Syarifah Halimah Alaydrus. Thesis Commons. DOI: https://doi.org/10.31237/osf.io/xbmcs

Setiawan, Adib Rifqi. (2020, April 13). Commodification of the Sexuality in Kim Kardashian's Instagram Posts. Thesis Commons. URL: https://thesiscommons.org/mf7nw/

Setiawan, Adib Rifqi. (2020, April 13). مبادئ اللغة العربية. Thesis Commons. DOI: https://doi.org/10.31237/osf.io/2gvjf

Setiawan, Adib Rifqi. (2020, April 14). Commodification of the Sexuality in Kim Kardashian's Instagram Posts. SocArXiv. DOI: https://doi.org/10.31235/osf.io/kd6au

Setiawan, Adib Rifqi. (2020, April 14). Jalāl al-Dīn 'Abd al-Roḥmān ibn Abī Bakr al-Suyūṭī. SocArXiv. DOI: https://doi.org/10.31235/osf.io/5zf9v

Setiawan, Adib Rifqi. (2020, April 18). Musyāfahah al-Qur'ān Melalui Media Elektronik. Thesis Commons. URL: https://thesiscommons.org/ntjp9/

Setiawan, Adib Rifqi. (2020, April 2). Desain Pembelajaran untuk Membimbing Siswa Sekolah Dasar dalam Memperoleh Literasi Saintifik. EdArXiv. DOI: https://doi.org/10.35542/osf.io/u59f8

Setiawan, Adib Rifqi. (2020, April 2). JUPE My Uncut Story. Open Science Framework (OSF). DOI: https://doi.org/10.31219/osf.io/qdxga

Setiawan, Adib Rifqi. (2020, April 2). What is the Best Way to Analyze Pre-Post Data?. EdArXiv. DOI: https://doi.org/10.35542/osf.io/h4e6q

Setiawan, Adib Rifqi. (2020, April 20). Menyusun Instrumen Penilaian untuk Pembelajaran Ekologi Berorientasi Literasi Saintifik. Prosiding Seminar Nasional dan Workshop Biologi-IP A dan Pembelajaran Ke-4 (SnoWBel IV): 241-9. ISBN : 978-602-470-1703 \& e-ISBN : 978-602-470-171-0.

Setiawan, Adib Rifqi. (2020, April 21). Lembar Kegiatan Literasi Saintifik untuk Pembelajaran Jarak Jauh Topik Penyakit Coronavirus 2019 (COVID-19). Edukatif: Jurnal Ilmu Pendidikan, 02(01): 28-37. DOI: https://doi.org/10.31004/edukatif.v2i1.80

Setiawan, Adib Rifqi. (2020, April 3). Sharifah Halimah Alaydrus : a female preachers for our time. SocArXiv. DOI: https://doi.org/10.31235/osf.io/zb8qe

Setiawan, Adib Rifqi. (2020, April 4). Grace Natalie Louisa. SocArXiv. DOI: https://doi.org/10.31235/osf.io/zwf6g

Setiawan, Adib Rifqi. (2020, April 4). Grace Natalie Louisa. Thesis Commons. DOI: https://doi.org/10.31237/osf.io/u3mxv

Setiawan, Adib Rifqi. (2020, April 5). The Arrogant One. Thesis Commons. DOI: https://doi.org/10.31237/osf.io/8nmku

Setiawan, Adib Rifqi. (2020, April 9). Islamic Education in Southeast Asia. EdArXiv. DOI: https://doi.org/10.35542/osf.io/dnjqv

Setiawan, Adib Rifqi. (2020, April 9). Islamic Education in Southeast Asia. Thesis Commons. DOI: https://doi.org/10.31237/osf.io/e794d

Setiawan, Adib Rifqi. (2020, February 18). Menyusun Instrumen Penilaian untuk Pembelajaran Topik Lingkungan Berorientasi Literasi Saintifik. Prosiding Seminar Nasional Fisika 
(SiNaFi) 2019: 15-21. URL:

http://proceedings.upi.edu/index.php/sinafi/article/view/563

Setiawan, Adib Rifqi. (2020, January 17). Penerapan Pendekatan Saintifik dalam Pembelajaran

Biologi sebagai Upaya Melatih Literasi Saintifik. Prosiding Seminar Nasional Biologi

2019 Inovasi Penelitian dan Pembelajaran Biologi III (IP2B III): 140-145. URL:

http://semnasbiologi.conference.unesa.ac.id/ocs/index.php/semnasbio/IP2BII I/paper/viewFile/6/19

Setiawan, Adib Rifqi. (2020, January 17). Penggunaan Mabadi 'Asyroh dalam Pembelajaran Biologi untuk Meningkatkan Motivasi dan Hasil Belajar. Prosiding Seminar

Nasional Biologi 2019 Inovasi Penelitian dan Pembelajaran Biologi III (IP2B III): 158164. URL:

http://semnasbiologi.conference.unesa.ac.id/ocs/index.php/semnasbio/IP2BII I/paper/viewFile/11/21

Setiawan, Adib Rifqi. (2020, January 17). Upaya Meningkatkan Motivasi Belajar dalam

Pembelajaran Ilmu Pengetahuan Alam (IPA) Melalui Bacaan Populer. Prosiding

Seminar Nasional Biologi 2019 Inovasi Penelitian dan Pembelajaran Biologi III (IP2B III): 154-157. URL:

http://semnasbiologi.conference.unesa.ac.id/ocs/index.php/semnasbio/IP2BII I/paper/viewFile/5/51

Setiawan, Adib Rifqi. (2020, January 24). Pembelajaran Tematik Berorientasi Literasi Saintifik. Jurnal Basicedu: Journal of Elementary Education, 04(01): 71-80. URL: https://jbasic.org/index.php/basicedu/article/view/298

Setiawan, Adib Rifqi. (2020, March 01). Pendidikan Literasi Finansial Melalui Pembelajaran Fiqh Mu'āmalāt Berbasis Kitab Kuning. Ną̧hruna: Jurnal Pendidikan Islam, 03(01): 138-159. DOI: https://dx.doi.org/10.31538/nzh.v3i1.522

Setiawan, Adib Rifqi. (2020, May 12). Introducing the Indonesian Education System. Thesis Commons. DOI: https://doi.org/10.31237/osf.io/ygt5c

Setiawan, Adib Rifqi. (2020, May 6). Discovering the Meaning of Fadhilaturrahmi's Work. Thesis Commons. DOI: https://doi.org/10.31237/osf.io/krf7z

Setiawan, Adib Rifqi. (2020, May 6). Menyibak Makna Karya Fadhilaturrahmi. LIS Scholarship Archive. DOI: https://doi.org/10.31229/osf.io/65y4z

Setiawan, Adib Rifqi; \& Ilmiyah, Surotul. (2020, April 13). Kecerdasan Majemuk Berdasarkan Neurosains. EdArXiv. DOI: https://doi.org/10.35542/osf.io/rj2fe

Setiawan, Adib Rifqi; \& Ilmiyah, Surotul. (2020, April 13). Multiple Intelligences Based on Neuroscience. Thesis Commons. DOI: https://doi.org/10.31237/osf.io/e9fyu

Setiawan, Adib Rifqi; \& Ilmiyah, Surotul. (2020, April 7). Lembar Kegiatan Siswa untuk Pembelajaran Jarak Jauh Berdasarkan Literasi Saintifik pada Topik Penyakit Coronavirus 2019 (COVID-19). EdArXiv. DOI: https://doi.org/10.35542/osf.io/h4632

Setiawan, Adib Rifqi; Mufassaroh, Arij Zulfi. (2019, June 28). Menyusun Soal Literasi Saintifik untuk Pembelajaran Biologi Topik Plantae dan Animalia. BIOSFER: Jurnal Biologi dan Pendidikan Biologi, 04(01): 33-40. URL: http://dx.doi.org/10.23969/biosfer.v4i1.1484

Setiawan, Adib Rifqi; Puspaningrum, Mita; Umam, Khoirul. (2019, December 06). Pembelajaran Fiqh Mu’āmalāt Berorientasi Literasi Finansial. Tarbany: Indonesian Journal of Islamic Education, 06(02): 187-102. URL: https://ejournal.upi.edu/index.php/tarbawy/article/view/20887

Setiawan, Adib Rifqi; Saputri, Wahyu EKa. (2020, December 10). Pembelajaran Literasi Saintifik untuk Pendidikan Dasar. Media Penelitian Pendidikan : Jurnal Penelitian dalam Bidang Pendidikan dan Pengajaran, 14(02). DOI: https://doi.org/10.26877/mpp.v14i2.5794 
Setiawan, Adib Rifqi; Saputri, Wahyu EKa. (2020, June 13). Science Motivation Questionnaire II (SMQ II) Versi Bahasa Indonesia. Psy ArXiv. DOI:

https://doi.org/10.31234/osf.io/tac2k

Setiawan, Adib Rifqi; Utari, Setiya; Nugraha, Muhamad Gina. (2016, December 17).

Mengonstruksi Rancangan Soal Domain Kompetensi Literasi Saintifik Siswa

SMP Kelas VIII pada Topik Gerak Lurus. Seminar Nasional Fisika ke-2 (SiNaFi

II), Universitas Pendidikan Indonesia (UPI). DOI:

https://dx.doi.org/10.13140/RG.2.2.31856.10246/1

Setiawan, Adib Rifqi; Utari, Setiya; Nugraha, Muhamad Gina. (2017, September 22).

Mengonstruksi Rancangan Soal Domain Kompetensi Literasi Saintifik Siswa

SMP Kelas VIII pada Topik Gerak Lurus. Wahana Pendidikan Fisika, 02(02): 44

48. URL: https:// journal.upi.edu/index.php/WPF/article/view/8277/0

Siayah, Syarofis; \& Setiawan, Adib Rifqi. (2020, April 13). A Brief Explanation of Science Education. EdArXiv. DOI: https://doi.org/10.35542/osf.io/2evn3

Siayah, Syarofis; \& Setiawan, Adib Rifqi. (2020, April 13). A Brief Explanation of Science Education. Thesis Commons. DOI: https://doi.org/10.31237/osf.io/wkvsn

Velasufah, Whasfi; \& Setiawan, Adib Rifqi. (2020, April 13). Nilai Pesantren Sebagai Dasar Pendidikan Karakter. Thesis Commons. DOI: https://doi.org/10.31237/osf.io/hq6kz

Amatullah; \& Setiawan, Adib Rifqi. (2017, October 10). Nadirsyah Hosen: berkarya sebagai diaspora. Majalab SANTRI, 7: 56-59. URL:

https://issuu.com/majalahsantri/docs/santri_edisi_7/58

Feldman, DarHalevy; \& Setiawan, Adib Rifqi. (2020, April 24). Education in Israel. Thesis Commons. DOI: https://doi.org/10.31237/osf.io/62shg

Ilmiyah, Surotul; \& Setiawan, Adib Rifqi. (2020, April 7). Students' Worksheet for Distance Learning Based on Scientific Literacy in the Topic Coronavirus Disease 2019 (COVID-19). Thesis Commons. DOI: https://doi.org/10.31237/osf.io/fpg4j

Ilmiyah, Surotul; \& Setiawan, Adib Rifqi. (2020, April 7). Students' Worksheet for Distance Learning Based on Scientific Literacy in the Topic Coronavirus Disease 2019 (COVID-19). EdArXiv. DOI: https://doi.org/10.35542/osf.io/wyz5v

Setiawan, A. R. (2020, May 7). Discovering the Fundamental Problem of Four Methods to Analyze Data. Thesis Commons. DOI: https://doi.org/10.31237/osf.io/h953y

Setiawan, Adib Rifqi. (2015, November 03). Dibalik Nama Besar Albert Einstein: Dari Politik, Asmara, hingga Matematika. fisikanet.lipi.go.id. URL: http://www.fisikanet.lipi.go.id/utama.cgi?artikel\&1446556354\&2

Setiawan, Adib Rifqi. (2015, November 07). Dibalik Sampul Buku A Brief History of Time, agar pengetahuan tak hanya dinikmati ilmuwan. fisikanet.lipi.go.id. URL: http://www.fisikanet.lipi.go.id/utama.cgi?artikel\&1446855103\&2

Setiawan, Adib Rifqi. (2015, November 10). Kehidupan Asmara Hawking: raga lumpuh, jiwa masih bisa tersentuh. fisikanet.lipi.go.id. URL: http://www.fisikanet.lipi.go.id/utama.cgi?artikel\&1447145876\&2

Setiawan, Adib Rifqi. (2015, October 10). 10 Kejutan Subatomik. fisikanet.lipi.go.id. URL: http://www.fisikanet.lipi.go.id/utama.cgi?artikel\&1444577286\&3

Setiawan, Adib Rifqi. (2015, October 31). Kurir Mikroskopis Alam Semesta bukan debu biasa. fisikanet.lipi.go.id. URL: http://www.fisikanet.lipi.go.id/utama.cgi?artikel\&1446304060\&2

Setiawan, Adib Rifqi. (2017, February 24). Penerapan Pendekatan Saintifik untuk Melatibkan Literasi Saintifik dalam Domain Kompetensi pada Topik. Gerak Lurus di Sekolah Menengah Pertama. Undergraduate Thesis. Bandung: Universitas Pendidikan Indonesia. URL: http://repository.upi.edu/29074/ 
Setiawan, Adib Rifqi. (2017, June 02). Aisha. qureta.com. URL:

https://www.qureta.com/next/post/aisha-humaira

Setiawan, Adib Rifqi. (2017, June 03). Dari Yuli Hingga Julia. qureta.com. URL: https://www.qureta.com/next/post/dari-yuli-hingga-julia-2

Setiawan, Adib Rifqi. (2018, April 10). Busana: pemantas raga, pelaras jiwa. Majalab SANTRI, 8: 26-27. URL: https://issuu.com/majalahsantri/docs/majalah_santri_8/28

Setiawan, Adib Rifqi. (2018, April 10). Eny Rochmawati Octaviani: memberikan hiburan, menyuntikkan harapan. Majalah SANTRI, 8: 15-18. URL: https://issuu.com/majalahsantri/docs/majalah_santri_8/17

Setiawan, Adib Rifqi. (2018, April 10). Rosa Amalia Iqony: paduan yakin diri dan rendah hati. Majalah SANTRI, 8: 46. URL: https://issuu.com/majalahsantri/docs/majalah_santri_8/48

Setiawan, Adib Rifqi. (2018, December 18). Irma Rahma Suwarma. qureta.com. URL: https://www.qureta.com/next/post/irma-rahma-suwarma

Setiawan, Adib Rifqi. (2018, July 03). Tangis Daniela Hantuchová. qureta.com. URL: https://www.qureta.com/next/post/tangis-daniela-hantuchova

Setiawan, Adib Rifqi. (2018, July 16). Rustriningsih, Srikandi Tersisih. qureta.com. URL: https://www.qureta.com/next/post/rustriningsih-srikandi-tersisih

Setiawan, Adib Rifqi. (2018, June 27). Ice. qureta.com. URL: https://www.qureta.com/next/post/ice

Setiawan, Adib Rifqi. (2018, June 28). Dewi Perssik. qureta.com. URL: https://www.qureta.com/next/post/dewi-perssik

Setiawan, Adib Rifqi. (2018, March 06). Breast Capital. qureta.com. URL: https://www.qureta.com/next/post/breast-capital

Setiawan, Adib Rifqi. (2018, March 06). Menyoal Vokal Duo Serigala. qureta.com. URL: https://www.qureta.com/next/post/menyoal-vokal-duo-serigala

Setiawan, Adib Rifqi. (2018, March 07). Mengenal Oza Kioza. qureta.com. URL: https://www.qureta.com/next/post/mengenal-oza-kioza

Setiawan, Adib Rifqi. (2018, March 09). Asal Usul Nama Via Vallen. qureta.com. URL: https://www.qureta.com/next/post/asal-usul-nama-via-vallen

Setiawan, Adib Rifqi. (2018, March 09). Kepedulian Airin Rachmi Diany pada Pendidikan. qureta.com. URL: https://www.qureta.com/next/post/kepedulian-airin-rachmidiany-pada-pendidikan

Setiawan, Adib Rifqi. (2018, March 09). Ketika YoonA Menyaksikan Real Madrid Menghempaskan PSG. qureta.com. URL:

https://www.qureta.com/next/post/ketika-yoona-menyaksikan-real-madridmenghempaskan-psg

Setiawan, Adib Rifqi. (2018, March 09). Laila Fariha Zein (a.k.a. Uus atau Febi). qureta.com. URL: https://www.qureta.com/next/post/laila-fariha-zein-febi

Setiawan, Adib Rifqi. (2018, March 09). Pantat Perekat Umat. qureta.com. URL: https://www.qureta.com/next/post/pantat-perekat-umat

Setiawan, Adib Rifqi. (2018, March 09). Sisi Religi Grace Natalie. qureta.com. URL: https://www.qureta.com/next/post/sisi-religi-grace-natalie

Setiawan, Adib Rifqi. (2018, March 10). Venice Min. qureta.com. URL: https://www.qureta.com/next/post/venice-min

Setiawan, Adib Rifqi. (2018, March 11). Kisah Kasih Ayah di Balik Mata Najwa. qureta.com. URL: https://www.qureta.com/next/post/kisah-kasih-ayah-di-balik-mata-najwa

Setiawan, Adib Rifqi. (2018, March 11). Rosa Amalia Iqony. qureta.com. URL: https://www.qureta.com/next/post/rosa-amalia-iqony

Setiawan, Adib Rifqi. (2018, March 12). Clara Ng. qureta.com. URL: https://www.qureta.com/next/post/clara-ng 
Setiawan, Adib Rifqi. (2018, March 14). Meniti Ilmuwati. qureta.com. URL: https://www.qureta.com/next/post/meniti-ilmuwati

Setiawan, Adib Rifqi. (2018, March 14). Surely You're Joking, Mrs. Ilmy!. qureta.com. URL: https://www.qureta.com/next/post/surely-you-re-joking-mrs-ilmy

Setiawan, Adib Rifqi. (2018, March 15). Eny R. Octaviani. qureta.com. URL: https://www.qureta.com/next/post/eny-r-octaviani

Setiawan, Adib Rifqi. (2018, March 17). Maryam Musfiroh: An Educator for Our Time. qureta.com. URL: https://www.qureta.com/next/post/maryam-musfiroh-aneducator-for-our-time

Setiawan, Adib Rifqi. (2018, March 19). Airin Rachmi Diany, Lilin Penerang Masyarakat Urban. qureta.com. URL: https://www.qureta.com/next/post/airin-rachmi-diany-lilinpenerang-masyarakat-urban

Setiawan, Adib Rifqi. (2018, March 19). Guru yang Menyapih: Catatan Perjalanan Pribadi Nong Darol Mahmada. qureta.com. URL: https://www.qureta.com/next/post/guruyang-menyapih-catatan-perjalanan-pribadi-nong-darol-mahmada

Setiawan, Adib Rifqi. (2018, March 19). Kamu dalam Aku: A Brief Story of Park Bom. qureta.com. URL: https://www.qureta.com/next/post/kamu-dalam-aku-a-brief-storyof-park-bom

Setiawan, Adib Rifqi. (2018, March 21). Bidadari di Kesunyian itu Bernama Maria Sharapova. qureta.com. URL: https://www.qureta.com/next/post/bidadari-di-kesunyianitu-bernama-maria-sharapova

Setiawan, Adib Rifqi. (2018, March 25). Novi Kaka: Sahabat, Panutan, Pembimbing. qureta.com. URL: https://www.qureta.com/next/post/novi-kaka-sahabat-panutanpembimbing

Setiawan, Adib Rifqi. (2018, May 24). Fakhrun. qureta.com. URL: https://www.qureta.com/next/post/fakhrun

Setiawan, Adib Rifqi. (2018, November 24). Penerapan Pendekatan Saintifik untuk Melatih Literasi Saintifik dalam Domain Kompetensi pada Topik Gerak Lurus di Sekolah Menengah Pertama. Seminar Nasional Fisika ke-4 (SiNaFi IV), Universitas Pendidikan Indonesia (UPI). DOI: https://dx.doi.org/10.13140/RG.2.2.23154.04809

Setiawan, Adib Rifqi. (2018, October 05). Karen Armstrong. qureta.com. URL: https://www.qureta.com/next/post/karen-armstrong

Setiawan, Adib Rifqi. (2018, September 17). Lola Zieta Azelien. qureta.com. URL: https://www.qureta.com/next/post/lola-zieta-azelien

Setiawan, Adib Rifqi. (2019, August 21). Penyusunan Program Pembelajaran Biologi Berorientasi Literasi Saintifik. Seminar Nasional Sains \& Entrepreneurship VI (SNSE VI), Universitas PGRI Semarang (UPGRIS). DOI: https://dx.doi.org/10.13140/RG.2.2.13716.86400

Setiawan, Adib Rifqi. (2019, December 20). Literasi Saintifik Berdasarkan Kecerdasan Majemuk dan Motivasi Belajar. Media Penelitian Pendidikan: Jurnal Penelitian dalam Bidang Pendidikan dan Pengajaran, 13(02): 126-137. DOI: http://dx.doi.org/10.26877/mpp.v13i2.4913

Setiawan, Adib Rifqi. (2019, December 23). Contoh Langkah Pembelajaran Berorientasi Literasi Saintifik. santrimilenial.net. URL: https://santrimilenial.net/contoh-langkahpembelajaran-berorientasi-literasi-saintifik/

Setiawan, Adib Rifqi. (2019, December 30). Instrumen Penilaian Pembelajaran Fiqh Mu'āmalāt Berorientasi Literasi Finansial. Eklektik: Jurnal Pendidikan Ekonomi dan Kewirausahaan, 02(02): 258-272. DOI: http://dx.doi.org/10.24014/ekl.v2i2.8117 
Setiawan, Adib Rifqi. (2019, June 14). Deasy Noviyanti, Perempuan Berbadan Defisit Lemak. qureta.com. URL: https://www.qureta.com/next/post/deasy-noviyantiperempuan-berbadan-defisit-lemak

Setiawan, Adib Rifqi. (2019, June 26). Peningkatan Literasi Saintifik melalui Pembelajaran Biologi Menggunakan Pendekatan Saintifik. Journal of Biology Education, 02(01): 223-235. URL: http://journal.stainkudus.ac.id/index.php/jbe/article/view/5278

Setiawan, Adib Rifqi. (2019, March 23). Penerapan Pendekatan Saintifik dalam Pembelajaran Biologi sebagai Upaya Melatih Literasi Saintifik Siswa Sekolah Menengah. Seminar Nasional Biologi 2019 Inovasi Penelitian dan Pembelajaran Biologi III (IP2B III), Universitas Negeri Surabaya (UNESA). DOI: https://dx.doi.org/10.13140/RG.2.2.19798.60484

Setiawan, Adib Rifqi. (2019, March 23). Penggunaan Naḍom Mabāī' 'Asyroh dalam Pembelajaran Biologi untuk Meningkatkan Motivasi dan Hasil Belajar. Seminar Nasional Biologi 2019 Inovasi Penelitian dan Pembelajaran Biologi III (IP2B III), Universitas Negeri Surabaya (UNESA). DOI: https://dx.doi.org/10.13140/RG.2.2.33220.37763

Setiawan, Adib Rifqi. (2019, March 23). Upaya Meningkatkan Motivasi Belajar dalam Pembelajaran Ilmu Pengetahuan Alam (IPA) Melalui Bacaan Populer. Seminar Nasional Biologi 2019 Inovasi Penelitian dan Pembelajaran Biologi III (IP2B III), Universitas Negeri Surabaya (UNESA). DOI: https://dx.doi.org/10.13140/RG.2.2.13087.71847

Setiawan, Adib Rifqi. (2019, May 07). Penerapan Pendekatan Saintifik untuk Melatih Literasi Saintifik dalam Domain Kompetensi pada Topik Gerak Lurus di Sekolah Menengah Pertama. Prosiding Seminar Nasional Fisika (SiNaFi) 2018: 7-13. URL: http://proceedings.upi.edu/index.php/sinafi/article/view/355

Setiawan, Adib Rifqi. (2019, November 23). Analisis Keabsahan dan Keandalan Science Motivation Questionnaire II (SMQ II) Versi Bahasa Indonesia. Seminar Nasional Fisika V (SiNaFi 5.0), Universitas Pendidikan Indonesia (UPI). DOI: https://doi.org/10.31237/osf.io/6zeph

Setiawan, Adib Rifqi. (2019, November 23). Menyusun Instrumen Penilaian untuk Pembelajaran Topik Lingkungan Berorientasi Literasi Saintifik. Seminar Nasional Fisika $V$ (SiNaFi 5.0), Universitas Pendidikan Indonesia (UPI). DOI: https://dx.doi.org/10.35542/osf.io/sc6d2

Setiawan, Adib Rifqi. (2019, November 23). Profil Literasi Saintifik Berdasarkan Kecerdasan Majemuk dan Motivasi Belajar. Seminar Nasional Fisika V (SiNaFi 5.0), Universitas Pendidikan Indonesia (UPI). DOI: https://dx.doi.org/10.35542/osf.io/m7n95

Setiawan, Adib Rifqi. (2019, October 02). Efektivitas Pembelajaran Biologi Berorientasi Literasi Saintifik. Thabiea : Journal of Natural Science Teaching, 02 (02): 83-94. DOI: http://dx.doi.org/10.21043/thabiea.v2i2.5345

Setiawan, Adib Rifqi. (2019, October 05). Menyusun Instrumen Penilaian untuk Pembelajaran Ekologi Berorientasi Literasi Saintifik. Seminar Nasional \& Workshop Biologi, IP A, dan Pembelajarannya ke-4 (SnoWBel IV), Universitas Negeri Malang (UM). DOI: https://dx.doi.org/10.13140/RG.2.2.21931.39206

Setiawan, Adib Rifqi. (2019, October 14). Penyusunan Program Pembelajaran Biologi Berorientasi Literasi Saintifik. Seminar Nasional Sains \& Entrepreneurship VI (SNSE VI): 255-1-8. URL: http://conference.upgris.ac.id/index.php/snse/article/view/255

Setiawan, Adib Rifqi. (2019, October 8). Biografi Clara Ng Perempuan Penulis Asal Indonesia. PsyArXiv. DOI: https://doi.org/10.31234/osf.io/yk8sx 
Setiawan, Adib Rifqi. (2019, September 30). Instrumen Penilaian untuk Pembelajaran Ekologi Berorientasi Literasi Saintifik. Assimilation: Indonesian Journal of Biology Education, 02(02): 42-46. DOI: https://dx.doi.org/10.17509/aijbe.v2i2.19250

Setiawan, Adib Rifqi. (2020, April 1). Sharifah Halimah Alaydrus. Thesis Commons. DOI: https://doi.org/10.31237/osf.io/fp79c

Setiawan, Adib Rifqi. (2020, April 1). Syarifah Halimah Alaydrus. Thesis Commons. DOI: https://doi.org/10.31237/osf.io/xbmcs

Setiawan, Adib Rifqi. (2020, April 13). Commodification of the Sexuality in Kim Kardashian's Instagram Posts. Thesis Commons. URL: https://thesiscommons.org/mf7nw/

Setiawan, Adib Rifqi. (2020, April 13). مبادئ اللغة العربية. Thesis Commons. DOI: https://doi.org/10.31237/osf.io/2gvjf

Setiawan, Adib Rifqi. (2020, April 14). Commodification of the Sexuality in Kim Kardashian's Instagram Posts. SocArXiv. DOI: https://doi.org/10.31235/osf.io/kd6au

Setiawan, Adib Rifqi. (2020, April 14). Jalāl al-Dīn 'Abd al-Roḥmān ibn Abī Bakr al-Suyūṭ̂̄. SocArXiv. DOI: https://doi.org/10.31235/osf.io/5zf9v

Setiawan, Adib Rifqi. (2020, April 18). Musyāfahah al-Qur'ān Melalui Media Elektronik. Thesis Commons. URL: https://thesiscommons.org/ntjp9/

Setiawan, Adib Rifqi. (2020, April 2). Desain Pembelajaran untuk Membimbing Siswa Sekolah Dasar dalam Memperoleh Literasi Saintifik. EdArXiv. DOI: https://doi.org/10.35542/osf.io/u59f8

Setiawan, Adib Rifqi. (2020, April 2). JUPE My Uncut Story. Open Science Framework (OSF). DOI: https://doi.org/10.31219/osf.io/qdxga

Setiawan, Adib Rifqi. (2020, April 2). What is the Best Way to Analyze Pre-Post Data?. EdArXiv. DOI: https://doi.org/10.35542/osf.io/h4e6q

Setiawan, Adib Rifqi. (2020, April 20). Menyusun Instrumen Penilaian untuk Pembelajaran Ekologi Berorientasi Literasi Saintifik. Prosiding Seminar Nasional dan Workshop Biologi-IP A dan Pembelajaran Ke-4 (SnoWBel IV): 241-9. ISBN : 978-602-470-1703 \& e-ISBN : 978-602-470-171-0.

Setiawan, Adib Rifqi. (2020, April 21). Lembar Kegiatan Literasi Saintifik untuk Pembelajaran Jarak Jauh Topik Penyakit Coronavirus 2019 (COVID-19). Edukatif: Jurnal Ilmu Pendidikan, 02(01): 28-37. DOI: https://doi.org/10.31004/edukatif.v2i1.80

Setiawan, Adib Rifqi. (2020, April 3). Sharifah Halimah Alaydrus : a female preachers for our time. SocArXiv. DOI: https://doi.org/10.31235/osf.io/zb8qe

Setiawan, Adib Rifqi. (2020, April 4). Grace Natalie Louisa. SocArXiv. DOI: https://doi.org/10.31235/osf.io/zwf6g

Setiawan, Adib Rifqi. (2020, April 4). Grace Natalie Louisa. Thesis Commons. DOI: https://doi.org/10.31237/osf.io/u3mxv

Setiawan, Adib Rifqi. (2020, April 5). The Arrogant One. Thesis Commons. DOI: https://doi.org/10.31237/osf.io/8nmku

Setiawan, Adib Rifqi. (2020, April 9). Islamic Education in Southeast Asia. EdArXiv. DOI: https://doi.org/10.35542/osf.io/dnjqv

Setiawan, Adib Rifqi. (2020, April 9). Islamic Education in Southeast Asia. Thesis Commons. DOI: https://doi.org/10.31237/osf.io/e794d

Setiawan, Adib Rifqi. (2020, February 18). Menyusun Instrumen Penilaian untuk Pembelajaran Topik Lingkungan Berorientasi Literasi Saintifik. Prosiding Seminar Nasional Fisika (SiNaFi) 2019: 15-21. URL:

http://proceedings.upi.edu/index.php/sinafi/article/view/563

Setiawan, Adib Rifqi. (2020, January 17). Penerapan Pendekatan Saintifik dalam Pembelajaran Biologi sebagai Upaya Melatih Literasi Saintifik. Prosiding Seminar Nasional Biologi 2019 Inovasi Penelitian dan Pembelajaran Biologi III (IP2B III): 140-145. URL: 
http://semnasbiologi.conference.unesa.ac.id/ocs/index.php/semnasbio/IP2BII I/paper/viewFile/6/19

Setiawan, Adib Rifqi. (2020, January 17). Penggunaan Mabadi 'Asyroh dalam Pembelajaran Biologi untuk Meningkatkan Motivasi dan Hasil Belajar. Prosiding Seminar Nasional Biologi 2019 Inovasi Penelitian dan Pembelajaran Biologi III (IP2B III): 158164. URL:

http://semnasbiologi.conference.unesa.ac.id/ocs/index.php/semnasbio/IP2BII $\mathrm{I} /$ paper/viewFile/11/21

Setiawan, Adib Rifqi. (2020, January 17). Upaya Meningkatkan Motivasi Belajar dalam Pembelajaran Ilmu Pengetahuan Alam (IPA) Melalui Bacaan Populer. Prosiding Seminar Nasional Biologi 2019 Inovasi Penelitian dan Pembelajaran Biologi III (IP2B III): 154-157. URL: http://semnasbiologi.conference.unesa.ac.id/ocs/index.php/semnasbio/IP2BII I/paper/viewFile/5/51

Setiawan, Adib Rifqi. (2020, January 24). Pembelajaran Tematik Berorientasi Literasi Saintifik. Jurnal Basicedu: Journal of Elementary Education, 04(01): 71-80. URL: https://jbasic.org/index.php/basicedu/article/view/298

Setiawan, Adib Rifqi. (2020, March 01). Pendidikan Literasi Finansial Melalui Pembelajaran Fiqh Mu'āmalāt Berbasis Kitab Kuning. Ną̧hruna: Jurnal Pendidikan Islam, 03(01): 138-159. DOI: https://dx.doi.org/10.31538/nzh.v3i1.522

Setiawan, Adib Rifqi. (2020, May 12). Introducing the Indonesian Education System. Thesis Commons. DOI: https://doi.org/10.31237/osf.io/ygt5c

Setiawan, Adib Rifqi. (2020, May 6). Discovering the Meaning of Fadhilaturrahmi's Work. Thesis Commons. DOI: https://doi.org/10.31237/osf.io/krf7z

Setiawan, Adib Rifqi. (2020, May 6). Menyibak Makna Karya Fadhilaturrahmi. LIS Scholarship Archive. DOI: https://doi.org/10.31229/osf.io/65y4z

Setiawan, Adib Rifqi; \& Ilmiyah, Surotul. (2020, April 13). Kecerdasan Majemuk Berdasarkan Neurosains. EdArXiv. DOI: https://doi.org/10.35542/osf.io/rj2fe

Setiawan, Adib Rifqi; \& Ilmiyah, Surotul. (2020, April 13). Multiple Intelligences Based on Neuroscience. Thesis Commons. DOI: https://doi.org/10.31237/osf.io/e9fyu

Setiawan, Adib Rifqi; \& Ilmiyah, Surotul. (2020, April 7). Lembar Kegiatan Siswa untuk Pembelajaran Jarak Jauh Berdasarkan Literasi Saintifik pada Topik Penyakit Coronavirus 2019 (COVID-19). EdArXiv. DOI: https://doi.org/10.35542/osf.io/h4632

Setiawan, Adib Rifqi; Mufassaroh, Arij Zulfi. (2019, June 28). Menyusun Soal Literasi Saintifik untuk Pembelajaran Biologi Topik Plantae dan Animalia. BIOSFER: Jurnal Biologi dan Pendidikan Biologi, 04(01): 33-40. URL: http://dx.doi.org/10.23969/biosfer.v4i1.1484

Setiawan, Adib Rifqi; Puspaningrum, Mita; Umam, Khoirul. (2019, December 06). Pembelajaran Fiqh Mu'āmalāt Berorientasi Literasi Finansial. Tarbany: Indonesian Journal of Islamic Education, 06(02): 187-102. URL: https://ejournal.upi.edu/index.php/tarbawy/article/view/20887

Setiawan, Adib Rifqi; Saputri, Wahyu EKa. (2020, December 10). Pembelajaran Literasi Saintifik untuk Pendidikan Dasar. Media Penelitian Pendidikan : Jurnal Penelitian dalam Bidang Pendidikan dan Pengajaran, 14(02). DOI: https://doi.org/10.26877/mpp.v14i2.5794

Setiawan, Adib Rifqi; Saputri, Wahyu EKa. (2020, June 13). Science Motivation Questionnaire II (SMQ II) Versi Bahasa Indonesia. PsyArXiv. DOI: https://doi.org/10.31234/osf.io/tac2k

Setiawan, Adib Rifai; Utari, Setiya; Nugraha, Muhamad Gina. (2016, December 17). Mengonstruksi Rancangan Soal Domain Kompetensi Literasi Saintifik Siswa 
SMP Kelas VIII pada Topik Gerak Lurus. Seminar Nasional Fisika kee-2 (SiNaFi II), Universitas Pendidikan Indonesia (UPI). DOI: https://dx.doi.org/10.13140/RG.2.2.31856.10246/1

Setiawan, Adib Rifqi; Utari, Setiya; Nugraha, Muhamad Gina. (2017, September 22).

Mengonstruksi Rancangan Soal Domain Kompetensi Literasi Saintifik Siswa SMP Kelas VIII pada Topik Gerak Lurus. Wahana Pendidikan Fisika, 02(02): 44 48. URL: https://ejournal.upi.edu/index.php/WPF/article/view/8277/0

Siayah, Syarofis; \& Setiawan, Adib Rifqi. (2020, April 13). A Brief Explanation of Science Education. EdArXiv. DOI: https://doi.org/10.35542/osf.io/2evn3

Siayah, Syarofis; \& Setiawan, Adib Rifqi. (2020, April 13). A Brief Explanation of Science Education. Thesis Commons. DOI: https://doi.org/10.31237/osf.io/wkvsn

Velasufah, Whasfi; \& Setiawan, Adib Rifqi. (2020, April 13). Nilai Pesantren Sebagai Dasar Pendidikan Karakter. Thesis Commons. DOI: https://doi.org/10.31237/osf.io/hq6kz

Amatullah; \& Setiawan, Adib Rifqi. (2017, October 10). Nadirsyah Hosen: berkarya sebagai diaspora. Majalab SANTRI, 7: 56-59 . URL: https://issuu.com/majalahsantri/docs/santri_edisi_7/58

Feldman, DarHalevy; \& Setiawan, Adib Rifqi. (2020, April 24). Education in Israel. Thesis Commons. DOI: https://doi.org/10.31237/osf.io/62shg

Ilmiyah, Surotul; \& Setiawan, Adib Rifqi. (2020, April 7). Students' Worksheet for Distance Learning Based on Scientific Literacy in the Topic Coronavirus Disease 2019 (COVID-19). Thesis Commons. DOI: https://doi.org/10.31237/osf.io/fpg4j

Ilmiyah, Surotul; \& Setiawan, Adib Rifqi. (2020, April 7). Students' Worksheet for Distance Learning Based on Scientific Literacy in the Topic Coronavirus Disease 2019 (COVID-19). EdArXiv. DOI: https://doi.org/10.35542/osf.io/wyz5v

Setiawan, A. R. (2020, May 7). Discovering the Fundamental Problem of Four Methods to Analyze Data. Thesis Commons. DOI: https://doi.org/10.31237/osf.io/h953y

Setiawan, Adib Rifqi. (2015, November 03). Dibalik Nama Besar Albert Einstein: Dari Politik, Asmara, hingga Matematika. fisikanet.lipi.go.id. URL: http://www.fisikanet.lipi.go.id/utama.cgi?artikel\&1446556354\&2

Setiawan, Adib Rifqi. (2015, November 07). Dibalik Sampul Buku A Brief History of Time, agar pengetahuan tak hanya dinikmati ilmuwan. fisikanet.lipi.go.id. URL: http://www.fisikanet.lipi.go.id/utama.cgi?artikel\&1446855103\&2

Setiawan, Adib Rifqi. (2015, November 10). Kehidupan Asmara Hawking: raga lumpuh, jiwa masih bisa tersentuh. fisikanet.lipi.go.id. URL: http://www.fisikanet.lipi.go.id/utama.cgi?artikel\&1447145876\&2

Setiawan, Adib Rifqi. (2015, October 10). 10 Kejutan Subatomik. fisikanet.lipi.go.id. URL: http://www.fisikanet.lipi.go.id/utama.cgi?artikel\&1444577286\&3

Setiawan, Adib Rifqi. (2015, October 31). Kurir Mikroskopis Alam Semesta bukan debu biasa. fisikanet.lipi.go.id. URL: http://www.fisikanet.lipi.go.id/utama.cgi?artikel\&1446304060\&2

Setiawan, Adib Rifqi. (2017, February 24). Penerapan Pendekatan Saintifik untuk Melatibkan Literasi Saintifik dalam Domain Kompetensi pada Topik Gerak Lurus di Sekolah Menengah Pertama. Undergraduate Thesis. Bandung: Universitas Pendidikan Indonesia. URL: http://repository.upi.edu/29074/

Setiawan, Adib Rifqi. (2017, June 02). Aisha. qureta.com. URL: https://www.qureta.com/next/post/aisha-humaira

Setiawan, Adib Rifqi. (2017, June 03). Dari Yuli Hingga Julia. qureta.com. URL: https://www.qureta.com/next/post/dari-yuli-hingga-julia-2

Setiawan, Adib Rifqi. (2018, April 10). Busana: pemantas raga, pelaras jiwa. Majalab SANTRI, 8: 26-27. URL: https://issuu.com/majalahsantri/docs/majalah_santri_8/28 
Setiawan, Adib Rifqi. (2018, April 10). Eny Rochmawati Octaviani: memberikan hiburan, menyuntikkan harapan. Majalah SANTRI, 8: 15-18. URL: https://issuu.com/majalahsantri/docs/majalah_santri_8/17

Setiawan, Adib Rifqi. (2018, April 10). Rosa Amalia Iqony: paduan yakin diri dan rendah hati. Majalah SANTRI, 8: 46. URL: https://issuu.com/majalahsantri/docs/majalah_santri_8/48

Setiawan, Adib Rifqi. (2018, December 18). Irma Rahma Suwarma. qureta.com. URL: https://www.qureta.com/next/post/irma-rahma-suwarma

Setiawan, Adib Rifqi. (2018, July 03). Tangis Daniela Hantuchová. qureta.com. URL: https://www.qureta.com/next/post/tangis-daniela-hantuchova

Setiawan, Adib Rifqi. (2018, July 16). Rustriningsih, Srikandi Tersisih. qureta.com. URL: https://www.qureta.com/next/post/rustriningsih-srikandi-tersisih

Setiawan, Adib Rifqi. (2018, June 27). Ice. qureta.com. URL: https://www.qureta.com/next/post/ice

Setiawan, Adib Rifqi. (2018, June 28). Dewi Perssik. qureta.com. URL: https://www.qureta.com/next/post/dewi-perssik

Setiawan, Adib Rifqi. (2018, March 06). Breast Capital. qureta.com. URL: https://www.qureta.com/next/post/breast-capital

Setiawan, Adib Rifqi. (2018, March 06). Menyoal Vokal Duo Serigala. qureta.com. URL: https://www.qureta.com/next/post/menyoal-vokal-duo-serigala

Setiawan, Adib Rifqi. (2018, March 07). Mengenal Oza Kioza. qureta.com. URL: https://www.qureta.com/next/post/mengenal-oza-kioza

Setiawan, Adib Rifqi. (2018, March 09). Asal Usul Nama Via Vallen. qureta.com. URL: https://www.qureta.com/next/post/asal-usul-nama-via-vallen

Setiawan, Adib Rifqi. (2018, March 09). Kepedulian Airin Rachmi Diany pada Pendidikan. qureta.com. URL: https://www.qureta.com/next/post/kepedulian-airin-rachmidiany-pada-pendidikan

Setiawan, Adib Rifqi. (2018, March 09). Ketika YoonA Menyaksikan Real Madrid Menghempaskan PSG. qureta.com. URL: https://www.qureta.com/next/post/ketika-yoona-menyaksikan-real-madridmenghempaskan-psg

Setiawan, Adib Rifqi. (2018, March 09). Laila Fariha Zein (a.k.a. Uus atau Febi). qureta.com. URL: https://www.qureta.com/next/post/laila-fariha-zein-febi

Setiawan, Adib Rifqi. (2018, March 09). Pantat Perekat Umat. qureta.com. URL: https://www.qureta.com/next/post/pantat-perekat-umat

Setiawan, Adib Rifqi. (2018, March 09). Sisi Religi Grace Natalie. qureta.com. URL: https://www.qureta.com/next/post/sisi-religi-grace-natalie

Setiawan, Adib Rifqi. (2018, March 10). Venice Min. qureta.com. URL: https://www.qureta.com/next/post/venice-min

Setiawan, Adib Rifqi. (2018, March 11). Kisah Kasih Ayah di Balik Mata Najwa. qureta.com. URL: https://www.qureta.com/next/post/kisah-kasih-ayah-di-balik-mata-najwa

Setiawan, Adib Rifqi. (2018, March 11). Rosa Amalia Iqony. qureta.com. URL: https://www.qureta.com/next/post/rosa-amalia-iqony

Setiawan, Adib Rifqi. (2018, March 12). Clara Ng. qureta.com. URL: https://www.qureta.com/next/post/clara-ng

Setiawan, Adib Rifqi. (2018, March 14). Meniti Ilmuwati. qureta.com. URL: https://www.qureta.com/next/post/meniti-ilmuwati

Setiawan, Adib Rifqi. (2018, March 14). Surely You're Joking, Mrs. Ilmy!. qureta.com. URL: https://www.qureta.com/next/post/surely-you-re-joking-mrs-ilmy

Setiawan, Adib Rifqi. (2018, March 15). Eny R. Octaviani. qureta.com. URL: https://www.qureta.com/next/post/eny-r-octaviani 
Setiawan, Adib Rifqi. (2018, March 17). Maryam Musfiroh: An Educator for Our Time. qureta.com. URL: https://www.qureta.com/next/post/maryam-musfiroh-aneducator-for-our-time

Setiawan, Adib Rifqi. (2018, March 19). Airin Rachmi Diany, Lilin Penerang Masyarakat Urban. qureta.com. URL: https://www.qureta.com/next/post/airin-rachmi-diany-lilinpenerang-masyarakat-urban

Setiawan, Adib Rifqi. (2018, March 19). Guru yang Menyapih: Catatan Perjalanan Pribadi Nong Darol Mahmada. qureta.com. URL: https://www.qureta.com/next/post/guruyang-menyapih-catatan-perjalanan-pribadi-nong-darol-mahmada

Setiawan, Adib Rifqi. (2018, March 19). Kamu dalam Aku: A Brief Story of Park Bom. qureta.com. URL: https://www.qureta.com/next/post/kamu-dalam-aku-a-brief-storyof-park-bom

Setiawan, Adib Rifqi. (2018, March 21). Bidadari di Kesunyian itu Bernama Maria Sharapova. qureta.com. URL: https://www.qureta.com/next/post/bidadari-di-kesunyianitu-bernama-maria-sharapova

Setiawan, Adib Rifqi. (2018, March 25). Novi Kaka: Sahabat, Panutan, Pembimbing. qureta.com. URL: https://www.qureta.com/next/post/novi-kaka-sahabat-panutanpembimbing

Setiawan, Adib Rifqi. (2018, May 24). Fakhrun. qureta.com. URL: https://www.qureta.com/next/post/fakhrun

Setiawan, Adib Rifqi. (2018, November 24). Penerapan Pendekatan Saintifik untuk Melatih Literasi Saintifik dalam Domain Kompetensi pada Topik Gerak Lurus di Sekolah Menengah Pertama. Seminar Nasional Fisika ke-4 (SiNaFi IV), Universitas Pendidikan Indonesia (UPI). DOI: https://dx.doi.org/10.13140/RG.2.2.23154.04809

Setiawan, Adib Rifqi. (2018, October 05). Karen Armstrong. qureta.com. URL: https://www.qureta.com/next/post/karen-armstrong

Setiawan, Adib Rifqi. (2018, September 17). Lola Zieta Azelien. qureta.com. URL: https://www.qureta.com/next/post/lola-zieta-azelien

Setiawan, Adib Rifqi. (2019, August 21). Penyusunan Program Pembelajaran Biologi Berorientasi Literasi Saintifik. Seminar Nasional Sains \& Entrepreneurship VI (SNSE VI), Universitas PGRI Semarang (UPGRIS). DOI: https://dx.doi.org/10.13140/RG.2.2.13716.86400

Setiawan, Adib Rifqi. (2019, December 20). Literasi Saintifik Berdasarkan Kecerdasan Majemuk dan Motivasi Belajar. Media Penelitian Pendidikan: Jurnal Penelitian dalam Bidang Pendidikan dan Pengajaran, 13(02): 126-137. DOI: http://dx.doi.org/10.26877/mpp.v13i2.4913

Setiawan, Adib Rifqi. (2019, December 23). Contoh Langkah Pembelajaran Berorientasi Literasi Saintifik. santrimilenial.net. URL: https://santrimilenial.net/contoh-langkahpembelajaran-berorientasi-literasi-saintifik/

Setiawan, Adib Rifqi. (2019, December 30). Instrumen Penilaian Pembelajaran Fiqh Mu'āmalāt Berorientasi Literasi Finansial. Eklektik: Jurnal Pendidikan Ekonomi dan Kewirausahaan, 02(02): 258-272. DOI: http://dx.doi.org/10.24014/ekl.v2i2.8117

Setiawan, Adib Rifqi. (2019, June 14). Deasy Noviyanti, Perempuan Berbadan Defisit Lemak. qureta.com. URL: https://www.qureta.com/next/post/deasy-noviyantiperempuan-berbadan-defisit-lemak

Setiawan, Adib Rifqi. (2019, June 26). Peningkatan Literasi Saintifik melalui Pembelajaran Biologi Menggunakan Pendekatan Saintifik. Journal of Biology Education, 02(01): 223-235.

URL: http://journal.stainkudus.ac.id/index.php/jbe/article/view/5278

Setiawan, Adib Rifqi. (2019, March 23). Penerapan Pendekatan Saintifik dalam Pembelajaran Biologi sebagai Upaya Melatih Literasi Saintifik Siswa Sekolah Menengah. 
Seminar Nasional Biologi 2019 Inovasi Penelitian dan Pembelajaran Biologi III (IP2B III), Universitas Negeri Surabaya (UNESA). DOI:

https:/ /dx.doi.org/10.13140/RG.2.2.19798.60484

Setiawan, Adib Rifqi. (2019, March 23). Penggunaan Naḍom Mabāī' 'Asyroh dalam

Pembelajaran Biologi untuk Meningkatkan Motivasi dan Hasil Belajar. Seminar

Nasional Biologi 2019 Inovasi Penelitian dan Pembelajaran Biologi III (IP2B III),

Universitas Negeri Surabaya (UNESA). DOI:

https://dx.doi.org/10.13140/RG.2.2.33220.37763

Setiawan, Adib Rifqi. (2019, March 23). Upaya Meningkatkan Motivasi Belajar dalam

Pembelajaran Ilmu Pengetahuan Alam (IPA) Melalui Bacaan Populer. Seminar

Nasional Biologi 2019 Inovasi Penelitian dan Pembelajaran Biologi III (IP2B III),

Universitas Negeri Surabaya (UNESA). DOI:

https://dx.doi.org/10.13140/RG.2.2.13087.71847

Setiawan, Adib Rifqi. (2019, May 07). Penerapan Pendekatan Saintifik untuk Melatih Literasi

Saintifik dalam Domain Kompetensi pada Topik Gerak Lurus di Sekolah

Menengah Pertama. Prosiding Seminar Nasional Fisika (SiNaFi) 2018: 7-13. URL:

http://proceedings.upi.edu/index.php/sinafi/article/view/355

Setiawan, Adib Rifqi. (2019, November 23). Analisis Keabsahan dan Keandalan Science

Motivation Questionnaire II (SMQ II) Versi Bahasa Indonesia. Seminar Nasional

Fisika $V$ (SiNaFi 5.0), Universitas Pendidikan Indonesia (UPI). DOI: https://doi.org/10.31237/osf.io/6zeph

Setiawan, Adib Rifqi. (2019, November 23). Menyusun Instrumen Penilaian untuk Pembelajaran Topik Lingkungan Berorientasi Literasi Saintifik. Seminar Nasional Fisika $V$ (SiNaFi 5.0), Universitas Pendidikan Indonesia (UPI). DOI:

https://dx.doi.org/10.35542/osf.io/sc6d2

Setiawan, Adib Rifqi. (2019, November 23). Profil Literasi Saintifik Berdasarkan Kecerdasan

Majemuk dan Motivasi Belajar. Seminar Nasional Fisika V (SiNaFi 5.0),

Universitas Pendidikan Indonesia (UPI). DOI:

https://dx.doi.org/10.35542/osf.io/m7n95

Setiawan, Adib Rifqi. (2019, October 02). Efektivitas Pembelajaran Biologi Berorientasi Literasi

Saintifik. Thabiea : Journal of Natural Science Teaching, 02 (02): 83-94. DOI:

http://dx.doi.org/10.21043/thabiea.v2i2.5345

Setiawan, Adib Rifqi. (2019, October 05). Menyusun Instrumen Penilaian untuk Pembelajaran Ekologi Berorientasi Literasi Saintifik. Seminar Nasional \& Workshop Biologi, IPA, dan Pembelajarannya ke-4 (SnoWBel IV), Universitas Negeri Malang (UM). DOI: https://dx.doi.org/10.13140/RG.2.2.21931.39206

Setiawan, Adib Rifqi. (2019, October 14). Penyusunan Program Pembelajaran Biologi Berorientasi Literasi Saintifik. Seminar Nasional Sains \& Entrepreneurship VI (SNSE VI): 255-1-8. URL: http://conference.upgris.ac.id/index.php/snse/article/view/255

Setiawan, Adib Rifqi. (2019, October 8). Biografi Clara Ng Perempuan Penulis Asal Indonesia. Psy/ArXiv. DOI: https://doi.org/10.31234/osf.io/yk8sx

Setiawan, Adib Rifqi. (2019, September 30). Instrumen Penilaian untuk Pembelajaran Ekologi Berorientasi Literasi Saintifik. Assimilation: Indonesian Journal of Biology Education, 02(02): 42-46. DOI: https://dx.doi.org/10.17509/aijbe.v2i2.19250

Setiawan, Adib Rifqi. (2020, April 1). Sharifah Halimah Alaydrus. Thesis Commons. DOI: https://doi.org/10.31237/osf.io/fp79c

Setiawan, Adib Rifqi. (2020, April 1). Syarifah Halimah Alaydrus. Thesis Commons. DOI: https://doi.org/10.31237/osf.io/xbmcs

Setiawan, Adib Rifqi. (2020, April 13). Commodification of the Sexuality in Kim Kardashian's Instagram Posts. Thesis Commons. URL: https://thesiscommons.org/mf7nw/ 
Setiawan, Adib Rifqi. (2020, April 13). مبادئ اللغة العربية. Thesis Commons. DOI: https://doi.org/10.31237/osf.io/2gvjf

Setiawan, Adib Rifqi. (2020, April 14). Commodification of the Sexuality in Kim Kardashian's Instagram Posts. SocArXiv. DOI: https://doi.org/10.31235/osf.io/kd6au

Setiawan, Adib Rifqi. (2020, April 14). Jalāl al-Dīn 'Abd al-Roḥmān ibn Abī Bakr al-Suyūṭ̣̂. SocArXiv. DOI: https://doi.org/10.31235/osf.io/5zf9v

Setiawan, Adib Rifqi. (2020, April 18). Musyāfahah al-Qur'ān Melalui Media Elektronik. Thesis Commons. URL: https://thesiscommons.org/ntjp9/

Setiawan, Adib Rifqi. (2020, April 2). Desain Pembelajaran untuk Membimbing Siswa Sekolah Dasar dalam Memperoleh Literasi Saintifik. EdArXiv. DOI: https://doi.org/10.35542/osf.io/u59f8

Setiawan, Adib Rifqi. (2020, April 2). JUPE My Uncut Story. Open Science Framework (OSF). DOI: https://doi.org/10.31219/osf.io/qdxga

Setiawan, Adib Rifqi. (2020, April 2). What is the Best Way to Analyze Pre-Post Data?. EdArXiv. DOI: https://doi.org/10.35542/osf.io/h4e6q

Setiawan, Adib Rifqi. (2020, April 20). Menyusun Instrumen Penilaian untuk Pembelajaran Ekologi Berorientasi Literasi Saintifik. Prosiding Seminar Nasional dan Workshop Biologi-IP A dan Pembelajaran Ke-4 (SnoWBel IV): 241-9. ISBN : 978-602-470-1703 \& e-ISBN : 978-602-470-171-0.

Setiawan, Adib Rifqi. (2020, April 21). Lembar Kegiatan Literasi Saintifik untuk Pembelajaran Jarak Jauh Topik Penyakit Coronavirus 2019 (COVID-19). Edukatif: Jumal Ilmu Pendidikan, 02(01): 28-37. DOI: https://doi.org/10.31004/edukatif.v2i1.80

Setiawan, Adib Rifqi. (2020, April 3). Sharifah Halimah Alaydrus : a female preachers for our time. SocArXiv. DOI: https://doi.org/10.31235/osf.io/zb8qe

Setiawan, Adib Rifqi. (2020, April 4). Grace Natalie Louisa. SocArXiv. DOI: https://doi.org/10.31235/osf.io/zwf6g

Setiawan, Adib Rifqi. (2020, April 4). Grace Natalie Louisa. Thesis Commons. DOI: https://doi.org/10.31237/osf.io/u3mxv

Setiawan, Adib Rifqi. (2020, April 5). The Arrogant One. Thesis Commons. DOI: https://doi.org/10.31237/osf.io/8nmku

Setiawan, Adib Rifqi. (2020, April 9). Islamic Education in Southeast Asia. EdArXiv. DOI: https://doi.org/10.35542/osf.io/dnjqv

Setiawan, Adib Rifqi. (2020, April 9). Islamic Education in Southeast Asia. Thesis Commons. DOI: https://doi.org/10.31237/osf.io/e794d

Setiawan, Adib Rifqi. (2020, February 18). Menyusun Instrumen Penilaian untuk Pembelajaran Topik Lingkungan Berorientasi Literasi Saintifik. Prosiding Seminar Nasional Fisika (SiNaFi) 2019: 15-21. URL:

http://proceedings.upi.edu/index.php/sinafi/article/view/563

Setiawan, Adib Rifqi. (2020, January 17). Penerapan Pendekatan Saintifik dalam Pembelajaran Biologi sebagai Upaya Melatih Literasi Saintifik. Prosiding Seminar Nasional Biologi 2019 Inovasi Penelitian dan Pembelajaran Biologi III (IP2B III): 140-145. URL: http://semnasbiologi.conference.unesa.ac.id/ocs/index.php/semnasbio/IP2BII I/paper/viewFile/6/19

Setiawan, Adib Rifqi. (2020, January 17). Penggunaan Mabadi 'Asyroh dalam Pembelajaran Biologi untuk Meningkatkan Motivasi dan Hasil Belajar. Prosiding Seminar Nasional Biologi 2019 Inovasi Penelitian dan Pembelajaran Biologi III (IP2B III): 158164. URL:

http://semnasbiologi.conference.unesa.ac.id/ocs/index.php/semnasbio/IP2BII I/paper/viewFile/11/21

Setiawan, Adib Rifqi. (2020, January 17). Upaya Meningkatkan Motivasi Belajar dalam Pembelajaran Ilmu Pengetahuan Alam (IPA) Melalui Bacaan Populer. Prosiding 
Seminar Nasional Biologi 2019 Inovasi Penelitian dan Pembelajaran Biologi III (IP2B III): 154-157. URL:

http://semnasbiologi.conference.unesa.ac.id/ocs/index.php/semnasbio/IP2BII I/paper/viewFile/5/51

Setiawan, Adib Rifqi. (2020, January 24). Pembelajaran Tematik Berorientasi Literasi Saintifik. Jurnal Basicedu: Journal of Elementary Education, 04(01): 71-80. URL: https://jbasic.org/index.php/basicedu/article/view/298

Setiawan, Adib Rifqi. (2020, March 01). Pendidikan Literasi Finansial Melalui Pembelajaran Fiqh Mu'āmalāt Berbasis Kitab Kuning. Ną̧hruna: Jurnal Pendidikan Islam, 03(01): 138-159. DOI: https://dx.doi.org/10.31538/nzh.v3i1.522

Setiawan, Adib Rifqi. (2020, May 12). Introducing the Indonesian Education System. Thesis Commons. DOI: https://doi.org/10.31237/osf.io/ygt5c

Setiawan, Adib Rifqi. (2020, May 6). Discovering the Meaning of Fadhilaturrahmi's Work. Thesis Commons. DOI: https://doi.org/10.31237/osf.io/krf7z

Setiawan, Adib Rifqi. (2020, May 6). Menyibak Makna Karya Fadhilaturrahmi. LIS Scholarship Archive. DOI: https://doi.org/10.31229/osf.io/65y4z

Setiawan, Adib Rifqi; \& Ilmiyah, Surotul. (2020, April 13). Kecerdasan Majemuk Berdasarkan Neurosains. EdArXiv. DOI: https://doi.org/10.35542/osf.io/rj2fe

Setiawan, Adib Rifqi; \& Ilmiyah, Surotul. (2020, April 13). Multiple Intelligences Based on Neuroscience. Thesis Commons. DOI: https://doi.org/10.31237/osf.io/e9fyu

Setiawan, Adib Rifqi; \& Ilmiyah, Surotul. (2020, April 7). Lembar Kegiatan Siswa untuk Pembelajaran Jarak Jauh Berdasarkan Literasi Saintifik pada Topik Penyakit Coronavirus 2019 (COVID-19). EdArXiv. DOI: https://doi.org/10.35542/osf.io/h4632

Setiawan, Adib Rifqi; Mufassaroh, Arij Zulfi. (2019, June 28). Menyusun Soal Literasi Saintifik untuk Pembelajaran Biologi Topik Plantae dan Animalia. BIOSFER: Jurnal Biologi dan Pendidikan Biologi, 04(01): 33-40. URL: http://dx.doi.org/10.23969/biosfer.v4i1.1484

Setiawan, Adib Rifqi; Puspaningrum, Mita; Umam, Khoirul. (2019, December 06). Pembelajaran Fiqh Mu'āmalāt Berorientasi Literasi Finansial. Tarbany: Indonesian Journal of Islamic Education, 06(02): 187-102. URL: https:// ejournal.upi.edu/index.php/tarbawy/article/view/20887

Setiawan, Adib Rifqi; Saputri, Wahyu EKa. (2020, December 10). Pembelajaran Literasi Saintifik untuk Pendidikan Dasar. Media Penelitian Pendidikan : Jurnal Penelitian dalam Bidang Pendidikan dan Pengajaran, 14(02). DOI: https://doi.org/10.26877/mpp.v14i2.5794

Setiawan, Adib Rifai; Saputri, Wahyu EKa. (2020, June 13). Science Motivation Questionnaire II (SMQ II) Versi Bahasa Indonesia. Psy ArXiv. DOI: https://doi.org/10.31234/osf.io/tac2k

Setiawan, Adib Rifqi; Utari, Setiya; Nugraha, Muhamad Gina. (2016, December 17). Mengonstruksi Rancangan Soal Domain Kompetensi Literasi Saintifik Siswa SMP Kelas VIII pada Topik Gerak Lurus. Seminar Nasional Fisika ke-2 (SiNaFi II), Universitas Pendidikan Indonesia (UPI). DOI: https://dx.doi.org/10.13140/RG.2.2.31856.10246/1

Setiawan, Adib Rifqi; Utari, Setiya; Nugraha, Muhamad Gina. (2017, September 22). Mengonstruksi Rancangan Soal Domain Kompetensi Literasi Saintifik Siswa SMP Kelas VIII pada Topik Gerak Lurus. Wahana Pendidikan Fisika, 02(02): 44 48. URL: https:// ejournal.upi.edu/index.php/WPF/article/view/8277/0

Siayah, Syarofis; \& Setiawan, Adib Rifqi. (2020, April 13). A Brief Explanation of Science Education. EdArXiv. DOI: https://doi.org/10.35542/osf.io/2evn3 
Siayah, Syarofis; \& Setiawan, Adib Rifqi. (2020, April 13). A Brief Explanation of Science Education. Thesis Commons. DOI: https://doi.org/10.31237/osf.io/wkvsn

Velasufah, Whasfi; \& Setiawan, Adib Rifqi. (2020, April 13). Nilai Pesantren Sebagai Dasar Pendidikan Karakter. Thesis Commons. DOI: https://doi.org/10.31237/osf.io/hq6kz

Amatullah; \& Setiawan, Adib Rifqi. (2017, October 10). Nadirsyah Hosen: berkarya sebagai diaspora. Majalab SANTRI, 7: 56-59. URL: https://issuu.com/majalahsantri/docs/santri_edisi_7/58

Feldman, DarHalevy; \& Setiawan, Adib Rifqi. (2020, April 24). Education in Israel. Thesis Commons. DOI: https://doi.org/10.31237/osf.io/62shg

Ilmiyah, Surotul; \& Setiawan, Adib Rifqi. (2020, April 7). Students' Worksheet for Distance Learning Based on Scientific Literacy in the Topic Coronavirus Disease 2019 (COVID-19). Thesis Commons. DOI: https://doi.org/10.31237/osf.io/fpg4j

Ilmiyah, Surotul; \& Setiawan, Adib Rifqi. (2020, April 7). Students' Worksheet for Distance Learning Based on Scientific Literacy in the Topic Coronavirus Disease 2019 (COVID-19). EdArXiv. DOI: https://doi.org/10.35542/osf.io/wyz5v

Setiawan, A. R. (2020, May 7). Discovering the Fundamental Problem of Four Methods to Analyze Data. Thesis Commons. DOI: https://doi.org/10.31237/osf.io/h953y

Setiawan, Adib Rifqi. (2015, November 03). Dibalik Nama Besar Albert Einstein: Dari Politik, Asmara, hingga Matematika. fisikanet.lipi.go.id. URL:

http://www.fisikanet.lipi.go.id/utama.cgi?artikel\&1446556354\&2

Setiawan, Adib Rifqi. (2015, November 07). Dibalik Sampul Buku A Brief History of Time, agar pengetahuan tak hanya dinikmati ilmuwan. fisikanet.lipi.go.id. URL: http://www.fisikanet.lipi.go.id/utama.cgi?artikel\&1446855103\&2

Setiawan, Adib Rifqi. (2015, November 10). Kehidupan Asmara Hawking: raga lumpuh, jiwa masih bisa tersentuh. fisikanet.lipi.go.id. URL: http://www.fisikanet.lipi.go.id/utama.cgi?artikel\&1447145876\&2

Setiawan, Adib Rifqi. (2015, October 10). 10 Kejutan Subatomik. fisikanet.lipi.go.id. URL: http:/ /www.fisikanet.lipi.go.id/utama.cgi?artikel\&1444577286\&3

Setiawan, Adib Rifqi. (2015, October 31). Kurir Mikroskopis Alam Semesta bukan debu biasa. fisikeanet.lipi.go.id. URL: http://www.fisikanet.lipi.go.id/utama.cgi?artikel\&1446304060\&2

Setiawan, Adib Rifqi. (2017, February 24). Penerapan Pendekatan Saintifik untuk. Melatibkan Literasi Saintifik dalam Domain Kompetensi pada Topik Gerak Lurus di Sekolah Menengah Pertama. Undergraduate Thesis. Bandung: Universitas Pendidikan Indonesia. URL: http://repository.upi.edu/29074/

Setiawan, Adib Rifqi. (2017, June 02). Aisha. qureta.com. URL: https://www.qureta.com/next/post/aisha-humaira

Setiawan, Adib Rifqi. (2017, June 03). Dari Yuli Hingga Julia. qureta.com. URL: https://www.qureta.com/next/post/dari-yuli-hingga-julia-2

Setiawan, Adib Rifqi. (2018, April 10). Busana: pemantas raga, pelaras jiwa. Majalab SANTRI, 8: 26-27. URL: https://issuu.com/majalahsantri/docs/majalah_santri_8/28

Setiawan, Adib Rifqi. (2018, April 10). Eny Rochmawati Octaviani: memberikan hiburan, menyuntikkan harapan. Majalah SANTRI, 8: 15-18. URL: https://issuu.com/majalahsantri/docs/majalah_santri_8/17

Setiawan, Adib Rifqi. (2018, April 10). Rosa Amalia Iqony: paduan yakin diri dan rendah hati. Majalah SANTRI, 8: 46. URL: https://issuu.com/majalahsantri/docs/majalah_santri_8/48

Setiawan, Adib Rifqi. (2018, December 18). Irma Rahma Suwarma. qureta.com. URL: https://www.qureta.com/next/post/irma-rahma-suwarma 
Setiawan, Adib Rifqi. (2018, July 03). Tangis Daniela Hantuchová. qureta.com. URL: https://www.qureta.com/next/post/tangis-daniela-hantuchova

Setiawan, Adib Rifqi. (2018, July 16). Rustriningsih, Srikandi Tersisih. qureta.com. URL: https://www.qureta.com/next/post/rustriningsih-srikandi-tersisih

Setiawan, Adib Rifqi. (2018, June 27). Ice. qureta.com. URL: https://www.qureta.com/next/post/ice

Setiawan, Adib Rifqi. (2018, June 28). Dewi Perssik. qureta.com. URL: https://www.qureta.com/next/post/dewi-perssik

Setiawan, Adib Rifqi. (2018, March 06). Breast Capital. qureta.com. URL: https://www.qureta.com/next/post/breast-capital

Setiawan, Adib Rifqi. (2018, March 06). Menyoal Vokal Duo Serigala. qureta.com. URL: https://www.qureta.com/next/post/menyoal-vokal-duo-serigala

Setiawan, Adib Rifqi. (2018, March 07). Mengenal Oza Kioza. qureta.com. URL: https://www.qureta.com/next/post/mengenal-oza-kioza

Setiawan, Adib Rifqi. (2018, March 09). Asal Usul Nama Via Vallen. qureta.com. URL: https://www.qureta.com/next/post/asal-usul-nama-via-vallen

Setiawan, Adib Rifqi. (2018, March 09). Kepedulian Airin Rachmi Diany pada Pendidikan. qureta.com. URL: https://www.qureta.com/next/post/kepedulian-airin-rachmidiany-pada-pendidikan

Setiawan, Adib Rifqi. (2018, March 09). Ketika YoonA Menyaksikan Real Madrid Menghempaskan PSG. qureta.com. URL:

https://www.qureta.com/next/post/ketika-yoona-menyaksikan-real-madridmenghempaskan-psg

Setiawan, Adib Rifqi. (2018, March 09). Laila Fariha Zein (a.k.a. Uus atau Febi). qureta.com. URL: https://www.qureta.com/next/post/laila-fariha-zein-febi

Setiawan, Adib Rifqi. (2018, March 09). Pantat Perekat Umat. qureta.com. URL: https://www.qureta.com/next/post/pantat-perekat-umat

Setiawan, Adib Rifqi. (2018, March 09). Sisi Religi Grace Natalie. qureta.com. URL: https://www.qureta.com/next/post/sisi-religi-grace-natalie

Setiawan, Adib Rifqi. (2018, March 10). Venice Min. qureta.com. URL: https://www.qureta.com/next/post/venice-min

Setiawan, Adib Rifqi. (2018, March 11). Kisah Kasih Ayah di Balik Mata Najwa. qureta.com. URL: https://www.qureta.com/next/post/kisah-kasih-ayah-di-balik-mata-najwa

Setiawan, Adib Rifqi. (2018, March 11). Rosa Amalia Iqony. qureta.com. URL: https://www.qureta.com/next/post/rosa-amalia-iqony

Setiawan, Adib Rifqi. (2018, March 12). Clara Ng. qureta.com. URL: https://www.qureta.com/next/post/clara-ng

Setiawan, Adib Rifqi. (2018, March 14). Meniti Ilmuwati. qureta.com. URL: https://www.qureta.com/next/post/meniti-ilmuwati

Setiawan, Adib Rifqi. (2018, March 14). Surely You're Joking, Mrs. Ilmy!. qureta.com. URL: https://www.qureta.com/next/post/surely-you-re-joking-mrs-ilmy

Setiawan, Adib Rifqi. (2018, March 15). Eny R. Octaviani. qureta.com. URL: https://www.qureta.com/next/post/eny-r-octaviani

Setiawan, Adib Rifqi. (2018, March 17). Maryam Musfiroh: An Educator for Our Time. qureta.com. URL: https://www.qureta.com/next/post/maryam-musfiroh-aneducator-for-our-time

Setiawan, Adib Rifqi. (2018, March 19). Airin Rachmi Diany, Lilin Penerang Masyarakat Urban. qureta.com. URL: https://www.qureta.com/next/post/airin-rachmi-diany-lilinpenerang-masyarakat-urban 
Setiawan, Adib Rifqi. (2018, March 19). Guru yang Menyapih: Catatan Perjalanan Pribadi Nong Darol Mahmada. qureta.com. URL: https://www.qureta.com/next/post/guruyang-menyapih-catatan-perjalanan-pribadi-nong-darol-mahmada

Setiawan, Adib Rifqi. (2018, March 19). Kamu dalam Aku: A Brief Story of Park Bom. qureta.com. URL: https://www.qureta.com/next/post/kamu-dalam-aku-a-brief-storyof-park-bom

Setiawan, Adib Rifqi. (2018, March 21). Bidadari di Kesunyian itu Bernama Maria Sharapova. qureta.com. URL: https://www.qureta.com/next/post/bidadari-di-kesunyianitu-bernama-maria-sharapova

Setiawan, Adib Rifqi. (2018, March 25). Novi Kaka: Sahabat, Panutan, Pembimbing. qureta.com. URL: https://www.qureta.com/next/post/novi-kaka-sahabat-panutanpembimbing

Setiawan, Adib Rifqi. (2018, May 24). Fakhrun. qureta.com. URL: https://www.qureta.com/next/post/fakhrun

Setiawan, Adib Rifqi. (2018, November 24). Penerapan Pendekatan Saintifik untuk Melatih Literasi Saintifik dalam Domain Kompetensi pada Topik Gerak Lurus di Sekolah Menengah Pertama. Seminar Nasional Fisika ke-4 (SiNaFi IV), Universitas Pendidikan Indonesia (UPI). DOI: https://dx.doi.org/10.13140/RG.2.2.23154.04809

Setiawan, Adib Rifqi. (2018, October 05). Karen Armstrong. qureta.com. URL: https://www.qureta.com/next/post/karen-armstrong

Setiawan, Adib Rifqi. (2018, September 17). Lola Zieta Azelien. qureta.com. URL: https://www.qureta.com/next/post/lola-zieta-azelien

Setiawan, Adib Rifqi. (2019, August 21). Penyusunan Program Pembelajaran Biologi Berorientasi Literasi Saintifik. Seminar Nasional Sains \& Entrepreneurship VI (SNSE VI), Universitas PGRI Semarang (UPGRIS). DOI: https://dx.doi.org/10.13140/RG.2.2.13716.86400

Setiawan, Adib Rifqi. (2019, December 20). Literasi Saintifik Berdasarkan Kecerdasan Majemuk dan Motivasi Belajar. Media Penelitian Pendidikan: Jurnal Penelitian dalam Bidang Pendidikan dan Pengajaran, 13(02): 126-137. DOI: http://dx.doi.org/10.26877/mpp.v13i2.4913

Setiawan, Adib Rifqi. (2019, December 23). Contoh Langkah Pembelajaran Berorientasi Literasi Saintifik. santrimilenial.net. URL: https://santrimilenial.net/contoh-langkahpembelajaran-berorientasi-literasi-saintifik/

Setiawan, Adib Rifqi. (2019, December 30). Instrumen Penilaian Pembelajaran Fiqh Mu'āmalāt Berorientasi Literasi Finansial. Eklektik: Jurnal Pendidikan Ekonomi dan Kewirausahaan, 02(02): 258-272. DOI: http://dx.doi.org/10.24014/ekl.v2i2.8117

Setiawan, Adib Rifqi. (2019, June 14). Deasy Noviyanti, Perempuan Berbadan Defisit Lemak. qureta.com. URL: https://www.qureta.com/next/post/deasy-noviyantiperempuan-berbadan-defisit-lemak

Setiawan, Adib Rifqi. (2019, June 26). Peningkatan Literasi Saintifik melalui Pembelajaran Biologi Menggunakan Pendekatan Saintifik. Journal of Biology Education, 02(01): 223-235. URL: http://journal.stainkudus.ac.id/index.php/jbe/article/view/5278

Setiawan, Adib Rifqi. (2019, March 23). Penerapan Pendekatan Saintifik dalam Pembelajaran Biologi sebagai Upaya Melatih Literasi Saintifik Siswa Sekolah Menengah. Seminar Nasional Biologi 2019 Inovasi Penelitian dan Pembelajaran Biologi III (IP2B III), Universitas Negeri Surabaya (UNESA). DOI: https://dx.doi.org/10.13140/RG.2.2.19798.60484

Setiawan, Adib Rifqi. (2019, March 23). Penggunaan Naḍom Mabadī' 'Asyroh dalam Pembelajaran Biologi untuk Meningkatkan Motivasi dan Hasil Belajar. Seminar Nasional Biologi 2019 Inovasi Penelitian dan Pembelajaran Biologi III (IP2B III), 
Universitas Negeri Surabaya (UNESA). DOI:

https://dx.doi.org/10.13140/RG.2.2.33220.37763

Setiawan, Adib Rifqi. (2019, March 23). Upaya Meningkatkan Motivasi Belajar dalam

Pembelajaran Ilmu Pengetahuan Alam (IPA) Melalui Bacaan Populer. Seminar

Nasional Biologi 2019 Inovasi Penelitian dan Pembelajaran Biologi III (IP2B III),

Universitas Negeri Surabaya (UNESA). DOI:

https://dx.doi.org/10.13140/RG.2.2.13087.71847

Setiawan, Adib Rifqi. (2019, May 07). Penerapan Pendekatan Saintifik untuk Melatih Literasi

Saintifik dalam Domain Kompetensi pada Topik Gerak Lurus di Sekolah

Menengah Pertama. Prosiding Seminar Nasional Fisika (SiNaFi) 2018: 7-13. URL:

http://proceedings.upi.edu/index.php/sinafi/article/view/355

Setiawan, Adib Rifqi. (2019, November 23). Analisis Keabsahan dan Keandalan Science

Motivation Questionnaire II (SMQ II) Versi Bahasa Indonesia. Seminar Nasional

Fisika V (SiNaFi 5.0), Universitas Pendidikan Indonesia (UPI). DOI:

https://doi.org/10.31237/osf.io/6zeph

Setiawan, Adib Rifqi. (2019, November 23). Menyusun Instrumen Penilaian untuk Pembelajaran

Topik Lingkungan Berorientasi Literasi Saintifik. Seminar Nasional Fisika $V$

(SiNaFi 5.0), Universitas Pendidikan Indonesia (UPI). DOI:

https://dx.doi.org/10.35542/osf.io/sc6d2

Setiawan, Adib Rifqi. (2019, November 23). Profil Literasi Saintifik Berdasarkan Kecerdasan

Majemuk dan Motivasi Belajar. Seminar Nasional Fisika V (SiNaFi 5.0),

Universitas Pendidikan Indonesia (UPI). DOI:

https://dx.doi.org/10.35542/osf.io/m7n95

Setiawan, Adib Rifqi. (2019, October 02). Efektivitas Pembelajaran Biologi Berorientasi Literasi Saintifik. Thabiea : Journal of Natural Science Teaching, 02 (02): 83-94. DOI: http://dx.doi.org/10.21043/thabiea.v2i2.5345

Setiawan, Adib Rifqi. (2019, October 05). Menyusun Instrumen Penilaian untuk Pembelajaran Ekologi Berorientasi Literasi Saintifik. Seminar Nasional \& Workshop Biologi, IPA, dan Pembelajarannya ke-4 (SnoWBel IV), Universitas Negeri Malang (UM). DOI: https://dx.doi.org/10.13140/RG.2.2.21931.39206

Setiawan, Adib Rifqi. (2019, October 14). Penyusunan Program Pembelajaran Biologi Berorientasi Literasi Saintifik. Seminar Nasional Sains \& Entrepreneurship VI (SNSE VI): 255-1-8. URL:

http://conference.upgris.ac.id/index.php/snse/article/view/255

Setiawan, Adib Rifqi. (2019, October 8). Biografi Clara Ng Perempuan Penulis Asal Indonesia. PsyArXiv. DOI: https://doi.org/10.31234/osf.io/yk8sx

Setiawan, Adib Rifqi. (2019, September 30). Instrumen Penilaian untuk Pembelajaran Ekologi Berorientasi Literasi Saintifik. Assimilation: Indonesian Journal of Biology Education, 02(02): 42-46. DOI: https://dx.doi.org/10.17509/aijbe.v2i2.19250

Setiawan, Adib Rifqi. (2020, April 1). Sharifah Halimah Alaydrus. Thesis Commons. DOI: https://doi.org/10.31237/osf.io/fp79c

Setiawan, Adib Rifqi. (2020, April 1). Syarifah Halimah Alaydrus. Thesis Commons. DOI: https://doi.org/10.31237/osf.io/xbmcs

Setiawan, Adib Rifqi. (2020, April 13). Commodification of the Sexuality in Kim Kardashian's Instagram Posts. Thesis Commons. URL: https://thesiscommons.org/mf7nw/

Setiawan, Adib Rifqi. (2020, April 13). مبادئ اللغة العربية. Thesis Commons. DOI: https://doi.org/10.31237/osf.io/2gvjf

Setiawan, Adib Rifqi. (2020, April 14). Commodification of the Sexuality in Kim Kardashian's Instagram Posts. SocArXiv. DOI: https://doi.org/10.31235/osf.io/kd6au

Setiawan, Adib Rifqi. (2020, April 14). Jalāl al-Dīn 'Abd al-Roḥmān ibn Abī Bakr al-Suyūṭī. SocArXiv. DOI: https://doi.org/10.31235/osf.io/5zf9v 
Setiawan, Adib Rifqi. (2020, April 18). Musyāfahah al-Qur’ān Melalui Media Elektronik. Thesis Commons. URL: https://thesiscommons.org/ntjp9/

Setiawan, Adib Rifqi. (2020, April 2). Desain Pembelajaran untuk Membimbing Siswa Sekolah Dasar dalam Memperoleh Literasi Saintifik. EdArXiv. DOI: https://doi.org/10.35542/osf.io/u59f8

Setiawan, Adib Rifqi. (2020, April 2). JUPE My Uncut Story. Open Science Framework (OSF). DOI: https://doi.org/10.31219/osf.io/qdxga

Setiawan, Adib Rifqi. (2020, April 2). What is the Best Way to Analyze Pre-Post Data?. EdArXiv. DOI: https://doi.org/10.35542/osf.io/h4e6q

Setiawan, Adib Rifqi. (2020, April 20). Menyusun Instrumen Penilaian untuk Pembelajaran Ekologi Berorientasi Literasi Saintifik. Prosiding Seminar Nasional dan Workshop Biologi-IP A dan Pembelajaran Ke-4 (SnoWBel IV): 241-9. ISBN : 978-602-470-1703 \& e-ISBN : 978-602-470-171-0.

Setiawan, Adib Rifqi. (2020, April 21). Lembar Kegiatan Literasi Saintifik untuk Pembelajaran Jarak Jauh Topik Penyakit Coronavirus 2019 (COVID-19). Edukatif: Jumal Ilmu Pendidikan, 02(01): 28-37. DOI: https://doi.org/10.31004/edukatif.v2i1.80

Setiawan, Adib Rifqi. (2020, April 3). Sharifah Halimah Alaydrus : a female preachers for our time. SocArXiv. DOI: https://doi.org/10.31235/osf.io/zb8qe

Setiawan, Adib Rifqi. (2020, April 4). Grace Natalie Louisa. SocArXiv. DOI: https://doi.org/10.31235/osf.io/zwf6g

Setiawan, Adib Rifqi. (2020, April 4). Grace Natalie Louisa. Thesis Commons. DOI: https://doi.org/10.31237/osf.io/u3mxv

Setiawan, Adib Rifqi. (2020, April 5). The Arrogant One. Thesis Commons. DOI: https://doi.org/10.31237/osf.io/8nmku

Setiawan, Adib Rifqi. (2020, April 9). Islamic Education in Southeast Asia. EdArXiv. DOI: https://doi.org/10.35542/osf.io/dnjqv

Setiawan, Adib Rifqi. (2020, April 9). Islamic Education in Southeast Asia. Thesis Commons. DOI: https://doi.org/10.31237/osf.io/e794d

Setiawan, Adib Rifqi. (2020, February 18). Menyusun Instrumen Penilaian untuk Pembelajaran Topik Lingkungan Berorientasi Literasi Saintifik. Prosiding Seminar Nasional Fisika (SiNaFi) 2019: 15-21. URL:

http://proceedings.upi.edu/index.php/sinafi/article/view/563

Setiawan, Adib Rifqi. (2020, January 17). Penerapan Pendekatan Saintifik dalam Pembelajaran Biologi sebagai Upaya Melatih Literasi Saintifik. Prosiding Seminar Nasional Biologi 2019 Inovasi Penelitian dan Pembelajaran Biologi III (IP2B III): 140-145. URL: http://semnasbiologi.conference.unesa.ac.id/ocs/index.php/semnasbio/IP2BII I/paper/viewFile/6/19

Setiawan, Adib Rifqi. (2020, January 17). Penggunaan Mabadi 'Asyroh dalam Pembelajaran Biologi untuk Meningkatkan Motivasi dan Hasil Belajar. Prosiding Seminar Nasional Biologi 2019 Inovasi Penelitian dan Pembelajaran Biologi III (IP2B III): 158164. URL:

http://semnasbiologi.conference.unesa.ac.id/ocs/index.php/semnasbio/IP2BII I/paper/viewFile/11/21

Setiawan, Adib Rifqi. (2020, January 17). Upaya Meningkatkan Motivasi Belajar dalam Pembelajaran Ilmu Pengetahuan Alam (IPA) Melalui Bacaan Populer. Prosiding Seminar Nasional Biologi 2019 Inovasi Penelitian dan Pembelajaran Biologi III (IP2B III): 154-157. URL:

http://semnasbiologi.conference.unesa.ac.id/ocs/index.php/semnasbio/IP2BII I/paper/viewFile/5/51 
Setiawan, Adib Rifqi. (2020, January 24). Pembelajaran Tematik Berorientasi Literasi Saintifik. Jurnal Basicedu: Journal of Elementary Education, 04(01): 71-80. URL: https://jbasic.org/index.php/basicedu/article/view/298

Setiawan, Adib Rifqi. (2020, March 01). Pendidikan Literasi Finansial Melalui Pembelajaran Fiqh Mu'āmalāt Berbasis Kitab Kuning. Ną̧hruna: Jurnal Pendidikan Islam, 03(01): 138-159. DOI: https://dx.doi.org/10.31538/nzh.v3i1.522

Setiawan, Adib Rifqi. (2020, May 12). Introducing the Indonesian Education System. Thesis Commons. DOI: https://doi.org/10.31237/osf.io/ygt5c

Setiawan, Adib Rifqi. (2020, May 6). Discovering the Meaning of Fadhilaturrahmi's Work. Thesis Commons. DOI: https://doi.org/10.31237/osf.io/krf7z

Setiawan, Adib Rifqi. (2020, May 6). Menyibak Makna Karya Fadhilaturrahmi. LIS Scholarship Archive. DOI: https://doi.org/10.31229/osf.io/65y4z

Setiawan, Adib Rifqi; \& Ilmiyah, Surotul. (2020, April 13). Kecerdasan Majemuk Berdasarkan Neurosains. EdArXiv. DOI: https://doi.org/10.35542/osf.io/rj2fe

Setiawan, Adib Rifqi; \& Ilmiyah, Surotul. (2020, April 13). Multiple Intelligences Based on Neuroscience. Thesis Commons. DOI: https://doi.org/10.31237/osf.io/e9fyu

Setiawan, Adib Rifqi; \& Ilmiyah, Surotul. (2020, April 7). Lembar Kegiatan Siswa untuk Pembelajaran Jarak Jauh Berdasarkan Literasi Saintifik pada Topik Penyakit Coronavirus 2019 (COVID-19). EdArXiv. DOI: https://doi.org/10.35542/osf.io/h4632

Setiawan, Adib Rifqi; Mufassaroh, Arij Zulfi. (2019, June 28). Menyusun Soal Literasi Saintifik untuk Pembelajaran Biologi Topik Plantae dan Animalia. BIOSFER: Jurnal Biologi dan Pendidikan Biologi, 04(01): 33-40. URL: http://dx.doi.org/10.23969/biosfer.v4i1.1484

Setiawan, Adib Rifqi; Puspaningrum, Mita; Umam, Khoirul. (2019, December 06). Pembelajaran Fiqh Mu'āmalāt Berorientasi Literasi Finansial. Tarbany: Indonesian Journal of Islamic Education, 06(02): 187-102. URL: https://ejournal.upi.edu/index.php/tarbawy/article/view/20887

Setiawan, Adib Rifqi; Saputri, Wahyu EKa. (2020, December 10). Pembelajaran Literasi Saintifik untuk Pendidikan Dasar. Media Penelitian Pendidikan : Jurnal Penelitian dalam Bidang Pendidikan dan Pengajaran, 14(02). DOI: https://doi.org/10.26877/mpp.v14i2.5794

Setiawan, Adib Rifqi; Saputri, Wahyu EKa. (2020, June 13). Science Motivation Questionnaire II (SMQ II) Versi Bahasa Indonesia. Psy ArXiv. DOI: https://doi.org/10.31234/osf.io/tac2k

Setiawan, Adib Rifqi; Utari, Setiya; Nugraha, Muhamad Gina. (2016, December 17). Mengonstruksi Rancangan Soal Domain Kompetensi Literasi Saintifik Siswa SMP Kelas VIII pada Topik Gerak Lurus. Seminar Nasional Fisika ke-2 (SiNaFi II), Universitas Pendidikan Indonesia (UPI). DOI: https://dx.doi.org/10.13140/RG.2.2.31856.10246/1

Setiawan, Adib Rifqi; Utari, Setiya; Nugraha, Muhamad Gina. (2017, September 22). Mengonstruksi Rancangan Soal Domain Kompetensi Literasi Saintifik Siswa SMP Kelas VIII pada Topik Gerak Lurus. Wabana Pendidikan Fisika, 02(02): 44 48. URL: https:// ejournal.upi.edu/index.php/WPF/article/view/8277/0

Siayah, Syarofis; \& Setiawan, Adib Rifqi. (2020, April 13). A Brief Explanation of Science Education. EdArXiv. DOI: https://doi.org/10.35542/osf.io/2evn3

Siayah, Syarofis; \& Setiawan, Adib Rifqi. (2020, April 13). A Brief Explanation of Science Education. Thesis Commons. DOI: https://doi.org/10.31237/osf.io/wkvsn Velasufah, Whasfi; \& Setiawan, Adib Rifqi. (2020, April 13). Nilai Pesantren Sebagai Dasar Pendidikan Karakter. Thesis Commons. DOI: https://doi.org/10.31237/osf.io/hq6kz 
